\title{
STREAMFLOWS IN WYOMING
}

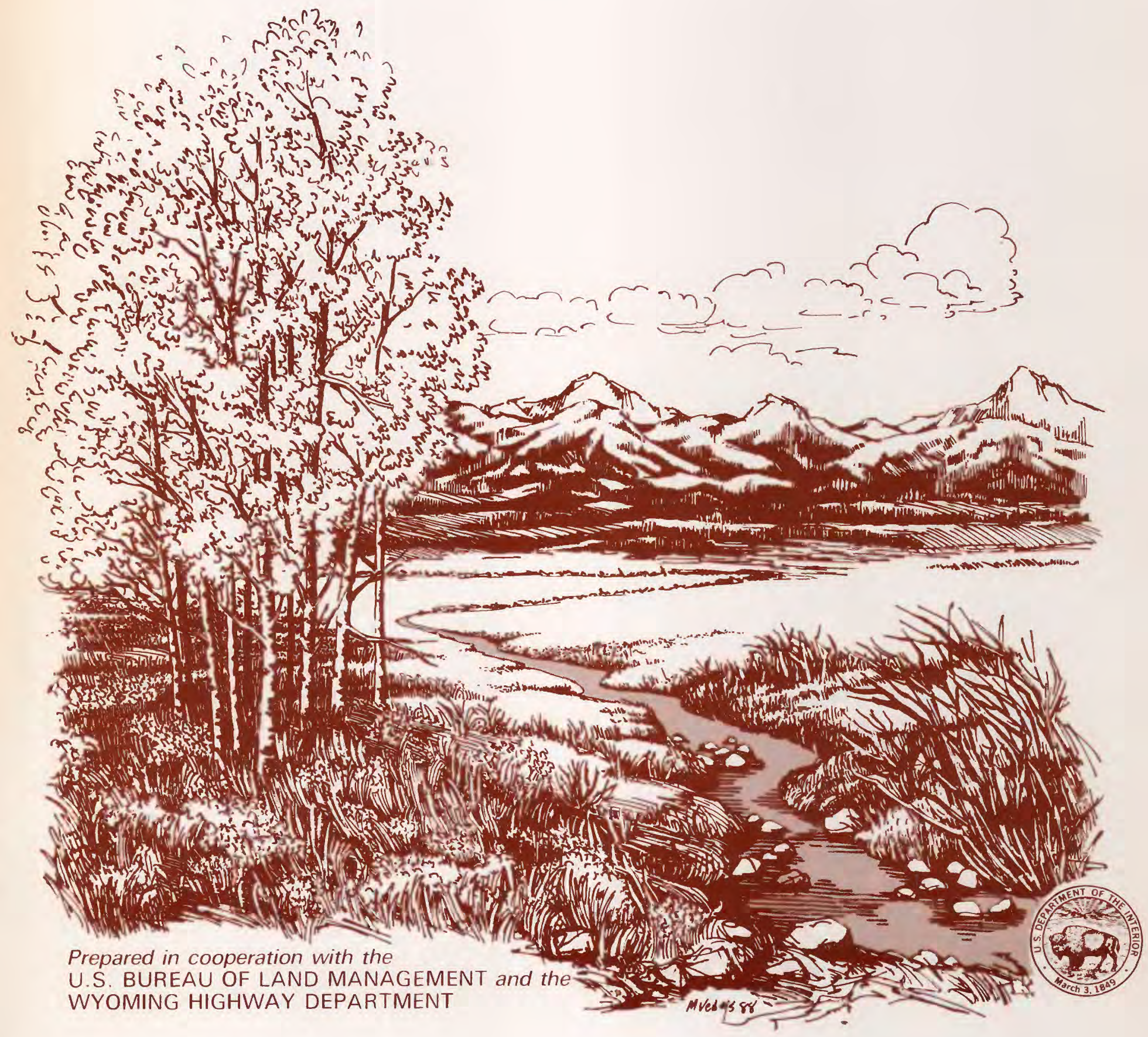


STREAMFLOWS IN WYOMING

By H.W. Lowham

U.S. GEOLOGICAL SURVEY

Water-Resources Investigations Report 88-4045

Prepared in cooperation with the

U.S. BUREAU OF LAND MANAGEMENT and the

WYOMING HIGHWAY DEPARTMENT

Cheyenne, Wyoming

1988

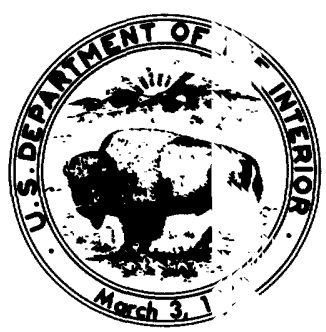


DEPARTMENT OF THE INTERIOR

DONALD PAUL HODEL, Secretary

U.S. GEOLOGICAL SURVEY

Dallas L. Peck, Director

\begin{tabular}{|c|c|}
\hline $\begin{array}{l}\text { For additional information } \\
\text { write to: }\end{array}$ & $\begin{array}{l}\text { Copies of this report can be } \\
\text { purchased from: }\end{array}$ \\
\hline $\begin{array}{l}\text { District Chief } \\
\text { U.S. Geological Survey } \\
2120 \text { Capitol Avenue } \\
\text { P.O. Box } 1125 \\
\text { Cheyenne, WY } 82003\end{array}$ & $\begin{array}{l}\text { U.S. Geological Survey } \\
\text { Books and Open-File Reports Sertion } \\
\text { Federal Center, Bldg. } 810 \\
\text { Box } 25425 \\
\text { Denver, Co } 80225\end{array}$ \\
\hline
\end{tabular}




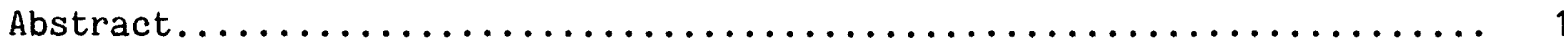

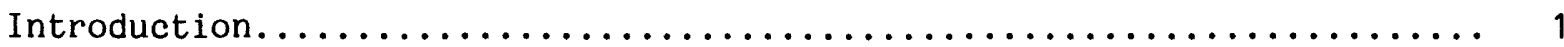

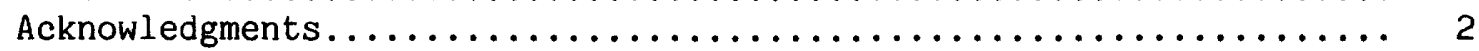

History of surface-water development in Wyoming.............. 2

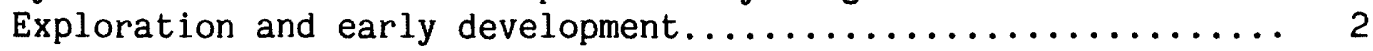

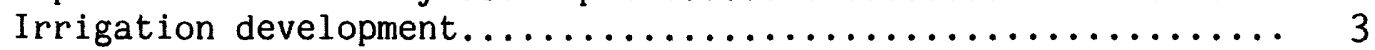

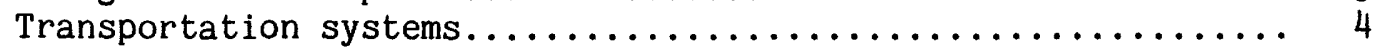

Energy development and urbanization................... 5

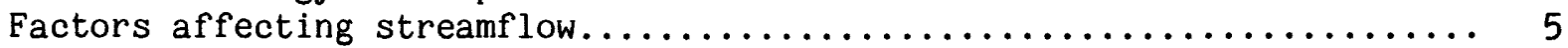

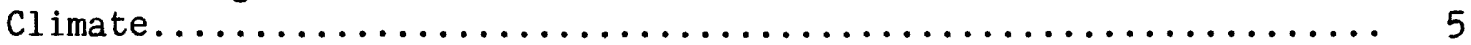

Surficial geology and soils............................ 9

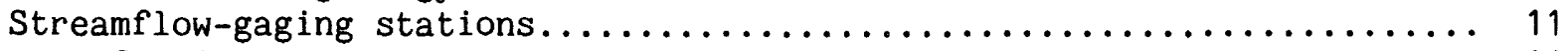

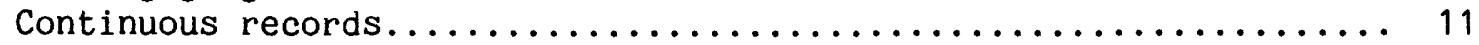

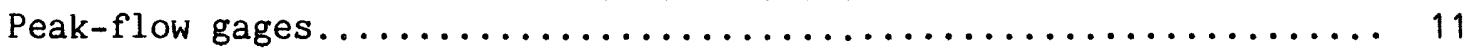

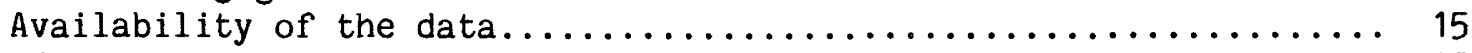

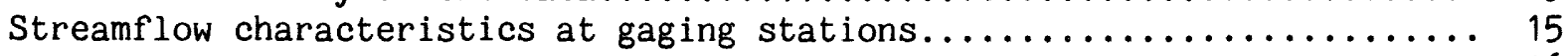

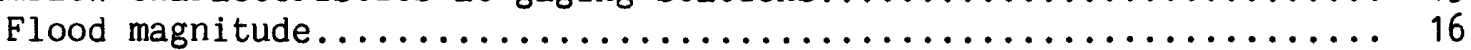

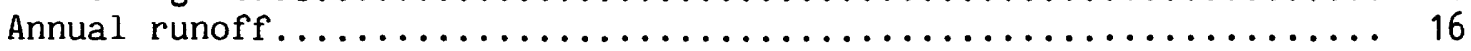

Estimation of streamflow characteristics at ungaged sites........... 16

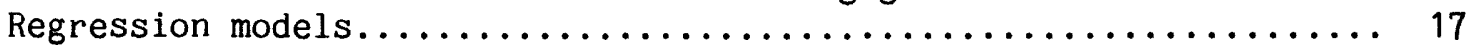

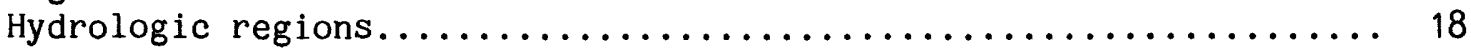

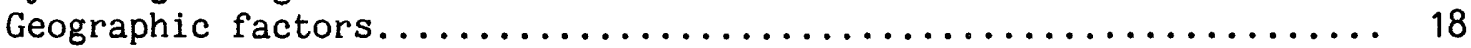

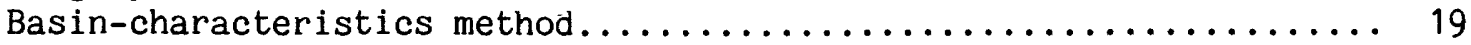

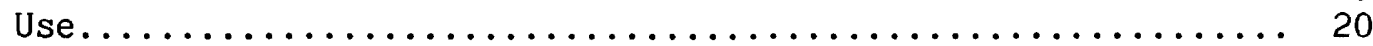

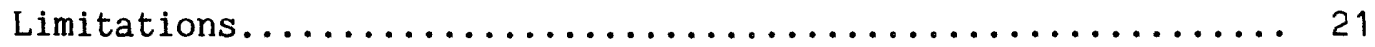

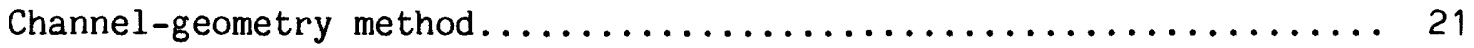

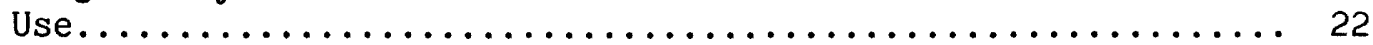

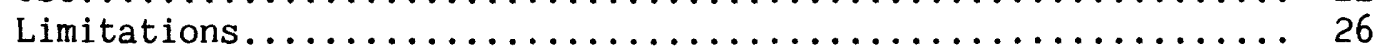

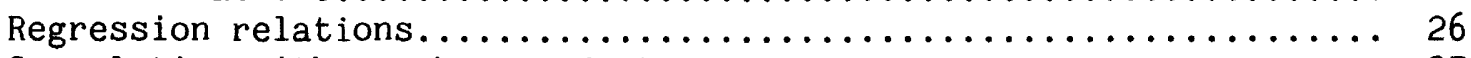

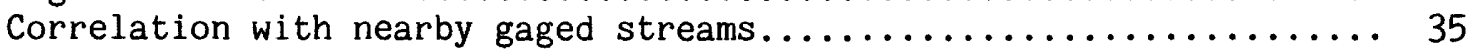

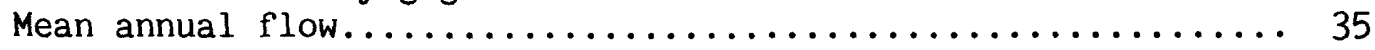

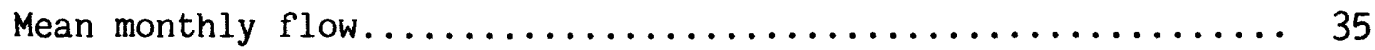

Flood characteristics at gaged sites with short records.......... 35

Example applications............................. 36

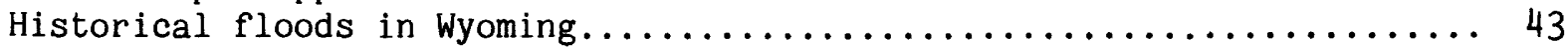

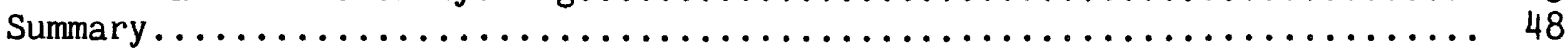

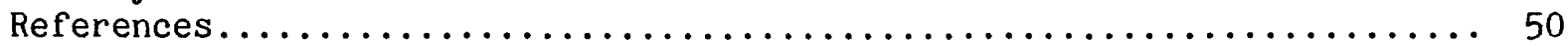


PLATE

Plate 1. Maps showing hydrologic regions on landsat image mosaic, average annual precipitation, location of streamflowIn gaging stations, and geographic factors in Wyoming.......... Pocket

\section{FIGURES}

Page

Figure 1. Hydrograph showing daily discharge for Fontenelle Creek, which drains a mountainous area in

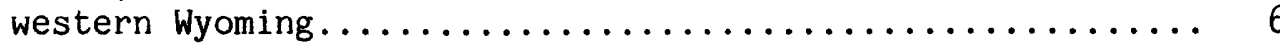

2. Hydrograph showing daily discharge for East Fork Nowater Creek, which drains a plains area in

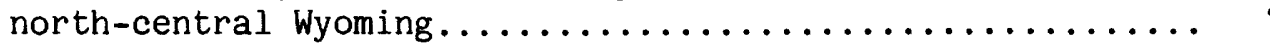

3. Graph showing comparison of annual precipitation and

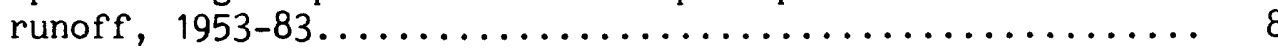

4. Graph showing normal monthly precipitation at selected

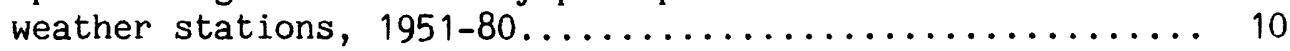

5. Sketch showing discharge being measured from a cableway..... 12

6 . Sketch showing procedure for collection of streamflow

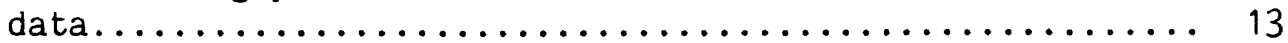

7. Photograph showing how peak stages of floods are recorded by a crest-stage gage.................... 14

8. Sketch showing cross sections of various types of stream channels where width should be measured.............. 23

9-12. Photographs:

9. Tape and stakes show where channel width was measured on North Fork Crazy Woman Creek near Buffalo.................................... 24

10. Tape and stakes show where channel width was measured on Cache Creek near Jackson .............. 24

11. Tape and stakes show where channel width was measured on Sand Springs Draw near Pinedale......... 25

12. Rod and stakes show where channel width was measured on tributary to the New Fork River near

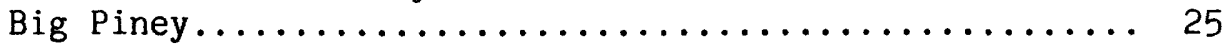

13. Map showing drainage basin for tributary of Shawnee Creek near Douglas.......................... 38

14. Graph showing relation of peak discharge to drainage area for the Bear River........................ 42

15. Photograph showing Dry Creek in north Cheyenne the day after the flood of August 1, 1985.............. 44

16. Photograph showing hail accumulation in a low area of Cheyenne following the flood of August 1, 1985........ 44

17-19. Graphs showing the relation of maximum known peak discharge to drainage area for the:

17. Mountainous Regions....................... 45

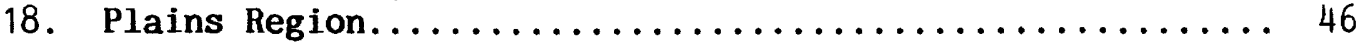

19. High Desert Region......................... 47 


\section{TABLES}

1. Summary of regression relations for estimating peak-flow characteristics and mean annual flow of streams in the Mountainous Regions.............................. 27

2. Summary of regression relations for estimating peak-flow characteristics of streams in the Plains Region............. 30

3. Summary of regression relations for estimating peak-flow characteristics of streams in the High Desert Region.......... 32

4. Summary of regression relations for estimating mean annual

flow of streams in the Plains and High Desert Regions.......... $3^{\text {ll }}$

5. Applicable range of the estimation relations .................. $3^{\prime}$

6. Summary of data and results for estimating mean monthly

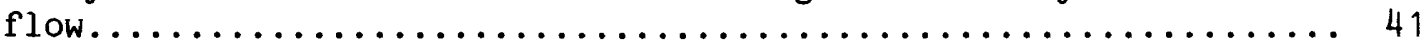

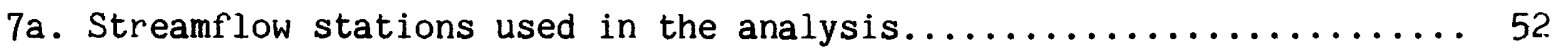

7b. Streamflow characteristics at gaged sites.................. 60

7 c. Basin characteristics and channel width................... 71 
For the convenience of readers who may prefer to use metric (International System) units rather than the inch-pound units used in this report, values may be converted by using the following factors:

$\begin{array}{lll}\text { Multiply } & \frac{\text { By }}{\text { Mo obtain }} \\ \text { cubic foot per second } & 0.02832 & \text { cubic meter per second } \\ \text { foot } & 0.3048 & \text { meter } \\ \text { foot per mile } & 0.1894 & \text { meter per kilometer } \\ \text { inch } & 2.54 & \text { centimeter } \\ \text { mile } & 1.609 & \text { kilometer } \\ \text { square mile } & 2.590 & \text { square kilometer } \\ & & \\ \text { Sea level: In this report, "sea level" refers to the National Geodetic } \\ \text { Vertical Datum of 1929 (NGVD of 1929)--a geodetic datum derived from a general } \\ \text { adjustment of the first-order level nets of both the United States and Canada, } \\ \text { formerly called "Mean Sea Level of 1929." }\end{array}$




\title{
STREAMFLOWS IN WYOMING
}

\author{
by H.W. Lowham
}

\begin{abstract}
A description of the occurrence and variability of surface waters in Wyoming is presented along with explanations of both streamflowdata collection and methods for estimating streamflow characteristics at gaged and ungaged sites. Mountain ranges separate the major drainage basins and have a significant effect on precipitation and runoff that occur in Wyoming. Streams that originate in the mountains provide the most dependable source of runoff; streams that originate in the plains and deserts generally have extended periods of no flow.

Streamflow data for several hundred gaged sites in the State are available for engineering and management purposes. When gaged data are not available, methods for estimating flows are needed. Methods presented in this report for estimating streamflow characteristics have been developed through the use of refined analytical techniques and an updated data base.

Peak-flow characteristics and mean annual flow at ungaged sites can be estimated by using regression equations, with either basin characteristics or channel width as independent variables. Loglinear regression equations are used for depicting streamflow characteristics in the mountains. Curvilinear equations of doubleexponential form were determined to be more appropriate than loglinear equations for depicting peak flows in the plains and deserts.

Regression relations were determined to be unsuitable for estimating mean monthly streamflows. Because of geographical differences in runoff patterns, data for streamflow gages near the ungaged site can be used to estimate mean monthly flows. The procedure requires an estimate of mean annual flow, with mean monthly flow determined as a percentage of mean annual flow from records of nearby gaged sites.
\end{abstract}

\section{INTRODUCTION}

Water is one of the most basic and essential of our resources, and surface waters are the main source of water used in Wyoming. The occurrence and availability of surface waters vary greatly throughout the State partly due to the effect that mountain ranges have on the quantity of precipitation and resulting runoff. Although several major rivers flow across the plains and desert areas of the State, the main source of perennial flow in these rivers is from snowmelt in the mountains. Information concerning streamflows, including floodflows, is needed to plan and design irrigation projects, roads, bridges, and other stream-related developments. 
This report is the product of several technical investigations of streamflows in Wyoming. The investigations were done by the U.S. Geological Survey in cooperation with the U.S. Bureau of Land Management and the Wyoming Highway Department, to provide streamflow information needed for land-use planning and for design of stream-related developments. This report presents: (1) A history of surface-water use and developments affected by surface water, (2) an explanation of factors affecting streamflow, (3) a description of record collection at sites having streamflow-gaging stations, and information on how users may obtain these records, (4) a description of improved methods for estimating streamflow characteristics at ungaged sites, and (5) a summary of historical floods.

\section{Acknowledgments}

The assistance of A. Mainard Wacker, Hydraulics Engineer, Wyoming Highway Department, and W.O. Thomas, hydrologist, Office of Surface Water, U.S. Geological Survey, in developing an improved regression model for depicting peak-flow characteristics in the plains and desert areas of wyoming is gratefully acknowledged. Mr. Wacker and his staff observed that equations from previous reports did not adequately depict peak-flow characteristics over a complete range of drainage sizes, and they suggested that an improved model was needed. The applicability of a double-exponential equation was suggested by Mr. Thomas, who assisted the author with the development and computer programming of the curvilinear model. The contributions of $\mathrm{Mr}$. Wacker and $\mathrm{Mr}$. Thomas are greatly appreciated.

\section{History of Surface-Water Development in Wyoming}

\section{Exploration and Early Development}

A group of Spaniards may have been the first explorers, other than the native Indians, to venture into what is now Wyoming. On the basis of scant evidence, historian C.G. Coutant (1899a, p. 23) concluded that one of numerous Spanish expeditions from Mexico traveled as far north as the Missouri River and explored the Yellowstone country during the sixteenth or severteenth century.

During 1807-08, John Colter explored the headwaters of the Yellcistone and Snake Rivers in northwestern Wyoming while attempting to establish a fur trade with the Indians. This exploration opened up a significant fur trade that flourished from 1823 through the $1830^{\prime}$ s. Gold miners were next to explore streams of the unknown West. The first discovery of gold in Wyoming was in 1842 along the Sweetwater River (Coutant, 1899b, p. 637-674); this stimulated further exploration and discoveries in other areas.

Trappers and miners led the way to the West and were fundamental to the exploration of the territories; however, the largest number of settlers were drawn by the promise of land ownership and the opportunities of agriculture. "Go West, young man, go West," was the advice given to young Americans in the mid-1800's. The choice land in the East had been settled, and the greatest opportunity for ambitious persons was in the western territories of arundant land and resources. 
Thousands of emigrants passed through the Wyoming Territory during 184090. Some of them stayed and settled, and the prime croplands along flowing streams were soon claimed. This did not deter the emigrants. "Where the plow goes, the rain will follow," was a notion that was popular among developers and hopeful pioneers when the West was being opened for settlement (Smith, 1947). Many residents of the East actually believed that God or nature would provide rain to fields that were cultivated in arid western lands. Unfortunately, hundreds of settlers lost their life savings or their lives before the notion was abandoned.

Streams were used during the development of the West for the transporting of timber. The building of the transcontinental railroad in 1867 spurred the timber industry to meet the need for railroad ties in the construction and maintenance of the railroad, and also for timbers used in the mines that supplied coal to the railroad. Because the railroad was built mainly across flat areas of the plains and deserts, streams--such as the Laramie, North Platte, Green, and Bear Rivers--that flowed from the mountains to the railrcad were used whenever possible to transport the timber.

Some early pioneers and technical persons, who were cautious about fullscale opening of western lands, advised Congress and developers of the realities new settlers might incur (Stegner, 1960). Major John Wesley Powell, one of the most knowledgeable experts on the resources of the West, gaired firsthand knowledge of the West and its water resources from expeditions made in 1869 and 1872 down the Colorado River. These expeditions began on the Green River in Wyoming. On the basis of his field investigations, Powell (1878) stated that much of the West was arid grazing land, of value only wren used in large quantities. His opinion was that most of the prime and easilyirrigable lands along streams had already been settled. Powell drew uf a bill stipulating that new ranches on the remaining lands should be no less than 2,560 acres, but Congress did not pass it (Stegner, 1960, p. 239).

However, in 1877, Congress did pass the Desert Land Act that allowed homesteading of certain 640-acre tracts requiring irrigation in order to raise a crop. Water commonly was not available, and only about a quarter of the filings resulted in patents. The Carey Act, passed by Congress in 18c?, transferred land to the states. The states could then grant water rights for 160-acre blocks. After blocks had been settled upon and cultivated, clear title was then granted. Wyoming adopted this plan in 1894.

\section{Irrigation Development}

The main use of water in Wyoming is for irrigation. Although growing seasons are sufficient for many crops at lower elevations in Wyoming, the successful growing of these crops generally requires irrigation because precipitation is usually small and unpredictable. Irrigated grass hay larts and pastures constitute a large use of water along streams in Wyoming. Snowmelt from the mountains is the main source of streamflow in the many streams and rivers used for irrigation. Irrigated areas and mountaincus regions in Wyoming are highlighted on plate 1a (at back of report), which is a mosaic of infrared imagery taken from a Landsat satellite. The imagery uses false colors that distinctly show certain features, such as vegetation and bedrock. 
Exactly when the first irrigation began in Wyoming is subject to debate. Historian David J. Wasden (1973, p. 153-154) presents evidence that the first irrigation ditch in what is now Wyoming may have been constructed along the Hams Fork in the 1830 's by a colony of Mexican settlers.

A number of successful irrigation projects were developed by Mormon settlers, who were noted for their irrigation knowledge. A group of Mormons journeyed from Salt Lake City to establish an agricultural settlement known as Fort Supply on the Smiths Fork in 1853 (plate 1a). Fort Supply was ].ater abandoned, but other irrigation projects were developed, including some in the Star Valley and the Bighorn Basin.

Most irrigation began as diversion of natural flows. As develonment flourished, it was realized that storage was needed to supply water through the complete irrigation season. Landowners subsequently organized and formed development companies to construct and operate reservoirs (Frank J. Trelease, I I , Assistant State Engineer for Wyoming, oral commun., 1987). For example, Wyoming Development Company Reservoir No. 1, with a storage capacity of 5,360 acre-feet, was constructed in 1897 as an of $f$-channel reservoir of Sybille Creek, a tributary of the Laramie River. The project was successful, and the development company was changed to an irrigation district. After filing for water rights in 1898, the district also completed Wheatland No. 2 Reservoir, with a storage capacity of 98,300 acre-feet, on the Laramie River in 1904. Similar efforts of group enterprise were instrumental in the development of successful irrigation throughout Wyoming, especially along smaller and metiumsized streams and rivers.

The Federal Reclamation Act of 1902 authorized Congress to allow the Reclamation Service to begin construction of major projects that would develop streamflow for irrigation and power production. As a result, large dams and reservoirs have been constructed on the North Platte, Wind-Bighorn, Shoshone, Green, and Belle Fourche Rivers. These projects have contributed greatly to the agricultural and industrial economies of Wyoming.

\section{Transportation Systems}

As the agricultural development in the western states progressed, there was a movement by Congress to assist farmers and ranchers in transpcinting their products to market by developing paved roads (A. Mainard Wacker, Hydraulic Engineer, Wyoming Highway Department, oral commun., 1987). The construction of paved highways was greatly expanded during the 1920's and 1930 's. With the development of improved roads, tourism also began to flourish, especially as a result of travel to Yellowstone National Park, the first area set aside in the United States as a national park.

A major consideration in the design of highways is the size of structure needed for stream and river crossings. Before about 1960, engineers with the Wyoming Highway Department used empirical methods to determine structure size. During the $1960^{\prime} \mathrm{s}$, the Department began a program with the U.S. Geolcrical Survey to collect and summarize floodflow data specific to Wyoming. 


\section{Energy Development and Urbanization}

The development of energy minerals, including oil and gas, coal, and uranium, has become a major industry in Wyoming along with agriculture and tourism. Many of the towns and cities in the State have experienced growth and population increases associated with the mineral industry. Information needed by industry regarding surface water generally is for water-supfly purposes and also for design of stream-related structures. Municipalities and land-use agencies, such as the U.S. Bureau of Land Management, also are concerned with water-supply and flood information. Planning associated with floods in urban areas was especially strengthened by the National Flcnd Insurance Act of 1968 (Public Law 90-448) and the closely related Flood Disaster Protection Act of 1973 (Public Law 93-234) (U.S. Water Resources Council, 1979, p. VI-3).

\section{FACTORS AFFECTING STREAMFLOW}

Various types of streams exist in Wyoming due to differences in climate and physical features such as geology. Perennial streams generally origincte in the mountainous areas as a result of significant annual precipitation and geologic conditions that foster ground-water discharge. Streams originating in the semiarid and arid plains and desert areas generally are ephemeral, flowing mainly in direct response to rainstorms and snowmelt.

The major part of annual runoff in streams draining mountainous areas occurs during spring and early summer as a result of snowmelt. A hydrogreph typical of a mountainous stream is shown in figure 1. Streamflow generally peaks during June; however, this varies from year-to-year depending on both local weather conditions and physical features of individual basins. Late summer, fall, and winter flows are largely the result of ground-water inflor's. Minimum streamflows generally occur during January through March. The total runoff that occurs during any particular year is closely related to the precipitation for that year.

Intermittent and ephemeral streams draining the plains and desert areas flow only periodically and often have extended periods of no flow (fig. 2). These streams may receive some ground-water inflows in addition to direct surface runoff; however, the ground-water inflows are insufficient to sustain flow throughout the year. Springs are present in some areas of the plains and deserts, and these springs commonly contribute small perennial inflows to streams. However, losses of water to evaporation, transpiration, and seepage, and storage as ice generally limit the extent of these flows to short reaches downstream from the springs.

\section{Climate}

Streamflows are closely related to climate, especially precipitation (fig. 3). The climate of Wyoming varies greatly with the season and by location due to the effects of altitude and mountain terrain on wind, $a$ ir temperature, and precipitation. The distribution of average annual precipitation is shown on plate $1 \mathrm{~b}$. 


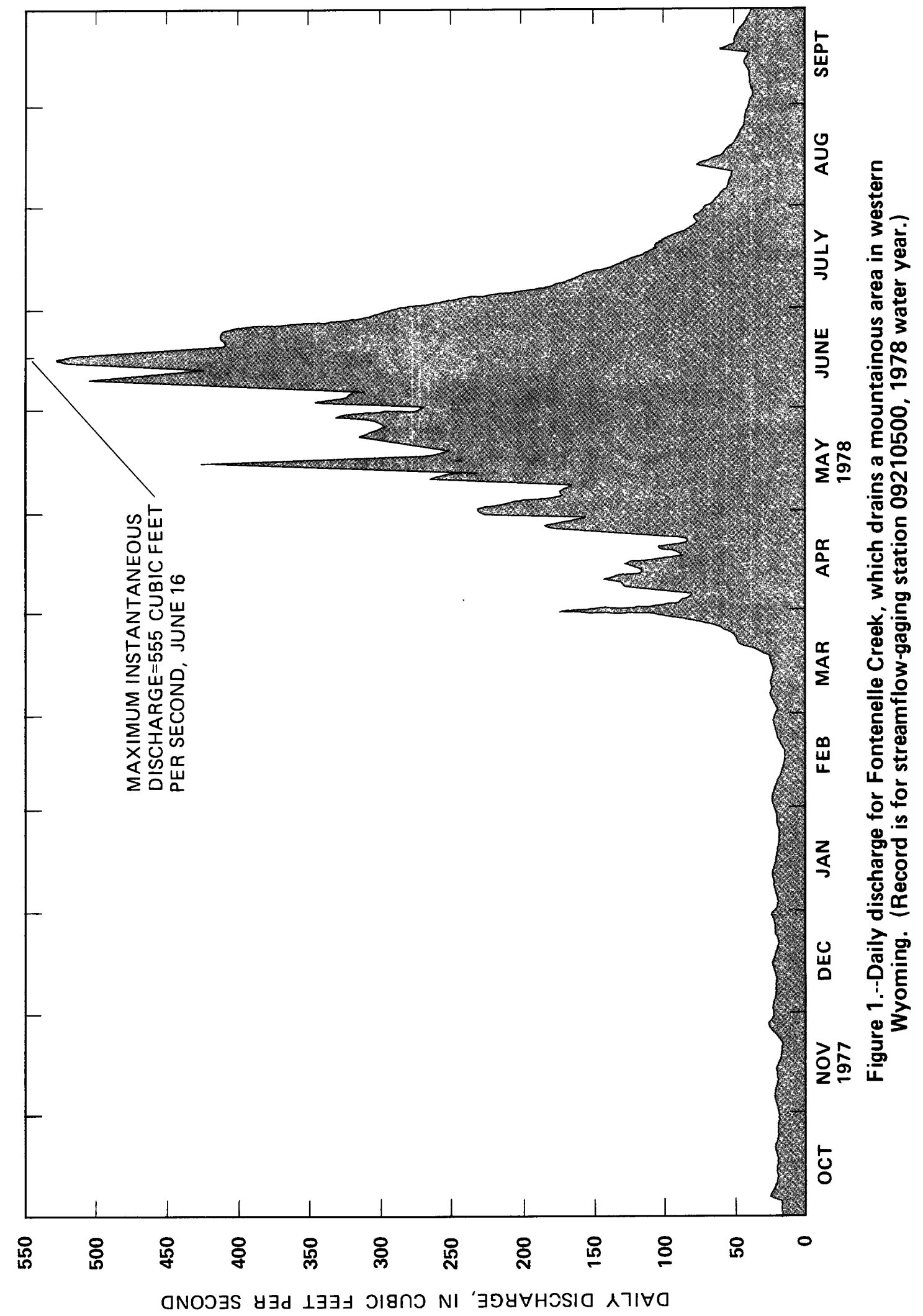




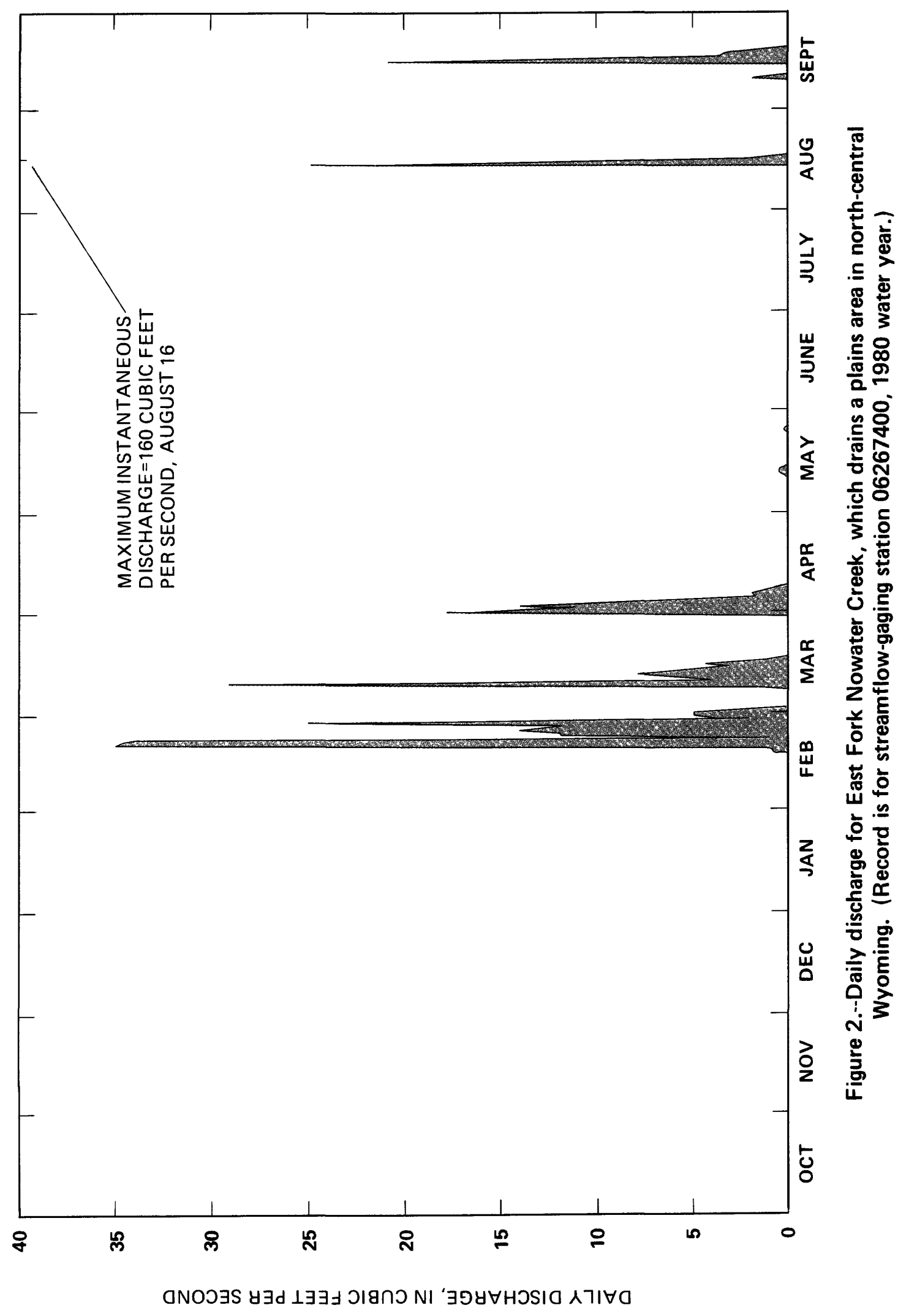




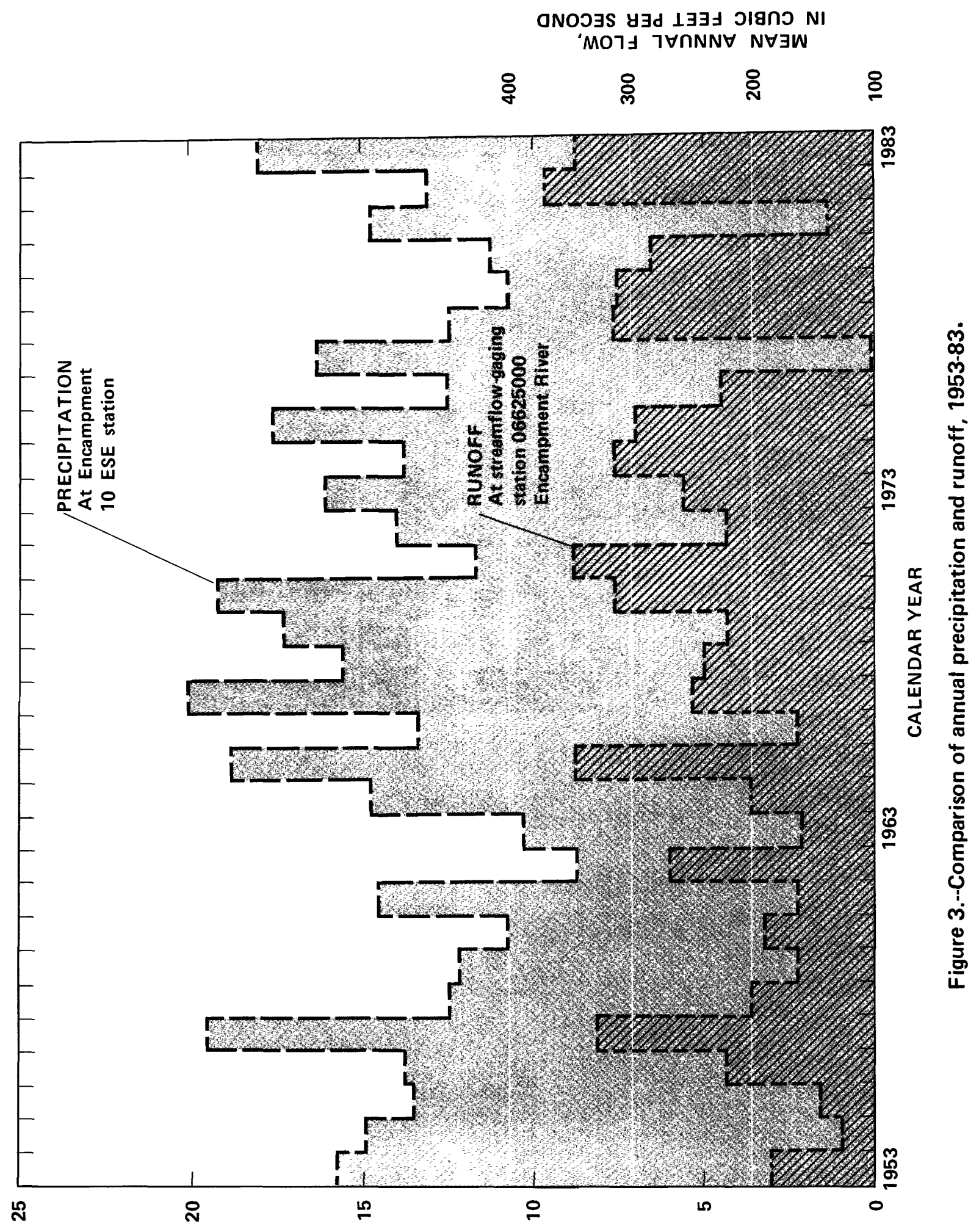

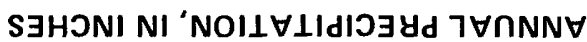


A summary of climate in the state follows. This summary and the precipitation map on plate $1 \mathrm{~b}$ are based on a report prepared by J.D. Alyea (1980) for the U.S Geological Survey.

Maritime airflows from the Pacific Ocean are the source of moisture for most of the annual precipitation in Wyoming. The air masses are borne eastward by the prevailing westerly winds, although coastal mountain ranges cause much of the moisture to precipitate before reaching Wyoming.

Most wintertime precipitation is in the form of snow. Snowstorms with the greatest precipitation occur when cold airflows from the north move into the area and wedge under the warmer surface air; the warm air is forced upward, causing snow. In the mountains, the cold temperatures allow much of the snow to be retained until spring melting. In the interior plains and deserts, much snowfall is quickly sublimated by the wind and sun, and retention occurs mainly as drifts in draws and shaded areas.

Summertime precipitation occurs as light rain and from occasional, intense convective storms that generally move in an easterly direction. T'le warmer atmosphere in spring has increased moisture-carrying capacity, which results in the relatively large quantities of precipitation during April, Mey, and June (fig. 4).

As summer progresses and the atmosphere continues to warm, more moisture is available for precipitation, but the cumulus clouds are formed much higher above the land surface. Precipitation from these clouds has a relatively long path through dry air, and much of it evaporates before reaching the land surface.

Mountain ranges greatly affect the occurrence of precipitation in Wyoming. Precipitation increases with elevation, and the mountainous areas commonly receive 25 inches or more precipitation annually, while the plains and deserts receive as little as 6 or 7 inches.

The precipitation map on plate $1 \mathrm{~b}$ indicates the average annual precipitation that occurs throughout Wyoming. For the plains and desert areas of the State, the percentage of average annual precipitation that occurs during the months of May through September also is shown. During this perict, precipitation in the form of rain or hail generally occurs from convective storms; during the remainder of the year, precipitation generally occurs as light rainfall and snowfall. The percentages infer that precipitation from convective storms is more predominant in the northern and eastern plains than in the southern and central desert areas of the State.

\section{Surficial Geology and Soils}

Surficial geology and soil type affect infiltration and thus hav $\epsilon$ significant effect on streamflow. Generally, coarse-grained surficial materials such as sand and gravel (alluvial and glacial deposits) and sandstone have more rapid infiltration rates than fine-grained materials such as clay, silt, siltstone and shale. However, infiltration rates in some finegrained rocks and limestone are increased by fracturing resulting from geologic movement. Slow infiltration occurs in areas of clayey soils. The rate of infiltration especially affects runoff resulting from snowmelt and 


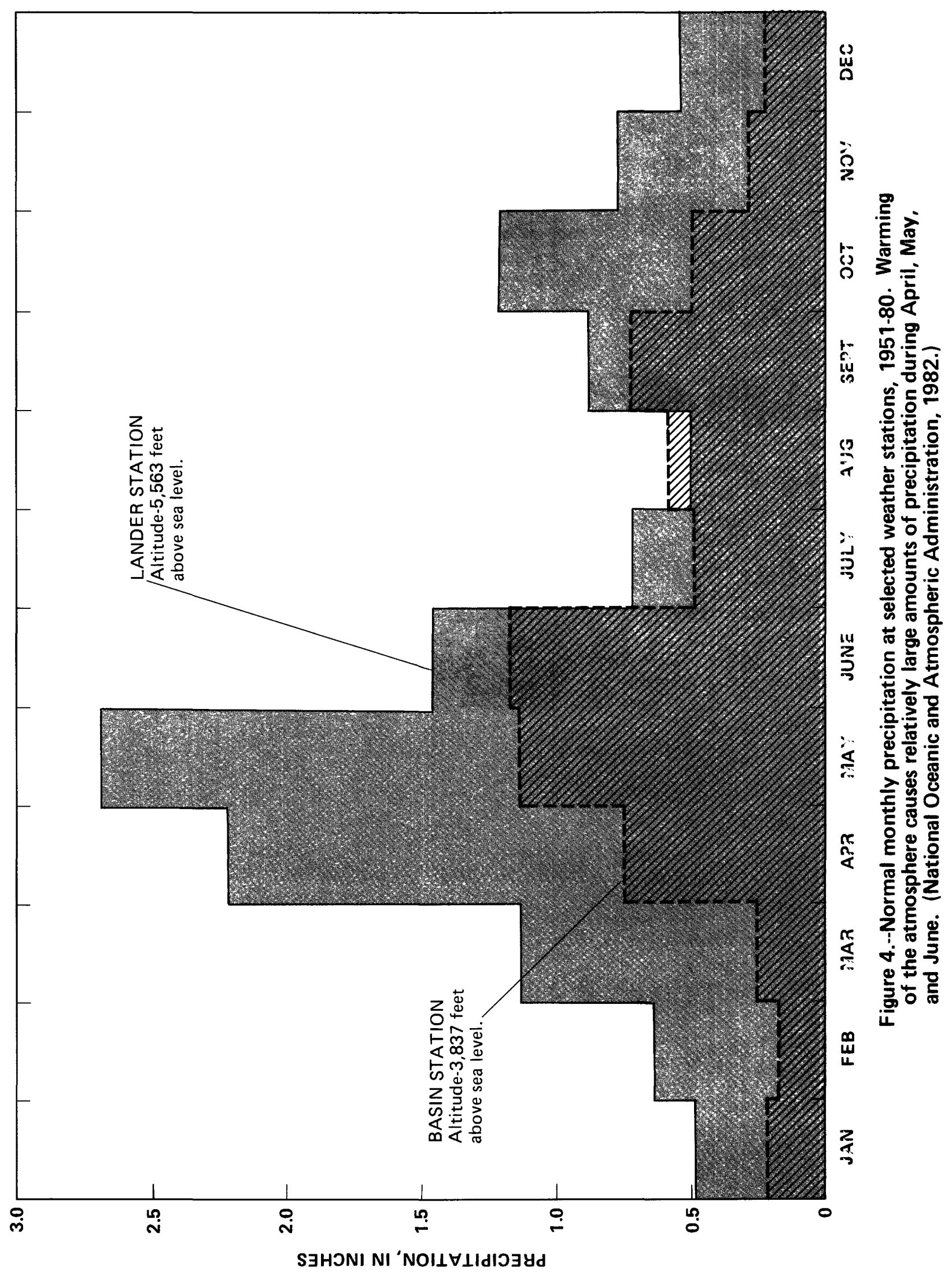


rainstorms of moderate intensity. Intense rainstorms produce runoff that is less affected by infiltration rates than for moderately intense storms because the precipitation and resulting runoff occur very quickly. In addition, for very large storms of high intensity, infiltration is insignificant in affecting runoff because the total precipitation generally is so much greatier than the part of the precipitation that infiltrates into the soil.

\section{STREAMFLOW-GAGING STATIONS}

When the design or management of a development requires streamflow data, a gaging station may be installed. Streamflow-gaging stations have been operated on Wyoming streams since 1888, when the first gage was installed on the Laramie River by the Wyoming Territorial Engineer and the U.S. Geological Survey. Since then, several hundred gages have been operated throughout the State for differing time periods. The majority of gages are operated by the U.S. Geological Survey in cooperation with other Federal and State agencies. Other gages are independently operated by the University of Wyoming, State agencies, the U.S. Soil Conservation Service, and private concerns such as mining companies.

\section{Continuous Records}

A continuous-record station has a recorder whereby a continuous record of stage (water level) is recorded. Using discharge measurements ( $\mathrm{fig}$. 5) made at the site, a relation between stage and discharge (stage-discharge rating) is developed to enable discharge to be determined for any stage of the stream. By combining the rating with the record of stage, a continuous record of stream discharge is determined. This record may be expressed as average daily, monthly, and yearly rates, or volumes of flow. Instantaneous peak flows or total runoff for a particular period also may be determined. A diagram summarizing the procedure for streamflow-data collection is shown in figure 6 . For a comprehensive description of standardized stream-gaging procedures, the reader is referred to U.S. Geological Survey Water-Supply Paper 2175 (Rantz, 1982).

\section{Peak-Flow Gages}

For certain purposes, such as for the design of bridges and culverts, only peak-flow data are needed. A special gage that records the maximum stages of floods is used to collect this type of data (fig. 7).

Visits are made periodically to inspect the gage for high-water marks that may have occurred from intervening floods. The peak discharge for each maximum recorded stage is determined from a stage-discharge rating developed for the site. These gages are often referred to as crest-stage stations (Rantz, 1982, p. 77-79). The amount of equipment and work needed to maintain crest-stage stations are much less than that needed for continuous-record stations; hence, they are less expensive to operate. A statewide network of crest-stage gages was operated during 1959-85 as part of a cooperative program between the Wyoming Highway Department and the U.S. Geological Survey. 


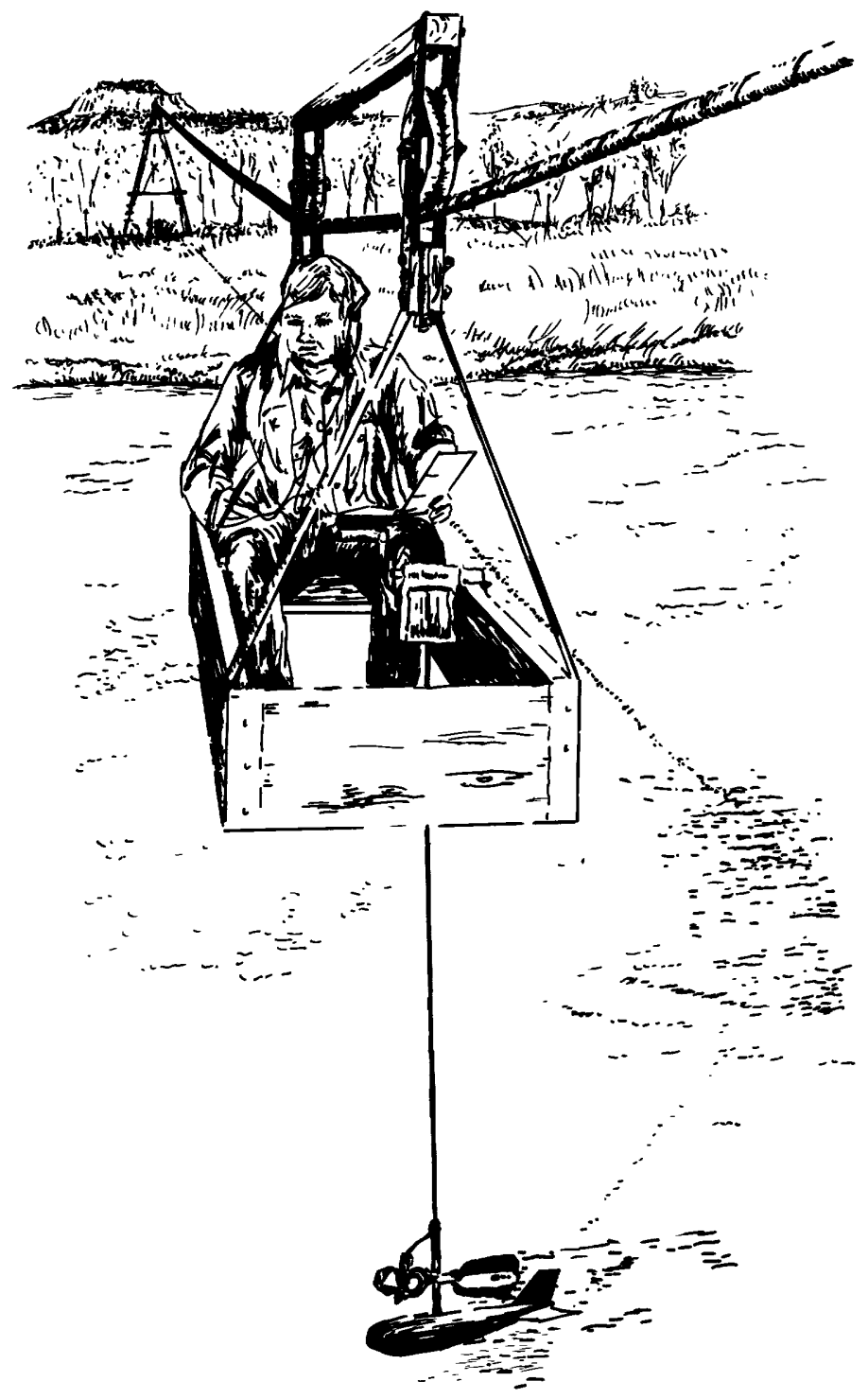

Figure 5.--Discharge being measured from a cableway. 


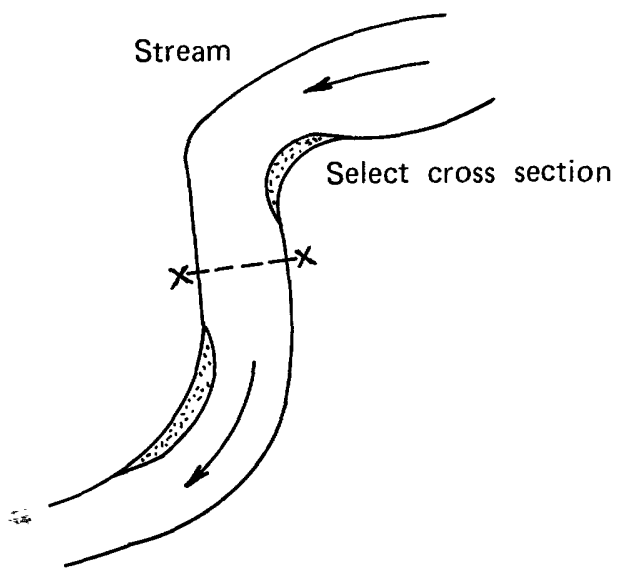

Stage-discharge rating

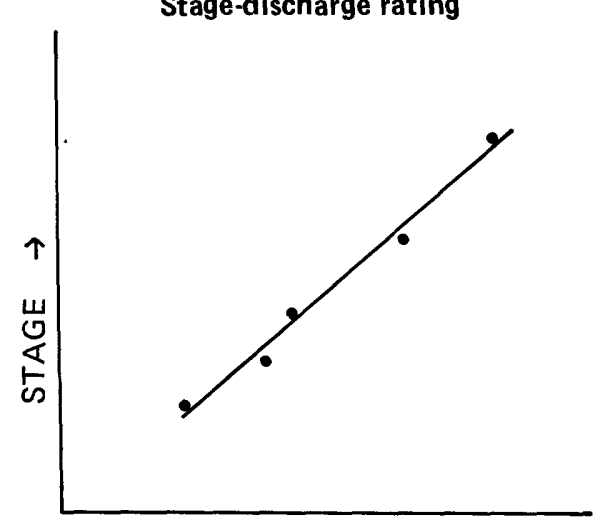

DISCHARGE $\rightarrow$

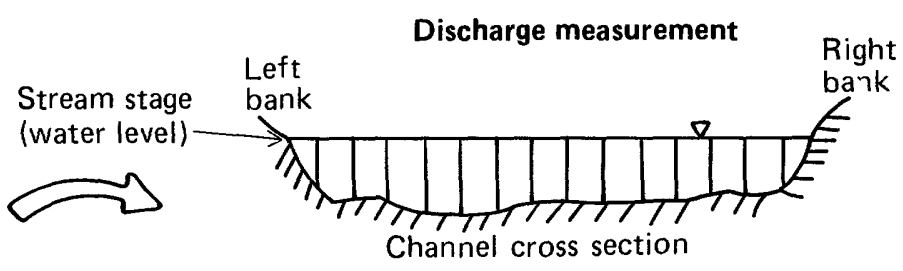

Subdivide cross section and measure width, depth, and mean velocity of each subsection. Multiply width, depth, and velocity to obtain discharge for each subsection. Sum increments to determine total discharge of stream

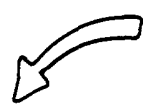

Construct stage-discharge rating from measured discharges at various stages

Collect continuous record of stage at gaging station. Combine rating with stage record to yield discharge record

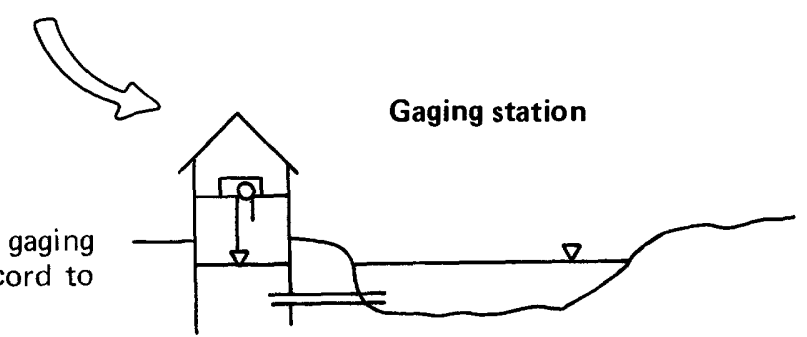

Figure 6.--Procedure for collection of streamflow data. 


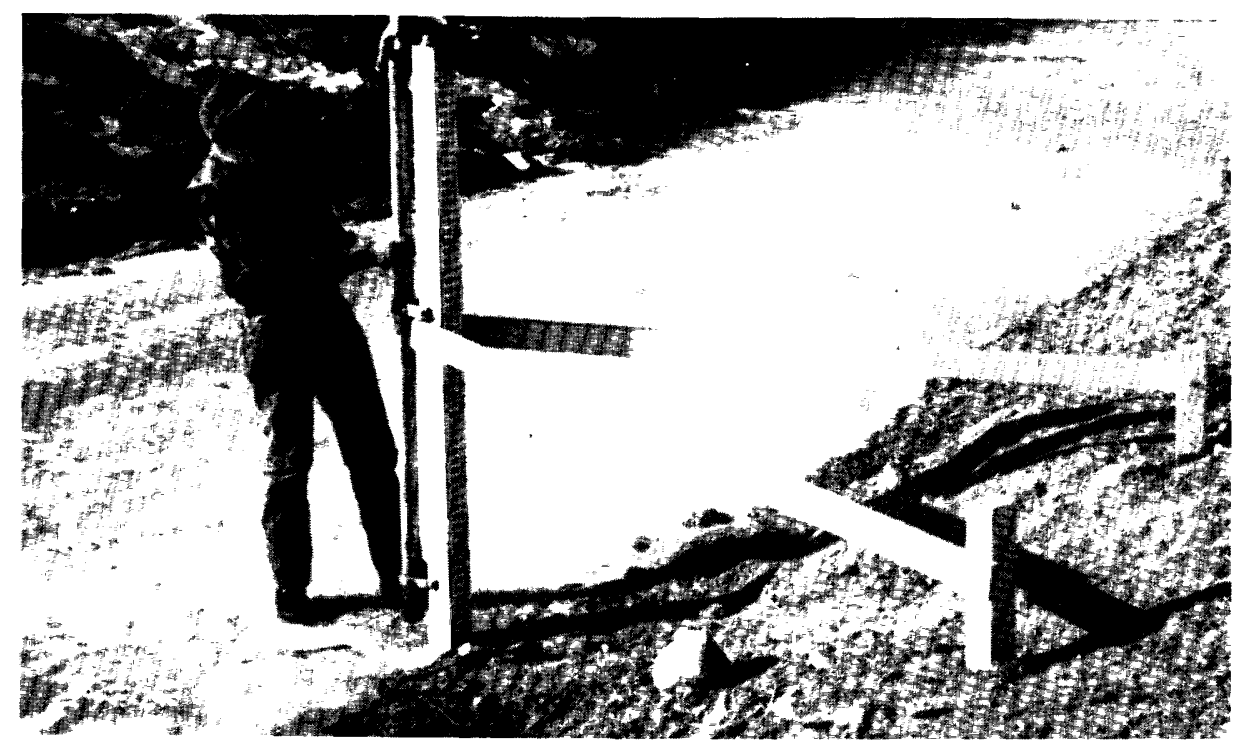

Figure 7.--Peak stages of floods are recorded by a crest-stage gage. 


\section{Availability of the Data}

Streamflow data collected by the Geological Survey are published in annual reports and also are available from computerized files. Further information concerning streamflow records for Wyoming may be obtained by contacting offices of the Water Resources Division in Cheyenne, Casper, or Riverton.

\section{STREAMFLOW CHARACTERISTICS AT GAGING STATIONS}

When streamflow data are needed in planning and engineering, averages or statistical summaries of gaged data are often used. For example, if a planner or builder of an irrigation project were interested in runoff of a stream, monthly and yearly runoff values probably would be examined in comparison with the water demand for the irrigation period. If a bridge or culvert were to be installed on a stream, records and computations of high flows would be used as input to the design.

Streamflow-gaging stations that were used in this study are listed in table 7a; locations of the stations are shown on plate 1c. Peak-fJ.ow characteristics and mean annual flows at these stations are 1 isted in table 7b. Drainage-basin characteristics are listed in table 7c. (Tables 7a through 7c are at the end of this report.) Only stations with records representative of natural streamflows, which were virtually unaffected by mancaused effects, were selected; 361 stations were used in the final analysj.s. The tables summarize data in the computer files of the U.S. Geological Survey as of December 1986, which generally included all data available through the 1985 water year.

As indicated in tables $7 \mathrm{a}$ to $7 \mathrm{c}$ and on plate 1c, a large data base exists for perennial streams draining mountainous areas of the State; however, a shortage of continuous records exists for small streams in the plains and desert areas of the state. To alleviate this shortage of runoff data, the records of 21 seasonal gages, which were operated during the princifal rainfall months of May through September of 1963-73, were included in the analysis. These gages were operated on ephemeral streams to calibrate rainfall-runoff relations for small drainage basins as part of a cooperative program between the U.S. Geological Survey, Wyoming Highway Department, and Federal Highway Administration (Craig and Rankl, 1978). The peak-f]ow characteristics listed in table $7 \mathrm{~b}$ for these stations are from the Craig-Rankl report.

The runoff data collected by the 21 seasonal gages were published by Rankl and Barker (1977). A review of similar streams having year-round records indicated that, on a statewide average, 60 percent of the mean annual flow of ephemeral streams in the plains and desert areas occurs during l'ay through September. Therefore, it was assumed that 60 percent of the actual mean annual flow was measured during May through September. An estimated mean annual flow at each of the 21 seasonal gages was computed on this basis. It is realized that differences do occur from year-to-year and from site-to-site, and the values are considered to be approximate; however, they do constitute a valuable data base that was very useful in the subsequent regional analysis. 


\section{Flood Magnitude}

The floodflow characteristics presented for the stations in table $7 \mathrm{k}$ are annual peak discharges for selected recurrence intervals, as determined by the Pearson Type III probability distribution with logarithmic transformation of annual flood data (log-Pearson Type II distribution). The procedure recommended in Bulletin 17B of the U.S. Water Resources Council (1981) was used. Peak-flow characteristics in this report are abbreviated as $P_{t}$, with $P$ being the annual peak flow, in cubic feet per second, and $t$ being the recurrence interval, in years. For example, $P, 100$ refers to an annual peak discharge that would be expected to be exceeded at intervals averaging 100 years.

The technical methods recommended in Bulletin 17B have improved the peakflow characteristics over those derived by previous methods, especially in the plains and desert areas of Wyoming. When dealing with short periods of record, use of a generalized skew coefficient and addition of historical data from outside the gaged period of record are helpful in refining the frequency curve. Significant adjustments to the records of 10 gaging stations (table $7 \mathrm{~b})$ were made on the basis of field investigations of historical floods by Maurice E. Cooley (written commun., 1986).

\section{Annual Runoff}

The runoff at gaging stations listed in table $7 \mathrm{~b}$ is expressed as mean annual flow, in cubic feet per second, which is abbreviated in this report as $Q_{2}$. Runoff was computed only for those stations having 5 or more complete yêars of record.

\section{ESTIMATION OF STREAMFLOW CHARACTERISTICS AT UNGAGED SITES}

Time and cost constraints prevent the installation and operation of gages at every site where streamflow information may be needed. If no gaging station has been operated at or near a site where stream-related development is planned, estimates of streamflow are useful. Several methods are available for estimating streamflow; however, one technique has become widely used during recent years, and that is to develop equations that relate streanflow characteristics to features of the drainage basin. The equations are developed through a statistical process known as regression analysis. Data used in the regression analysis are for gaged streams; the resultant equations depict streamflow and may be applied to ungaged streams where estimates are needed. Basin features for an ungaged site are used in the equations to obtain estimated streamflow characteristics at that site.

Methods are presented in this report for estimating peak-flow characteristics and mean monthly and annual flows of Wyoming streams. Two independent methods of estimating peak-flow characteristics and mean annual flow are presented: (1) The basin-characteristics method--developed by relating physical and climatic characteristics of the drainage basin to flow characteristics of the stream, and (2) the channel-geometry method--developed by relating channel features to flow characteristics. The methods were analyzed and developed separately due to inherent differences between lasin characteristics and channel features. Basin characteristics (including 
precipitation) are considered to be cause-effect variables because they produce or affect the outcome of flows. In contrast, channel features are considered to be resultant-effect variables; that is, the dimensions of a channel are the result of past flows. The advantage of presenting both methods in this report is that the users may select the one most suitable for their purposes. If both methods are used, a comparison of the results may be made.

\section{Regression Models}

The estimating equations were developed using a digital computer and multiple regression programs of the Statistical Analysis System (sAS Institute, Inc., 1982). The equations express flow characteristics (dependent variables) in relation to either basin characteristics or channel-geometry features (independent variables). The data were transformed to logaritrms before relations were developed; experience has proved that linear relations can be approached by such transformation of hydrologic variables. After converting the results to antilogarithms, the form of the resultant equation is :

$$
P=a A^{b} B^{c} C^{d} \ldots \ldots
$$

where $\quad P=$ the flow characteristic (a dependent variable);

$A, B$, and $C=$ basin characteristics or channel features

(independent variables);

$a=$ the regression constant; and

$b, c$, and $d=$ regression coefficients.

Equations of the above form plot as straight lines on graph paper having logarithmic scales.

In the analysis for the plains and desert areas of Wyoming, a curvilinear relation (after logarithmic transformation) was determined to be mcre applicable than a linear relation as a model for estimating peak-flow characteristics when using drainage area as one of the independent variables. The resultant equation uses the following double-exponential form:

$$
P=a A^{b A^{c}} C^{d} \ldots \ldots \text {, }
$$

where $\quad P=$ the flow characteristic;

$A=$ drainage area and $C$ is another basin characteristic;

$b$ and $d=$ regression coefficients; and

$c=a$ coefficient that designates the amount of curvature

(or nonlinear component) in the relation.

Equations of the above form plot as a curved line on logarithmic-scaled graph paper.

The curvilinear relations are applicable for describing peak-f]ow characteristics in the plains and deserts due to the nature of precipitation that occurs in these areas. Precipitation from convective storms often is intense and produces much greater unit runoff than general rainstorms or snowmelt produce. However, convective storms rarely cover areas of more tran 10 square miles. In small basins, the largest flows generally are the resilt of runoff from convective storms. In large basins (several hundred square 
miles or more), the largest flows generally are the result of widespread general rainstorms or snowmelt. As basin size increases, the unit rate of runoff decreases nonlinearly because the most dominant type of storm-runoff event changes from convective storms to general rainstorms and snowmelt. A curvilinear regression model accounts for this transition. A visual comparison of data plots as well as a comparison of the regression statistics verified that the curvilinear model provided a much better fit than the linear model.

\section{Hydrologic Regions}

Wyoming has a diverse terrain, and streamflow varies greatly fron the mountains to the plains and deserts due to differences in climate, topography, and geology. These conditions cannot be wholly defined or explained by numeric variables. Therefore, it is necessary to develop more than one set of equations for estimating streamflow throughout the State. Different set:s of equations are necessary--one set for each region of hydrologic similarity. In an earlier study, Lowham (1976) analyzed streamflows in the state using four regions. In the current study, advanced analytical methods and more complete streamflow data indicate that three regions are adequate. These refions (shown on plate 1a) were defined initially through the use of color inf ared imagery that highlighted areal differences in surface geology, vegetation, and soil moisture. Boundaries of the regions were then refined on the basis of known streamflow and climatic characteristics. The three hydrologic regions are the same for both the basin-characteristics and channel-geometry methods, and for both peak-flow characteristics and mean annual flows.

The major mountainous areas of the State are designated in this report as being in the Mountainous Regions. Streamflows in these areas occur mainl.y as a result of snowmelt runoff. Peak flows in the Mountainous Regions are small in relation to flows in the other regions, but annual runoff is larger.

In the plains and desert areas of the State, streamflows occur primarily as a result of rainstorm runoff. In the northern and eastern plains and deserts, intense activity from convective storms causes peak flows to be relatively large but highly variable in occurrence from year-to-year. These areas are mainly high plains and are designated in this report as being in the Plains Region.

Streams in the south-central and southwestern plains and desert areas have peak flows that are relatively smaller than those of the Plains Rerion. This is a result of precipitation occurring more in the form of wides read general rainstorms and snow and less as activity from convective storms. These areas are largely desert and are designated as being in the High Disert Region.

\section{Geographic Factors}

During the analyses of data for streams in the Plains and High Drsert Regions it became apparent that peak-flow characteristics at groups of gaging stations in particular areas had larger or smaller values than would be estimated by the regression equations. The differences between the gaget and estimated values were plotted on a map of the State, and a comparison of the plot with the color infrared imagery of the state showed that certain areas 
were yielding larger or smaller peak flows due to geographic and orographic differences that were not quantified by the independent variables. For example, several areas of the State have extensive sand dunes where infiltration is high, and for which flood runoff should be relatively small. Using residual values of the regression for groups of stations, and color differences on the imagery that were due to differences in surface geology and vegetation, lines of equal geographic factors $\left(G_{f}\right)$ were constructed that account for part of the differences in peak-flow characteristics. Te residual values for regressions from both the basin-characteristics and channel-geometry methods were used to help determine the geographic factor. The lines of equal geographic factors for Wyoming are shown on plate 1d; these factors are included in the equations for estimating peak-flow characteristics in the Plains and High Desert Regions. Similar development and application of geographic factors in equations for estimation of peak-flow characteristics in Montana have been made by Omang and others (1986, p. 14-17).

\section{Basin-Characteristics Method}

Regression using basin characteristics is based on the assumption that certain physical and climatic variables produce or affect streamflow from a basin. The equations express flow characteristics (dependent variables) as being correlated to basin characteristics (independent variables). The methrd has the advantage of being an "office" technique. The basin characteristics are determined from maps of the drainage basin, and a field visit is not required.

Ten physical variables measured for each of the gaged basins include contributing drainage area; channel slope, length, and aspect; area of lakes and ponds; soils-infiltration rate; mean basin latitude and elevation; percent forest cover; and basin slope. Three climatic variables measured for each basin include average annual precipitation, intensity of rainstorm precipitation, and average length of growing season.

For the Mountainous Regions, drainage area, mean basin elevation, and mean annual precipitation were statistically significant as independent variables in estimating peak-flow characteristics and mean annual flow. Mean basin elevation and mean annual precipitation were determined to be highly correlated. Therefore, one set of equations using drainage area and mean basin elevation as independent variables is presented; a second set using drainage area and mean annual precipitation as independent variables is also presented. Based on the regression statistics, the equations using elevation should yield a slightly more accurate estimate of discharge, on the average. However, the equations using precipitation are much simpler to apply and, for most applications, are considered the most feasible to use.

For the Plains Region, drainage area and basin slope were determined to be significant as independent variables for estimating peak flows. For the High Desert Region, drainage area and mean annual precipitation were determined to be significant for estimating peak-flow characteristics. T're geographic factor from plate 1d also is included in the the equations for bcth of these regions. Mean annual flow in the Plains and High Desert Regions also was determined to be significantly related to drainage area and average annual precipitation. 
A description of the variables that were determined to be significant follows:

Contributing drainage area (A), in square miles, as measured by a planimeter on the best available topographic maps.

Mean basin elevation (ELEV), in feet above sea level, measured on $1: 250,000$-scale topographic maps. The measurement can be made by either: (1) laying a grid over the map, determining the elevation for at least 25 evenlyspaced intersections within the basin, and averaging those elevations, $\mathrm{cr}$ (2) by determining the subareas within each contour interval, multiplying the subareas by the intermediate elevation, totaling the products, and then dividing by the total basin area. When possible, the contour intervals selected to be measured should provide not less than four subareas.

Average annual precipitation (PR), in inches. For gaged basins in Wyoming, the value of average annual precipitation was determined from plate $1 \mathrm{~b}$; for basins outside Wyoming, it was obtained from similar precipitation maps for the respective states. The measurement is made by sketching the drainage boundary on a transparent overlay on plate $1 \mathrm{~b}$, and computing the basin average by weighting subareas for each respective precipitation interval.

Basin slope $\left(S_{B}\right)$, in feet per mile, determined by measuring the lengths, in miles, of contour lines within the drainage boundary, multiplying by the contour interval in feet, and dividing by the drainage area, in square miles. For basins of 50 square miles or less, maps of 1:24,000-scale are recommended to determine the bas in slope. Reasonable accuracy generally can be obtained by measuring only the 100-foot contour lines. For basins of 50 to 300 square miles, 1:250,000-scale topographic maps are recommended. For basins Jarger than 300 square miles, basin slope generally approaches an average value of about 500 feet per mile. Due to the difficulty in measuring this characteristic for large basins, using a value of 500 feet per mile is recommended when the equations are applied to basins larger than 300 square miles.

The basin characteristics of significance in the regression analysis are listed for the gaged sites in table $7 \mathrm{c}$ (at end of this report).

Use

The basin-characteristics method requires locating the site in question on the most accurate map available, preferably a 1:24,000-scale Geolngical Survey topographic map, or equivalent. The basin boundary is then delineated, and the contributing drainage area is determined. Depending on the set of equations used, the geographic factor and other necessary variables are determined. The map of the basin should be examined to determine wlether significant manmade works could affect natural streamflows. Although a field visit is not required to use the method, it is advisable to determine any unusual conditions. For example, detention dams and other works may have been constructed after completion of the most recent mapping. Example applications are given in a subsequent section (page 36 ). 


\section{Limitations}

The basin-characteristics method is applicable only to sites having virtually natural streamflows. The equations should not be applied to estimate streamflows that are significantly affected by major dans, diversions, or other works of man. The equations could be applied in such cases to estimate what the natural flows were before the manmade works were constructed. In situations where flood characteristics of urban watersheds are needed, the equations for the basin-characteristics method can be used in conjunction with adjustments described by Sauer and others (1983).

\section{Channel-Geometry Method}

The size of a natural channel is an indication of flow magnitude. Large flows create large channels; smaller flows create smaller channels. A channel forms primarily during floodflows when a stream has tremendous energy and is transporting large quantities of sediment. Erosion and deposition occur as the stream sculptures its channel to a size large enough to accommodate its flows.

Streamflows of about bankfull magnitude usually dominate channel formation (Wolman and Miller, 1960). Although bankfull discharge, which has a recurrence interval of about 2 years (Lowham, 1982, p. 20-24), is most dominant in channel formation, other discharge characteristics, such as the 50- and 100-year peak flows and mean annual flow, are related to bankfull discharge. These additional characteristics are related to channel size, and estimation equations can be developed through regression analysis.

Several channel-geometry features, including width, depth, and the widthto-depth ratio of the stream channel, were measured and tested as independent variables for determining streamflow characteristics. Channel-geometry features were measured at nearly all of the gaged sites used in this study where the channels were suitable for measurement.

In a previous study (Lowham, 1976) for Wyoming streams, channel width was the only significant variable in estimating discharge. Depth of the channel is difficult to measure accurately and consistently because the streambeds of many channels are scoured during floodflow but fill in as the flow recedes. Rather than using depth or the width-to-depth ratio as independent variables, it was considered that a more accurate measurement of channel shape would be indicated by some measurement of the streambed and bank material. This approach was based on the results of several previous studies. For example, the percentage of silt and clay in the streambed and banks was found by Schumm (1960) to have a significant effect on channel shape. In addition to channelgeometry features, channel sediment properties were used by Osterkamp (1977) to develop equations for estimating mean discharge of Kansas streams, and by Osterkamp and Hedman (1982) to develop equations for perennial streams in the Missouri River basin.

To determine whether channel sediment properties could be used to improve the channel-geometry relations for the plains and desert areas of Wyoming, samples of the streambeds and banks at 23 gaged sites were collected for testing. A regression study was made for just these sites to determine whether the equations, using width as an independent variable, could be improved by the addition of a variable describing channel material. Several 
measurements of streambed and bank composition (including particle size, percent silt and clay, and soil cohesiveness) were collected and tested; however, none proved to be significant in the analysis. The conclusion was, that although the composition of channel material is presumably interrelated to channel size and discharge, the variable nature of surficial deposits in the plains and deserts of Wyoming masked the attempt to quantitatively describe magnitude of streamflow with any channel feature other than widtr.

The width (WIDTH) of the channel was determined to be a significant independent variable for estimating streamflow in all regions of the State. Widths of all channels that were measured are listed in table $7 \mathrm{c}$. The geographic factor $\left(G_{f}\right)$ from plate $1 d$ also is included in the equations for estimating peak-flow characteristics in the Plains and High Desert Regions.

Use

Although measuring channel features is fairly simple, some experience is required. A field visit is necessary to measure the channel width. A ridth measurement is made of the stream channel at the narrowest section of a straight reach. The section should have a stable appearance; that is, it should be one that has been fairly permanent for several years and not severely disturbed by large floods. It is a good practice to measure channel widths downstream from several meanders and then average the results. The distance from the top of one bank to the top of the adjacent bank of the stream channel is measured. (The top of the bank is defined as that spot where the flood plain and channel meet, and it is distinguished by a break in slope.) If a person were to climb out of a stream channel, they generally would dig in their toes to climb the bank, but could begin walking on flat ground when they reached the top (break in slope) of the bank.

Sketches in figure 8 show where the channel width should be measured. As shown in the sketches, the measurement is made of the narrowest, most stable section of a channel, generally just downstream from a curve or reach of rapids where large amounts of energy are dissipated. Streamflow dissipates energy in curves and rapids; therefore, the channel just downstream from these features reflects the relatively low energy and minimum erosion potenticl of the streamflow. When a point bar is present, the narrowest section generally will be located at the point where the downstream end of the bar meets the bank. Little or no erosion generally will be evident at this section.

Photographs in figures 9-12 show examples of widths measured in several channels. A large collection of color slides that clearly show where measurements were made on a variety of channel types is on file in the Geological Survey office in Cheyenne. Persons who plan to use the mathod would benefit from viewing these slides, as well as from field instruction by someone who is experienced with the method. 


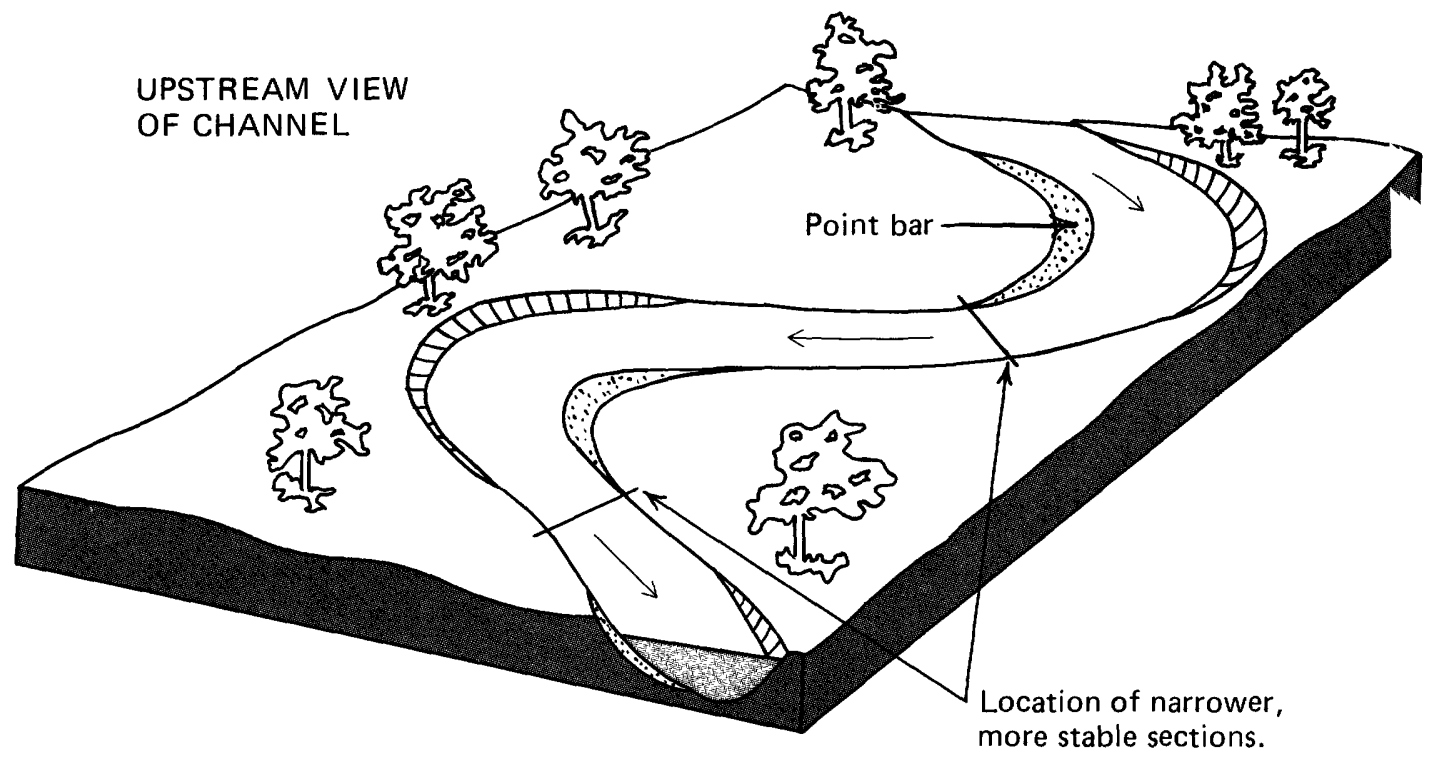

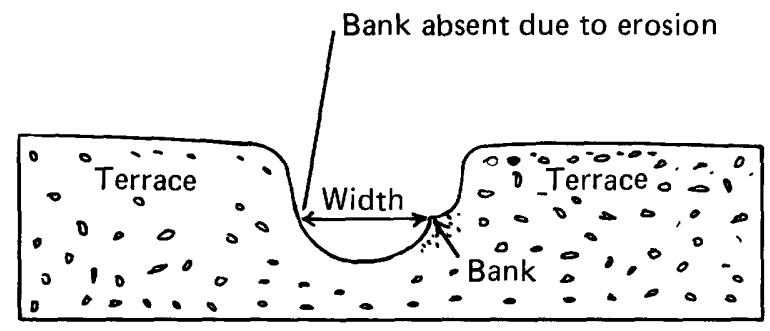

Channel whose streambed has eroded in recent past due to a change in climate or land use. Banks will be present if the channel has stabilized to existing conditions.

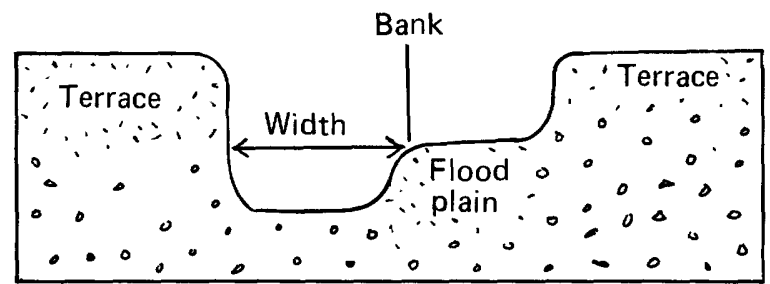

Channel whose streambed has eroded in past. The channel has stabilized and a new flood plain is developing.

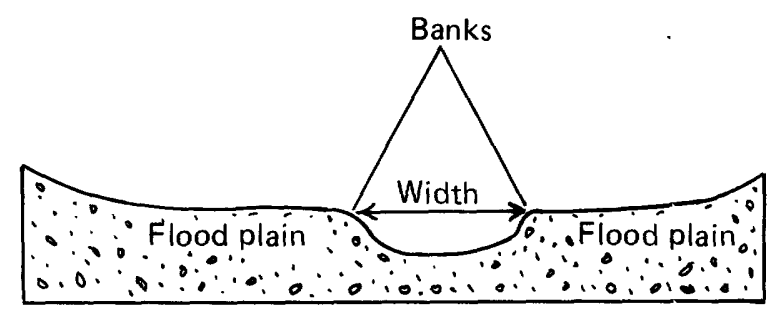

Channel with well-developed flood plain.

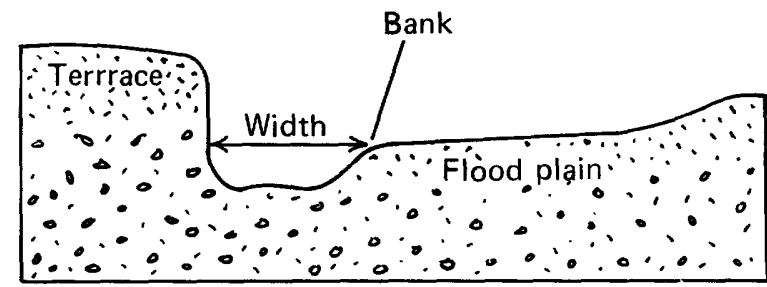

Meandering channel whose lateral movement causes it to be eroding the valley terrace.

Figure 8.--Cross sections of various types of stream channels where width should be measured. 


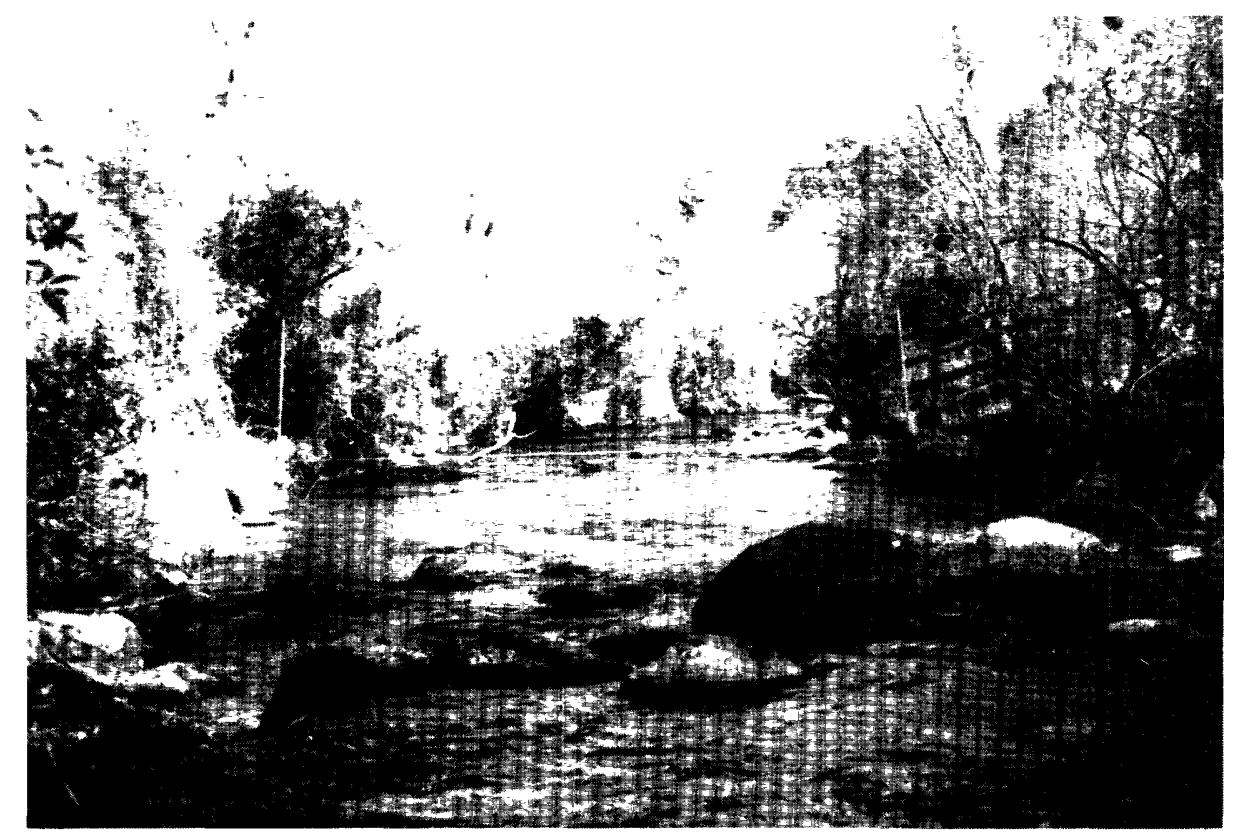

Figure 9.--Tape and stakes show where channel width was measured on North Fork Crazy Woman Creek near Buffalo. View is downstream, width $=24$ feet.

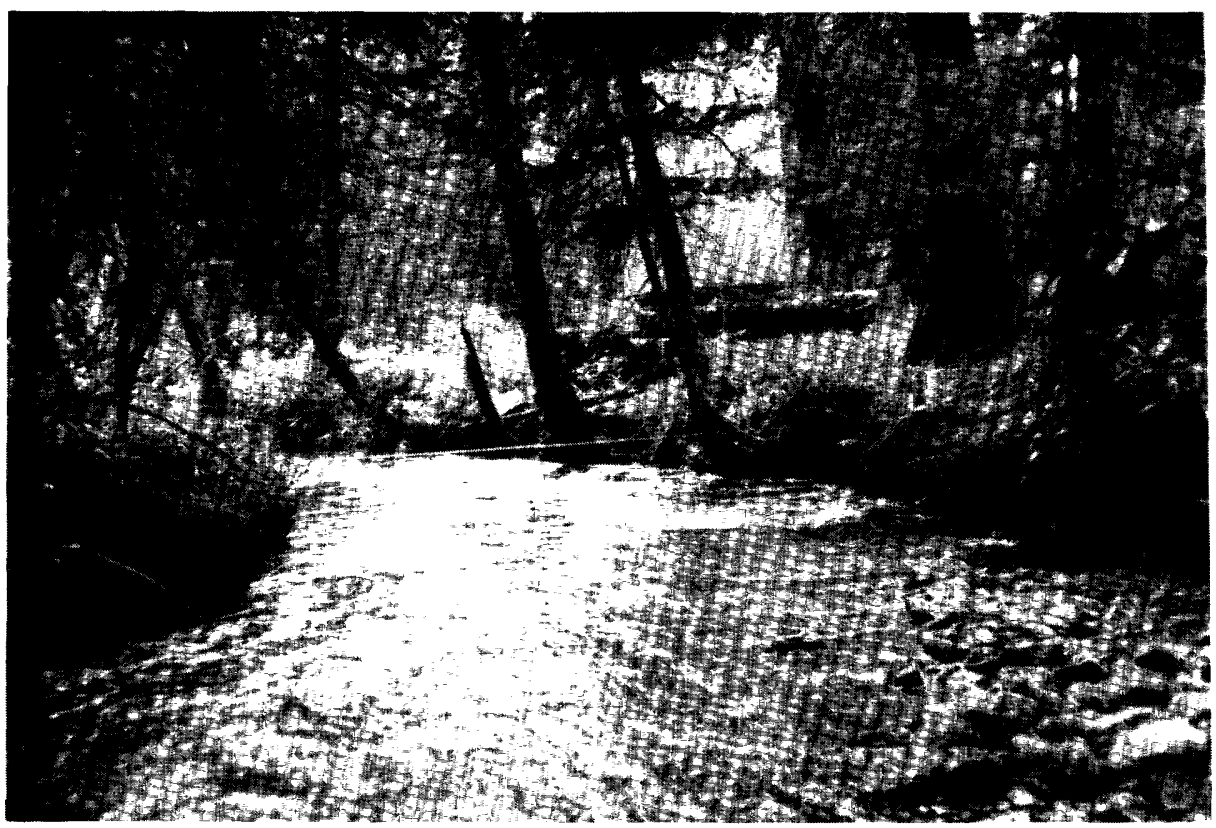

Figure 10.--Tape and stakes show where channel width was measured on Cache Creek near Jackson. View is downstream, width $=12$ feet. 


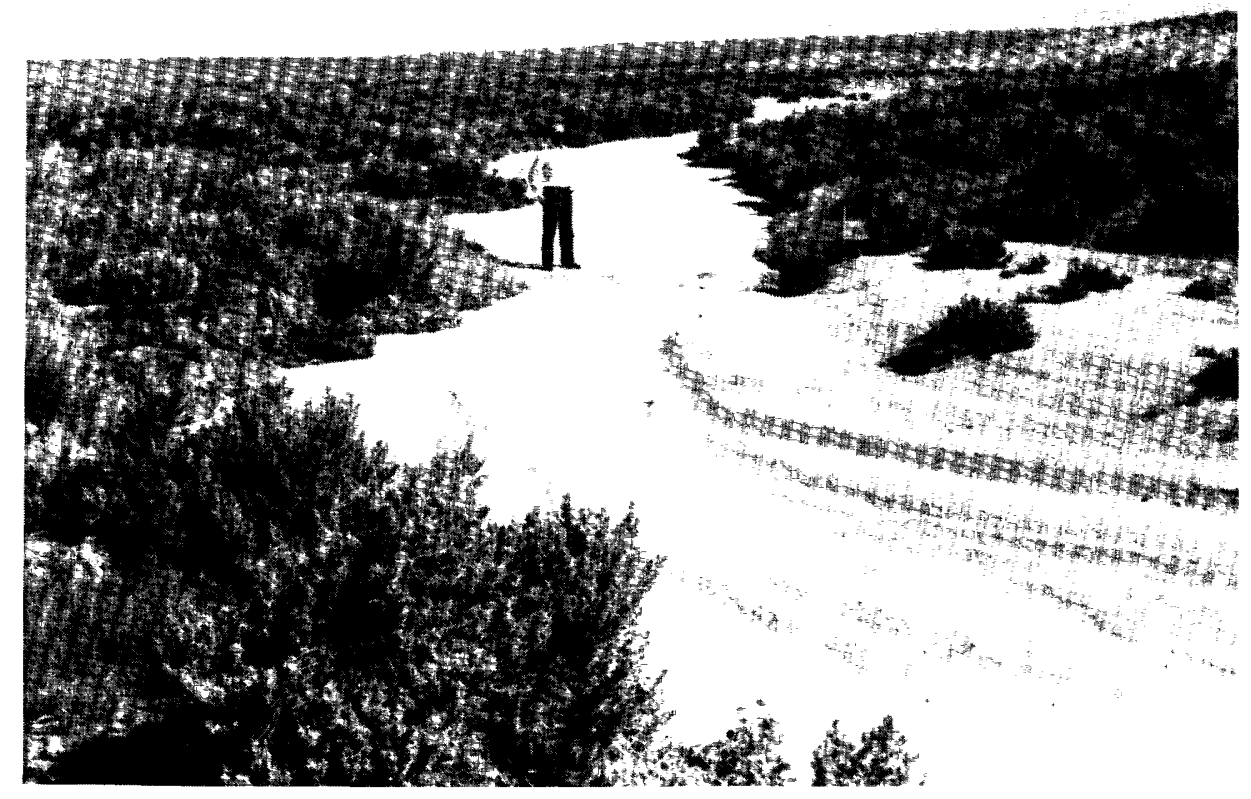

Figure 11.--Tape and stakes show where channel width was measured on Sand Springs Draw near Pinedale. View is downstream, width $=16$ feet.

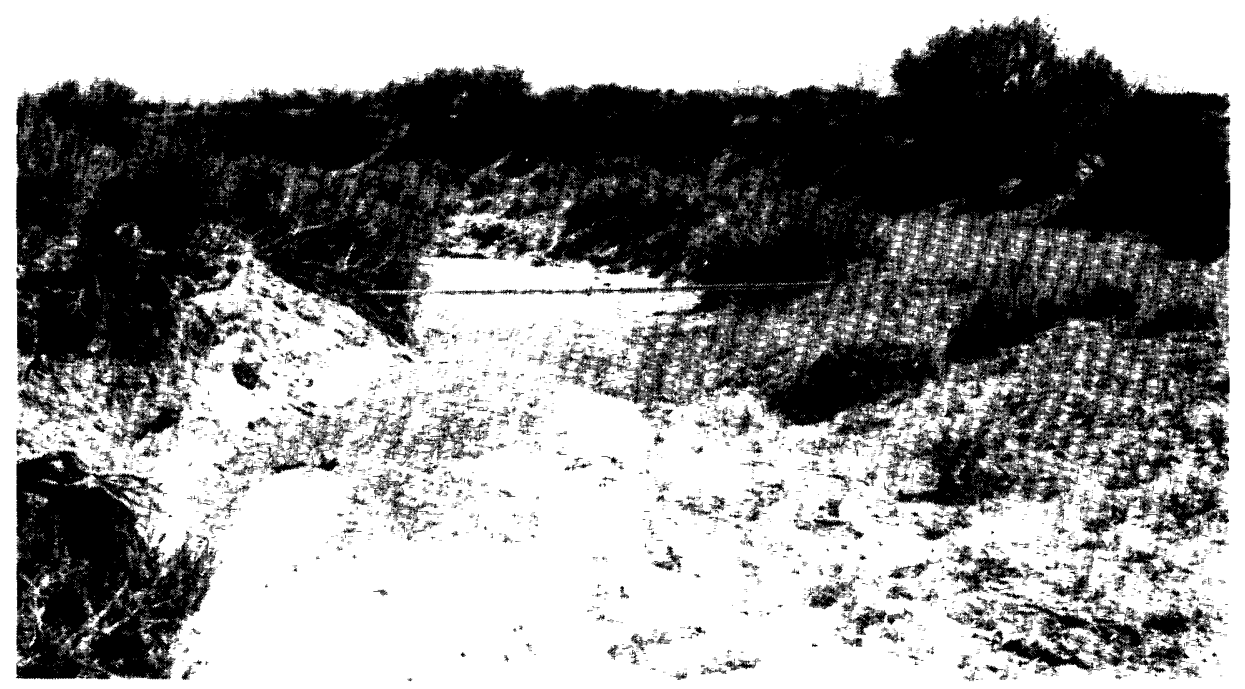

Figure 12.--Rod and stakes show where channel width was measured on tributary to the New Fork River near Big Piney. View is downstream, width $=12$ feet. 


\section{Limitations}

The channel-geometry method should not be used on certain stream reaches. These include reaches having:

1. Flows that are not frequent enough to form and maintain a channel. Flow is conveyed in a grassy swale that does not have well-defined banks. In general, stream channels with widths less than 2 feet in the Mountainous Regions and less than 4 feet in the Plains and High Desert Regions are not well defined and should not be used.

2. Braided channels. Streambanks in such channels are unstable, and flow often is in multiple channels. A stable channel reach occasionally can be found either upstream or downstream from the braided reach.

3. Potholes. On some intermittent streams the ground-water level is near the streambed elevation but inflow to the stream channel is insufficient to sustain perennial flow. During much of the year evaporation equals or exceeds the seepage inflow. Although the channel contains ponded water, there is no flow in the stream. The dissolved-solids concentration of the ponded water gradually increases to a level that vegetation cannot survive. The bed material of the channel is loosened by the buoyant forces of grcundwater seepage, and subsequent flows erode the bed and form potholes.

4. Significant alterations such as diking and channelization, or receches that are near enough to such alterations to have been significantly influenced or altered.

5. Large reservoirs or diversions upstream. On streams where large dams have been constructed, gaged data generally are available.

The criterion necessary to apply the channel-geometry method is that the channel to be measured should have been formed primarily by the forces of streamflow under its present regime. The method is not applicable when other influences, such as overgrowth of vegetation, wind deposits, movement of livestock and wildlife, and developments of man, are more dominant than the streamflow in forming the size and shape of the channel.

\section{Regression Relations}

Tables 1 to 4 present the estimation equations, the number of stations used in each regression analysis, the average standard error of estimate, and the correlation coefficient. The equations were developed using inch-pound units and must be entered with inch-pound units unless applicable conversion factors are applied. The equations should be used for estimating streanflow characteristics only within the ranges of data used for their development. A summary showing the ranges of data available for the regression analyses is listed in table 5. Extending the equations to estimate flow characteristics outside the defined ranges is discouraged. 
Table 1.--Summary of regression relations for estimating peak-flow characteristics and mean annual flow of streams

in the Mountainous Regions

$\left[P_{t}\right.$, annual peak flow, in cubic feet per second, with subscript $t$ designating the recurrence interval, in years; $Q_{2}$, mean annual flow, in cubic feet per second; $A$, contributing grainage area, in square miles; ELEV, mean basin elevation, in feet; PR, average annual precipitation, in inches, as determined from plate 1b; WIDTH, channel width, in feet]

\begin{tabular}{cccc}
\hline & Number & Average & \\
$\begin{array}{c}\text { Regression equation } \\
\text { (inch-pound units) }\end{array}$ & of & standard error, & Correlation \\
in percent & coefficient \\
\hline
\end{tabular}

Equations based on contributing drainage area (A) and mean basin elevation (ELEV)

\begin{tabular}{|c|c|c|c|c|c|c|}
\hline $\mathrm{P}_{2}$ & $=0.012$ & $A^{0.88}$ & $\left(\frac{\text { ELEV }}{1,000}\right)^{3.25}$ & 170 & 55 & 0.93 \\
\hline$P_{5}$ & $=0.13$ & $A^{0.84}$ & $\left(\frac{\text { ELEV }}{1,000}\right)^{2.41}$ & 170 & 46 & .95 \\
\hline$P_{10}$ & $=0.45$ & $A^{0.82}$ & $\left(\frac{\text { ELEV }}{1,000}\right)^{1.95}$ & 170 & 44 & .95 \\
\hline$P_{25}$ & $=1.75$ & $A^{0.80}$ & $\left(\frac{\text { ELEV }}{1,000}\right)^{1.46}$ & 170 & 44 & .94 \\
\hline$P_{50}$ & $=4.29$ & $A^{0.79}$ & $\left(\frac{\text { ELEV }}{1,000}\right)^{1.13}$ & 170 & 47 & .94 \\
\hline$P_{100}$ & $=9.63$ & $\mathrm{~A}^{0.77}$ & $\left(\frac{E L E V}{1,000}\right)^{0.85}$ & 170 & 50 & .93 \\
\hline$P_{200}$ & $=25.9$ & $A^{0.75}$ & $\left(\frac{\text { ELEV }}{1,000}\right)^{0.47}$ & 170 & 54 & .91 \\
\hline$P_{500}$ & $=63.4$ & $\mathrm{~A}^{0.74}$ & $\left(\frac{E L E V}{1,000}\right)^{0.14}$ & 170 & 61 & .89 \\
\hline$Q_{a}$ & $=0.0015$ & $5 \mathrm{~A}^{1.01}$ & $\left(\frac{\text { ELEV }}{1,000}\right)^{2.88}$ & 140 & 57 & .91 \\
\hline
\end{tabular}


Table 1.--Summary of regression relations for estimating peak-flow characteristics and mean annual flow of streams in the Mountainous Regions--Continued

\begin{tabular}{|c|c|c|c|c|c|}
\hline \multicolumn{3}{|c|}{$\begin{array}{l}\text { Regression equation } \\
\text { (inch-pound units) }\end{array}$} & $\begin{array}{l}\text { Number } \\
\text { of } \\
\text { stations }\end{array}$ & $\begin{array}{c}\text { Average } \\
\text { standard error, } \\
\text { in percent }\end{array}$ & $\begin{array}{l}\text { Correlation } \\
\text { coefficient }\end{array}$ \\
\hline \multicolumn{6}{|c|}{$\begin{array}{c}\text { Equations based on contributing drainage area (A) } \\
\text { and average annual precipitation (PR) }\end{array}$} \\
\hline $\mathrm{P}_{2}$ & $=0.51$ & $A^{0.81} P^{1.13}$ & 170 & 71 & .89 \\
\hline $\mathrm{P}_{5}$ & $=2.36$ & $\mathrm{~A}^{0.79} \mathrm{PR}^{0.78}$ & 170 & 56 & .92 \\
\hline $\mathrm{P}_{10}$ & $=5.35$ & $A^{0.78} P R^{0.59}$ & 170 & 52 & .93 \\
\hline $\mathrm{P}_{25}$ & $=13.5$ & $\mathrm{~A}^{0.77} \mathrm{PR}^{0.38}$ & 170 & 50 & .93 \\
\hline$P_{50}$ & $=23.8$ & $A^{0.77} P R^{0.25}$ & 170 & 50 & .93 \\
\hline$P_{100}$ & $=40.7$ & $A^{0.76} \mathrm{PR}^{0.13}$ & 170 & 52 & .92 \\
\hline$P_{200}$ & $=73.1$ & $A^{0.75} P^{-0.001}$ & 170 & 55 & .91 \\
\hline$P_{500}$ & $=136$ & $A^{0.74} \mathrm{PR}^{-0.15}$ & 170 & 61 & .89 \\
\hline $\mathrm{Q}_{\mathrm{a}}$ & $=0.013$ & $A^{0.93} \mathrm{PR}^{1.43}$ & 140 & 57 & .92 \\
\hline
\end{tabular}


Table 1.--Summary of regression relations for estimating peak-flow characteristics and mean annual flow of streams

in the Mountainous Regions--Continued

\begin{tabular}{|c|c|c|c|c|c|}
\hline & $\begin{array}{l}\text { gression } \\
\text { inch-pou }\end{array}$ & $\begin{array}{l}\text { equation } \\
\text { and units) }\end{array}$ & $\begin{array}{c}\text { Number } \\
\text { of } \\
\text { stations } \\
\end{array}$ & $\begin{array}{c}\text { Average } \\
\text { standard error, } \\
\text { in percent }\end{array}$ & $\begin{array}{l}\text { Correlation } \\
\text { coefficient }\end{array}$ \\
\hline \multicolumn{6}{|c|}{ Equations based on channel width (WIDTH) } \\
\hline $\mathrm{P}_{2}$ & $=1.94$ & WIDTH $^{1.58}$ & 98 & 39 & 0.96 \\
\hline $\mathrm{P}_{5}$ & $=4.33$ & WIDTH $^{1.47}$ & 98 & 33 & .96 \\
\hline$P_{10}$ & $=6.60$ & WIDTH $^{1.41}$ & 98 & 36 & .95 \\
\hline$P_{25}$ & $=10.4$ & WIDTH ${ }^{1.34}$ & 98 & 43 & .93 \\
\hline$P_{50}$ & $=13.9$ & WIDTH ${ }^{1.30}$ & 98 & 49 & .91 \\
\hline$P_{100}$ & $=18.1$ & WIDTH $^{1.27}$ & 98 & 56 & .88 \\
\hline$P_{200}$ & $=28.0$ & WIDTH $^{1.23}$ & 98 & 63 & .85 \\
\hline$P_{500}$ & $=31.0$ & WIDTH $^{1.19}$ & 98 & 73 & .81 \\
\hline$Q_{a}$ & $=0.087$ & WIDTH ${ }^{1.79}$ & 77 & 46 & .91 \\
\hline
\end{tabular}


Table 2.--Summary of regression relations for estimating peak-flow characteristics of streams in the Plains Region

$\left[P_{t}\right.$, annual peak flow, in cubic feet per second, with subscript $t$ designating the recurrence interval, in years; $A$, contributing drainage area, in square miles; $S_{B}$, basin slope, in feet per mile; $G_{f}$, geographic factor, as determined from plate $1 d$; WIDTH, channel width, in feet]

\begin{tabular}{|c|c|c|c|c|}
\hline & $\begin{array}{l}\text { gression equation } \\
\text { inch-pound units) }\end{array}$ & $\begin{array}{l}\text { Number } \\
\text { of } \\
\text { stations }\end{array}$ & $\begin{array}{l}\text { Average } \\
\text { standard error, } \\
\text { in percent }\end{array}$ & $\begin{array}{l}\text { Correlation } \\
\text { coefficient }\end{array}$ \\
\hline \multicolumn{5}{|c|}{$\begin{array}{l}\text { Equations based on contributing drainage area }(A) \text {, } \\
\text { basin slope }\left(S_{B}\right) \text {, and geographic factor }\left(G_{f}\right)\end{array}$} \\
\hline$P_{2}$ & $=41.3 A^{0.60 A^{-0.05}} G_{f}$ & 115 & 97 & 0.76 \\
\hline$P_{5}$ & $=63.7 \mathrm{~A}^{0.60 \mathrm{~A}^{-0.05}} \mathrm{~S}_{\mathrm{B}}^{0.09} \mathrm{G}_{\mathrm{f}}$ & 115 & 71 & .85 \\
\hline$P_{10}$ & $=76.9 A^{0.59 A^{-0.05}} S_{B}^{0.14} G_{f}$ & 115 & 63 & .87 \\
\hline $\mathrm{P}_{25}$ & $=94.2 A^{0.59 A^{-0.05}} S_{B}^{0.19} G_{f}$ & 115 & 62 & .88 \\
\hline$P_{50}$ & $=112 A^{0.58 A^{-0.05}} S_{B}^{0.23} G_{f}$ & 115 & 66 & .87 \\
\hline$P_{100}$ & $=130 A^{0.58 A^{-0.05}} S_{B}^{0.25} G_{f}$ & 115 & 73 & .85 \\
\hline$P_{200}$ & $=182 A^{0.57 A^{-0.05}} S_{B}^{0.26} G_{f}$ & 109 & 82 & .80 \\
\hline$P_{500}$ & $=245 A^{0.57 A^{-0.05}} S_{B}^{0.27} G_{f}$ & 109 & 98 & .76 \\
\hline
\end{tabular}


Table 2.--Summary of regression relations for estimating peak-flow characteristics of streams in the Plains Region--Continued

\begin{tabular}{|c|c|c|c|}
\hline $\begin{array}{r}\text { Regression equation } \\
\text { (inch-pound units) }\end{array}$ & $\begin{array}{c}\text { Number } \\
\text { of } \\
\text { stations }\end{array}$ & $\begin{array}{c}\text { Average } \\
\text { standard error, } \\
\text { in percent }\end{array}$ & $\begin{array}{l}\text { Correlation } \\
\text { coefficient }\end{array}$ \\
\hline \multicolumn{4}{|c|}{ Equations based on channel width (WIDTH) and geographic factor $\left(G_{f}\right)$} \\
\hline$=7.60 \mathrm{WIDTH}^{1.18} \mathrm{G}_{\mathrm{f}}$ & 41 & 59 & 0.87 \\
\hline$P_{5}=20.5 \mathrm{WIDTH}^{1.14} \mathrm{G}_{\mathrm{f}}$ & 41 & 45 & .91 \\
\hline$P_{10}=34.6 \mathrm{WIDTH}^{1.11} \mathrm{G}_{\mathrm{f}}$ & 41 & 44 & .91 \\
\hline$P_{25}=60.9 \mathrm{WIDTH}^{1.09} \mathrm{G}_{\mathrm{f}}$ & 41 & 48 & .90 \\
\hline$P_{50}=88.0 \mathrm{WIDTH}^{1.07} \mathrm{G}_{\mathrm{f}}$ & 41 & 53 & .87 \\
\hline $\mathrm{P}_{100}=123 \mathrm{WIDTH}^{1.06} \mathrm{G}_{\mathrm{f}}$ & 41 & 60 & .85 \\
\hline$P_{200}=166$ WIDTH $^{1.04} G_{f}$ & 41 & 68 & .82 \\
\hline$P_{500}=239$ WIDTH $^{1.03} \mathrm{G}_{\mathrm{f}}$ & 41 & 78 & .77 \\
\hline
\end{tabular}


Table 3.--Summary of regression relations for estimating peak-flow characteristics of streams in the High Desert Region

$\left[P_{t}\right.$, annual peak flow, in cubic feet per second, with subscript $t$ designating the recurrence interval, in years; $A$, contributing drainage area, in square miles; PR, average annual precipitation, in inches, as determined from plate $1 b ; G_{f}$, geographic factor, as determined from plate 1d; WIDTH, channel width, in feet]

\begin{tabular}{|c|c|c|c|c|}
\hline & $\begin{array}{l}\text { egression equation } \\
\text { (inch-pound units) }\end{array}$ & $\begin{array}{l}\text { Number } \\
\text { of } \\
\text { stations }\end{array}$ & $\begin{array}{c}\text { Average } \\
\text { standard error, } \\
\text { in percent }\end{array}$ & $\begin{array}{l}\text { Correlation } \\
\text { coefficient }\end{array}$ \\
\hline \multicolumn{5}{|c|}{$\begin{array}{c}\text { Equations based on contributing drainage area }(A) \text {, average } \\
\text { annual precipitation (PR), and geographic factor }\left(G_{f}\right)\end{array}$} \\
\hline $\mathrm{P}_{2}$ & 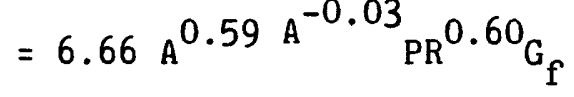 & 43 & 67 & 0.80 \\
\hline$P_{5}$ & $=10.6 A^{0.56 A^{-0.03}}{ }_{P R}^{0.81}$ & 43 & 57 & .82 \\
\hline$P_{10}$ & $=13.8 A^{0.55 A^{-0.03}}{ }_{P R}^{0.90} G_{f}$ & 43 & 54 & .82 \\
\hline $\mathrm{P}_{25}$ & $=19.4 A^{0.53 A^{-0.03}} P^{0.98} G_{f}$ & 43 & 53 & .81 \\
\hline$P_{50}$ & $=24.2 A^{0.52 A^{-0.03} P R^{1.02} G_{f}}$ & 43 & 54 & .80 \\
\hline $\mathrm{P}_{100}$ & $=30.1 A^{0.51 A^{-0.03}} \mathrm{PR}^{1.05} \mathrm{G}_{\mathrm{f}}$ & 43 & 55 & .78 \\
\hline$P_{200}$ & $=36.0 A^{0.51 A^{-0.03}} \mathrm{PR}^{1.07} \mathrm{G}_{\mathrm{f}}$ & 43 & 58 & .75 \\
\hline$P_{500}$ & $=47.1 A^{0.50 A^{-0.03}} \mathrm{PR}^{1.09} \mathrm{G}_{\mathrm{f}}$ & 43 & 62 & .71 \\
\hline
\end{tabular}


Table 3.--Summary of regression relations for estimating peak-flow characteristics of streams in the High Desert Region--Continued

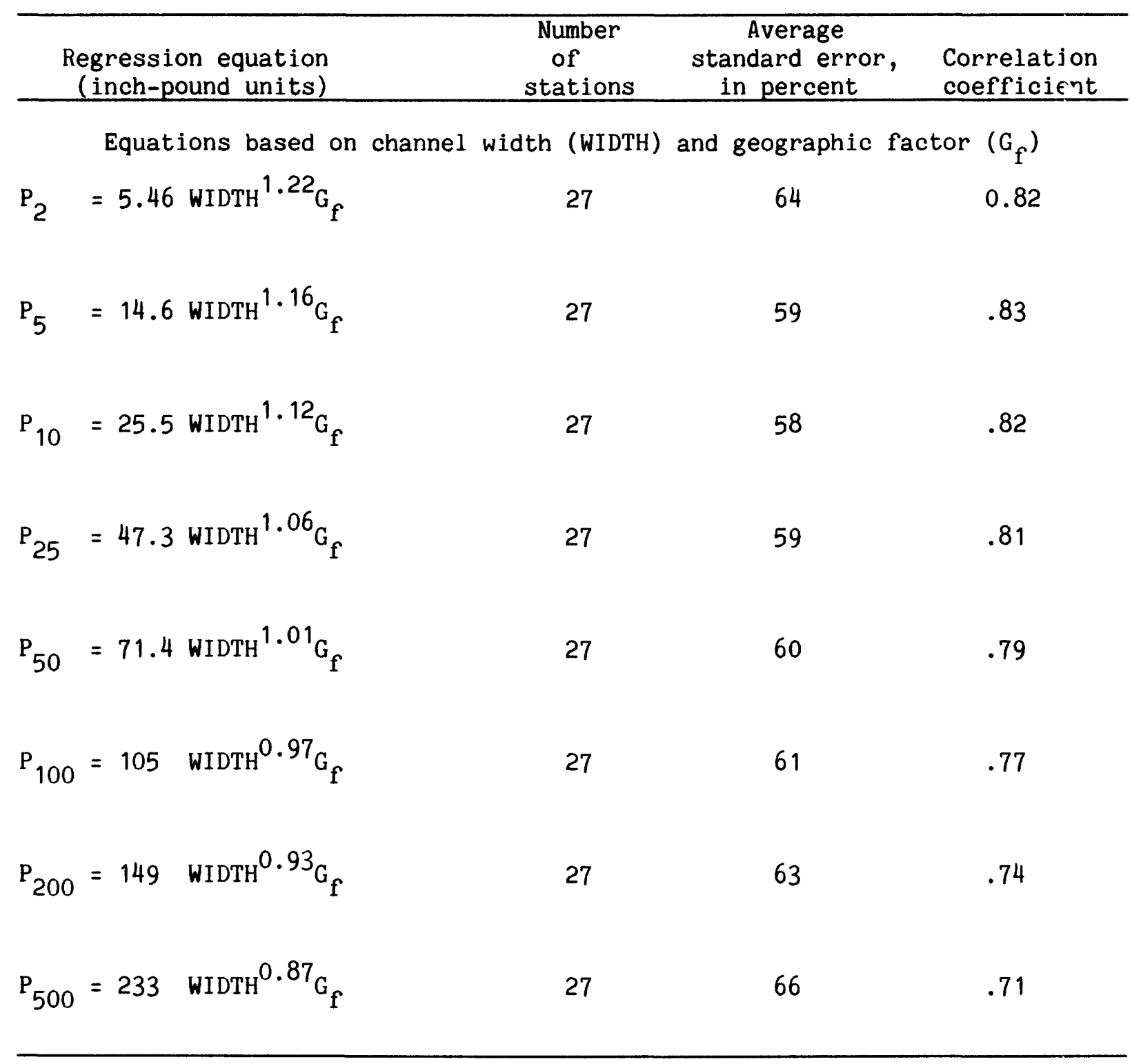


Table 4.--Summary of regression relations for estimating mean annual flow of streams in the Plains and High Desert Regions

$\left[Q_{a}\right.$, mean annual flow, in cubic feet per second;

$A$, contributing drainage area, in square miles; $\mathrm{PR}$, average annual precipitation, in inches, as determined

from plate 1b; WIDTH, channel width, in feet]

\begin{tabular}{|c|c|c|c|}
\hline $\begin{array}{l}\text { Regression equation } \\
\text { (inch-pound units) }\end{array}$ & $\begin{array}{c}\text { Number } \\
\text { of } \\
\text { stations }\end{array}$ & $\begin{array}{c}\text { Average } \\
\text { standard error, } \\
\text { in percent }\end{array}$ & $\begin{array}{l}\text { Correlation } \\
\text { coefficient }\end{array}$ \\
\hline \multicolumn{4}{|c|}{$\begin{array}{c}\text { Equation based on contributing drainage area (A) } \\
\text { and average annual precipitation (PR) }\end{array}$} \\
\hline$Q_{a}=0.0021 A^{0.88} P_{P R}^{1.19}$ & 45 & 96 & 0.95 \\
\hline \multicolumn{4}{|c|}{ Equation based on channel width (WIDTH) } \\
\hline$Q_{a}=0.00046$ WIDTH $^{2.42}$ & 20 & 117 & .93 \\
\hline
\end{tabular}

Table 5.--Applicable range of the estimation relations

\begin{tabular}{lcccc}
\hline & Mean & Average \\
& basin & annual & Basin \\
Region and & Drainage & elevation, & precip- slope, & Channel \\
equation & area, in & in feet above & itation, in feet & width, \\
\hline
\end{tabular}

Mountainous Regions

$\begin{array}{llllll}\text { Peak flows } & 0.52-3,465 & 3,700-11,100 & 12-55 & -- & 2-180 \\ \text { Annual flow } 6.30-3,465 & 5,000-10,800 & 14-55 & -- & 12-180\end{array}$

Plains Region

Peak flows $0.04-5,270 \quad \ldots \quad-115-1,620 \quad 6-120$

Annual flow $0.69-5,270 \quad$-- $\quad 7-22 \quad$-- $\quad 5-120$

High Desert Region

$\begin{array}{llllll}\text { Peak flows } & 1.26-1,178 & -- & 7-17 & -- & 3-60 \\ \text { Annual flow } 0.69-5,270 & -- & 7-22 & -- & 5-120\end{array}$




\section{Correlation with Nearby Gaged Streams}

In the Mountainous Regions, where streamflow occurs mainly from snownolt and there is relatively low variability of annual and seasonal runoff, an alternative to estimating runoff characteristics by regression is to correlate the discharge of an ungaged stream to the discharge of one or more nearby gaged streams. The gaged streams need to be located in basins having characteristics (drainage area, elevation, and aspect) similar to those of the ungaged basin. Streamflows from both gaged and ungaged basins need to be virtually unaffected by storage reservoirs and diversions.

\section{Mean Annual Flow}

Riggs (1969) describes a procedure for estimating mean annual flow by measuring the discharge of the ungaged stream near mid-month each calendar month for a year. These measured discharges are related to concurrent daily mean discharges at a nearby streamflow-gaging station using a separate relation of 45-degree slope for each month. The monthly mean flow at the gaged site is transferred though the appropriate relation to obtain an estimate of the monthly mean at the ungaged site. The annual mean flow for the year is computed from the 12 monthly means; it can be adjusted to an estimate of the mean annual flow on the basis of records for several nearby gaging stations. For a step-by-step description of the procedure, the reader is referred to Riggs (1969).

\section{Mean Monthly Flow}

Regression equations were investigated as a possible means of estimating mean monthly streamflows; however, on a statewide basis no useful relations were determined. If mean monthly streamflows are to be estimated, use of data for one or more gaged streams in the vicinity of the ungaged basin is desirable. The procedure is as follows:

Using the regression relations in this report, or the method of monthly measurements described by Riggs (1969), an estimate of mean annual flow is obtained for the ungaged site. Average monthly flows, expressed in percent of annual flow, are determined for each of the nearby gaged basins. The overall average percentage for each month is computed for the gaged sites, and these averages are multiplied by the estimate of mean annual flow to determine the estimated mean monthly streamflows at the ungaged site.

\section{Flood Characteristics at Gaged Sites with Short Records}

If streamflow characteristics are needed for a site that has been gaged, generally the station record is used--provided the period of record is sufficient to adequately define the values. However, when the period of record is relatively short, the distribution of peak discharges at the station may not be representative of the long-term flood history for the site. T'is is because a short period of record has the possibility of occurring within either a wet or dry climatic cycle. On the basis of the 
author's experience working with flood data, and a time-error analysis by Wahl (1970), this is especially possible for Wyoming streams having records for less than about 15 years for the Mountainous Regions and about 25 years for the Plains and High Desert Regions.

If the station record is considered to be relatively short and subject to error from a wet or dry climatic cycle, a weighting method (Sauer, 1974) may be used to provide a more accurate estimate of flood frequency at a gaged site on an unregulated stream. The method weights the peak discharge computed from the station flood frequency with the peak discharge estimated from the regional regression equation according to their respective years of record. The equation used for the weighting method is:

$$
Q_{t(w)}=\frac{Q_{t(s)^{N}+Q_{t}(r)^{E}}}{N+E}
$$

where $Q_{t(w)}=$ the weighted peak discharge, in cubic feet per second, for the recurrence interval of t-years;

$Q_{t(s)}=$ the station value of the flood based on the historical record, in cubic feet per second, for the recurrence interval of $t$-years;

$N=$ the number of years of station data used to compute $Q_{t}(s)$; $Q_{t(r)}=$ the regression estimate of the peak discharge, in curbic feet per second, for the recurrence interval of t-years; and

$E=$ the equivalent years of record for $\left.Q_{t} r\right)=10$ years (lased on recommendation by the U.S. Water $r$ Resources Council $(1981$, p. 21) for the 100-year peak discharge, whicl for the purposes of this report is assumed applicable to other recurrence intervals).

\section{Example Applications}

Procedures for estimating streamflow characteristics are given in the following examples:

Example A. Basin-characteristics method--Mountainous Regions

An estimate of the 100-year peak discharge is needed for the preliminary design of a bridge. The estimate is needed immediately; time is insufficient to make a field visit to obtain channel measurements at the proposed site. The contributing drainage area is 126 square miles, and the mean rasin elevation is 8,350 feet above sea level, both measured from maps. From flate $1 \mathrm{~b}$, average annual precipitation for the basin is determined to be 20 inches. The equation (from table 1) based on drainage area and mean basin elevation for $\mathrm{P}_{100}$ in the Mountainous Regions is:

$$
P_{100}=9.63 A^{0.77}\left(\frac{\text { ELEV }}{1,000}\right)^{0.85} .
$$


Substituting $A=126$ square miles and ELEV $=8,350$ feet,

$$
\begin{aligned}
P_{100} & =9.63(126)^{0.77} \frac{8,350}{1,000}^{0.85} \\
& =2,420 \text { cubic feet per second. }
\end{aligned}
$$

The equation based on contributing drainage area and average precipitation is:

$$
\mathrm{P}_{100}=40.7 \mathrm{~A}^{0.76} \mathrm{PR}^{0.13} \text {. }
$$

Substituting $A=126$ square miles and $P R=20$ inches per year,

$$
\begin{aligned}
P_{100} & =40.7(126)^{0.76}(20)^{0.13} \\
& =2,370 \text { cubic feet per second. }
\end{aligned}
$$

It is decided to use an average of the two results, determined as:

$$
\frac{(2,420+2,370)}{2}=2,400 \text { cubic feet per second. }
$$

Example B. Basin-characteristics method--Plains Region

An estimate is needed of the 50-year peak discharge for a tributary of Shawnee Creek at the site shown in figure 13. The basin is located about 12 miles southeast of Douglas (plate 1d). The drainage area is 2.12 square miles, and the basin slope is determined as follows: Length of 100-foot contour intervals in the basin ( $\mathrm{fig} .13$ ) is $14.9 \mathrm{miles}$; therefore, basin slope is :

$S_{B}=\frac{14.9(100)}{2.12}=703$ feet per mile.

The equation (from table 2) based on drainage area and basin slope is:

$$
P_{50}=112 A^{0.58 A^{-0.05}} S_{B}^{0.23} G_{f} \text {. }
$$

From plate 1d, the geographic factor $\left(G_{f}\right)$ is 1.4 . Substituting $A=2.12$ square miles, $S_{B}=703$ feet per mile, and $G_{f}=1.4$ :

$$
\begin{aligned}
P_{50} & =112(2.12)^{0.58(2.12)^{-0.05}}(703)^{0.23}(1.4) \\
& =1,080 \text { cubic feet per second. }
\end{aligned}
$$




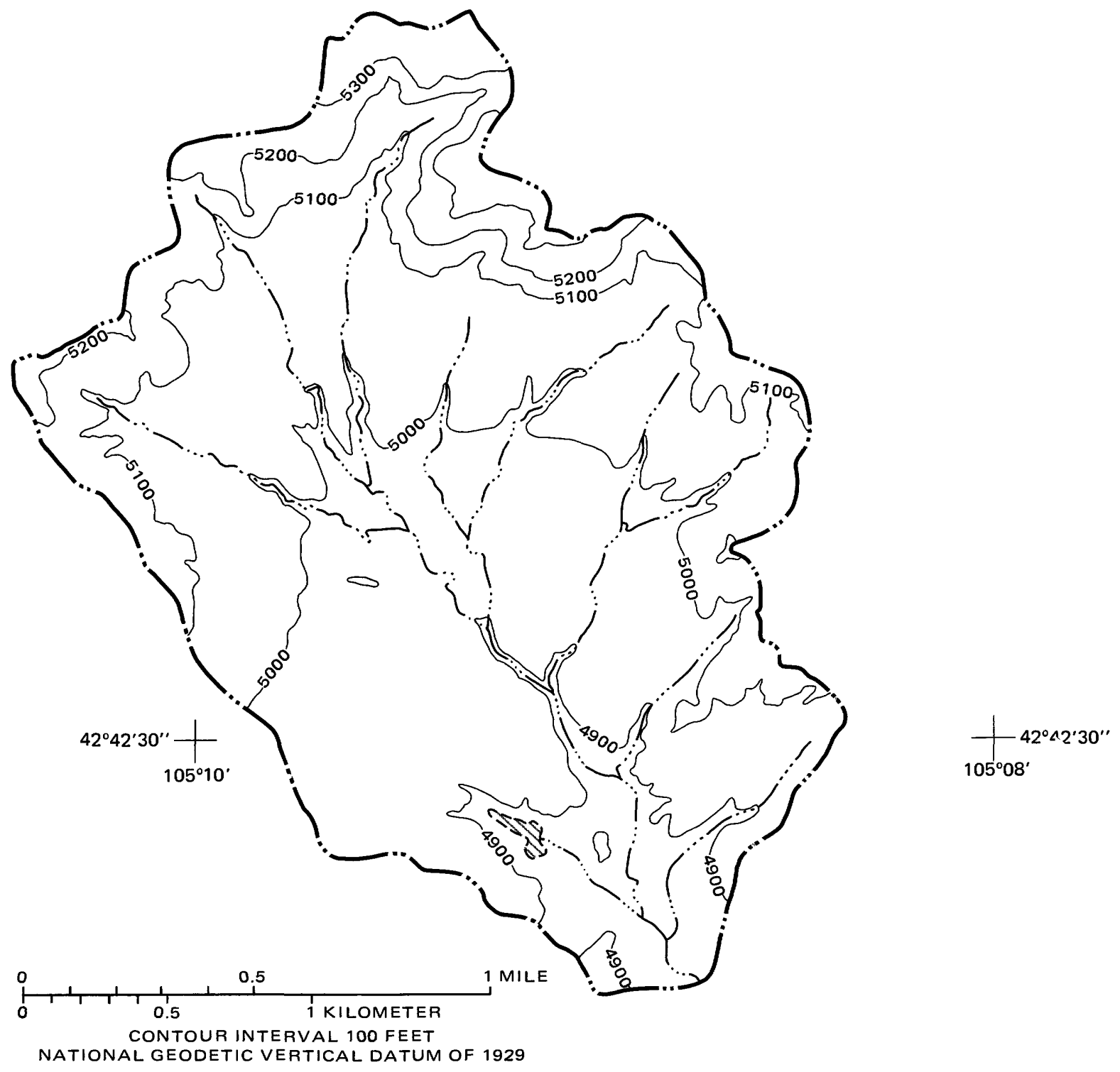

Figure 13.--Drainage basin for tributary of Shawnee Creek near Douglas. 
Example C. Comparison of basin-characteristics and channel-geometry methods

A structure is to be built on a tributary to the New Fork River near the site shown in figure 12. The ungaged stream is located in the High Desert Region about 16 miles east of Big Piney (plate 1d). The design is to be based on a peak discharge having a 25-year recurrence interval. The channel width is measured at several sections and averages 12 feet. The drainage area measures 10.7 square miles, average annual precipitation as shown by plate $1 \mathrm{~b}$ averages 9 inches, and the geographic factor as shown by plate $1 \mathrm{~d}$ is 0.6 .

By use of the equations from table 3, the basin-characteristics method indicates:

$$
\begin{aligned}
& P_{25}=19.4 A^{0.53 A^{-0.03} P R^{0.98} G_{f}} \\
& =19.4(10.7)^{0.53(10.7)^{-0.03}}(9)^{0.98}(0.6) \\
& =323 \text { cubic feet per second. }
\end{aligned}
$$

The channel-geometry method indicates:

$$
\begin{aligned}
P_{25} & =47.3 \text { WIDTH }^{1.06} G_{f} \\
& =47.3(12)^{1.06}(0.6) \\
& =395 \text { cubic feet per second. }
\end{aligned}
$$

The channel-geometry method yields a slightly greater estimated peak discharge than the basin-characteristics method. It is decided to use an average of the two results, determined as:

$$
\frac{(323+395)}{2}=359 \text { cubic feet per second. }
$$

Example D. Drainage is situated in more than one hydrologic region

If parts of one drainage area lie in two separate hydrologic regions, a weighted averaging technique may be used to estimate the flow characteristics. An estimate is made for each region assuming the drainage area is contained entirely within that region. The average is computed by weighting each estimate with the proportion of drainage area contained in the corresponding hydrologic region.

A stream has a drainage area of 54 square miles, of which 40 square miles lie in the Mountainous Region and 14 square miles lie in the Plains Region. That part of the basin in the Mountainous Region has an average 
annual precipitation of 20 inches. The proposed structure needs to be able to withstand a 100-year flood. Equations from table 1 are used to estimate the 100-year peak discharge for the Mountainous Regions, thus:

$$
\mathrm{P}_{100}=40.7 \mathrm{~A}^{0.76} \mathrm{PR}^{0.13} \text {. }
$$

Substituting $A=54$ square miles and $P R=20$ inches per year,

$$
\begin{aligned}
P_{100} & =40.7(54)^{0.76}(20)^{0.13} \\
& =1,250 \text { cubic feet per second. }
\end{aligned}
$$

That part of the drainage basin in the Plains Region has a geographic factor of 1.2 , and a basin slope of 500 feet per mile. From the Plains Rerion equations of table 2, the 100-year peak discharge is:

$$
\begin{aligned}
& P_{100}=130 A^{0.58 A^{-0.05}} S_{B}^{0.25} G_{f} \\
& =130(54)^{0.58(54)^{-0.05}(500)^{0.25}(1.2)} \\
& =4,910 \text { cubic feet per second. }
\end{aligned}
$$

The weighted average of $\mathrm{P}_{100}$ is determined as:

$$
\begin{aligned}
P_{100} & =(1,250) \frac{40}{54}+(4,910) \frac{14}{54} \\
& =2,200 \text { cubic feet per second. }
\end{aligned}
$$

\section{Example E. Mean monthly streamflows}

Estimates of mean monthly flows are needed for an ungaged stream in the mountains southwest of Encampment. Runoff from the area is primarily snowmelt, and the runoff pattern of a nearby gaged stream, Encampment River (streamflow-gaging station 06623800), is fairly consistent from year to year. The ungaged stream (drainage area is 40.0 square miles, average annnual precipitation is 28 inches) has basin characteristics similar to the upstream drainage of the Encampment River (drainage area is 72.7 square miles, average annual precipitation is 26 inches).

The regime of the ungaged stream is believed to be similar to that of the Encampment River. Mean monthly flows of the Encampment River at station 06623800 are shown in table 6 , expressed both as a rate and percentage of the mean annual flow. The mean monthly flows of the ungaged stream are assumed to occur in the same proportions as those of the Encampment River. Mean annual flow can be estimated either by a regression equation or by the mont.hly measurement method. The monthly measurement method requires 12 months to complete, which is a greater time period than is available for the project design. Therefore, it is decided to use one of the regression equations to estimate mean annual flow. 
The equation (from table 1) for estimating mean annual flow in the Mountainous Regions, based on drainage area and average annual precipitation is:

$$
Q_{a}=0.013 A^{0.93} \mathrm{PR}^{1.43}
$$

where $A=40.0$ square miles,

$P R=28$ inches per year, and

$Q_{a}=47$ cubic feet per second.

The mean monthly flows at the ungaged site are then determined, as srown in table 6 , by multiplying the respective percentage for each month by the product of the mean annual flow times 12 months.

Table 6.--Summary of data and results for estimating mean monthly flow

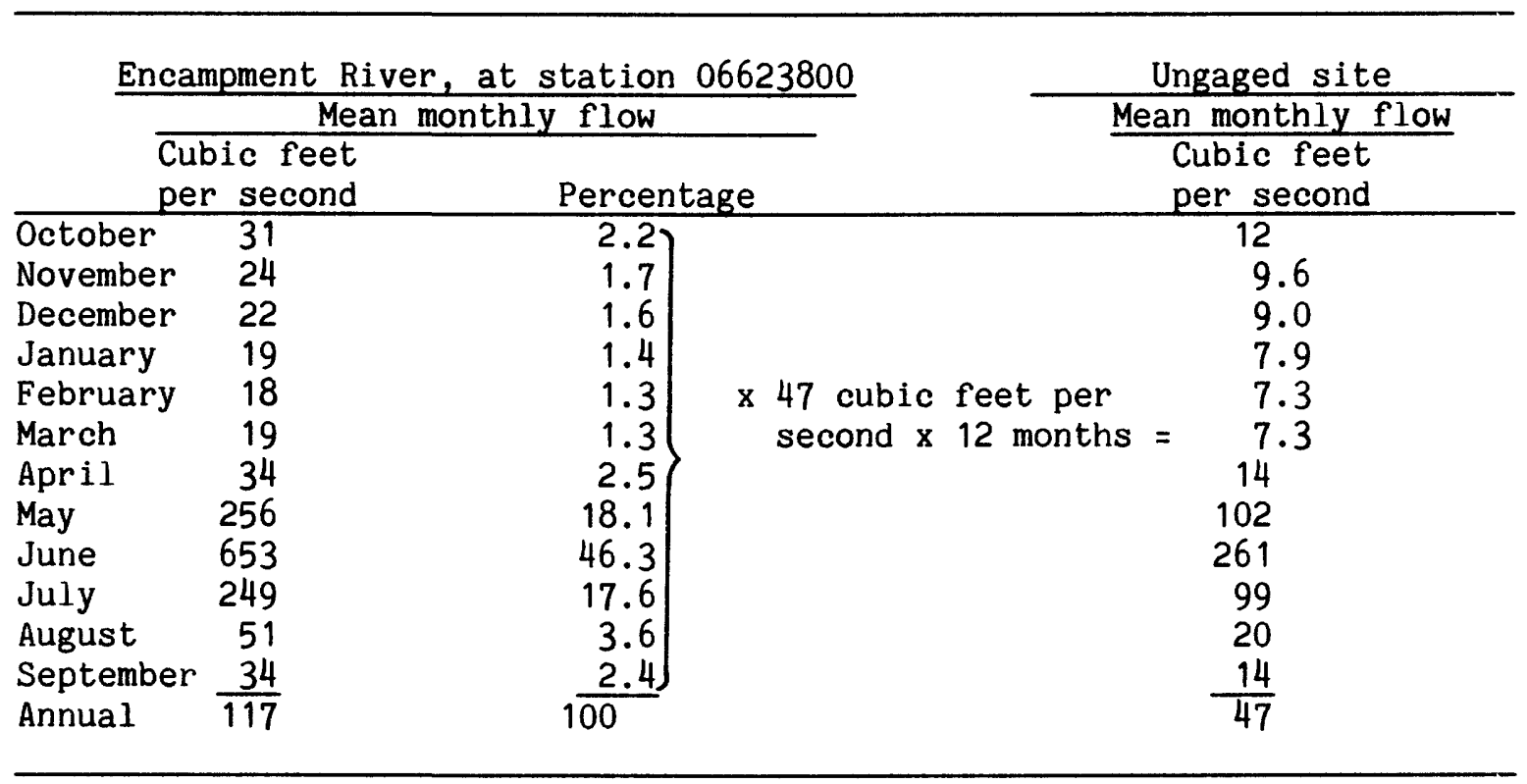

Example F. An ungaged site on a gaged stream

A structure is being designed for the Bear River at Evanston, and estimates of the 50- and 100-year peak discharges are needed. These flood characteristics at selected streamflow-gaging stations on the Bear River are plotted against drainage area in figure 14. Drainage area upstream from Evanston is computed and entered on the graph to give estimates of the 50- and 100-year peak discharges of 3,700 and 4,000 cubic feet per second, respectively. 


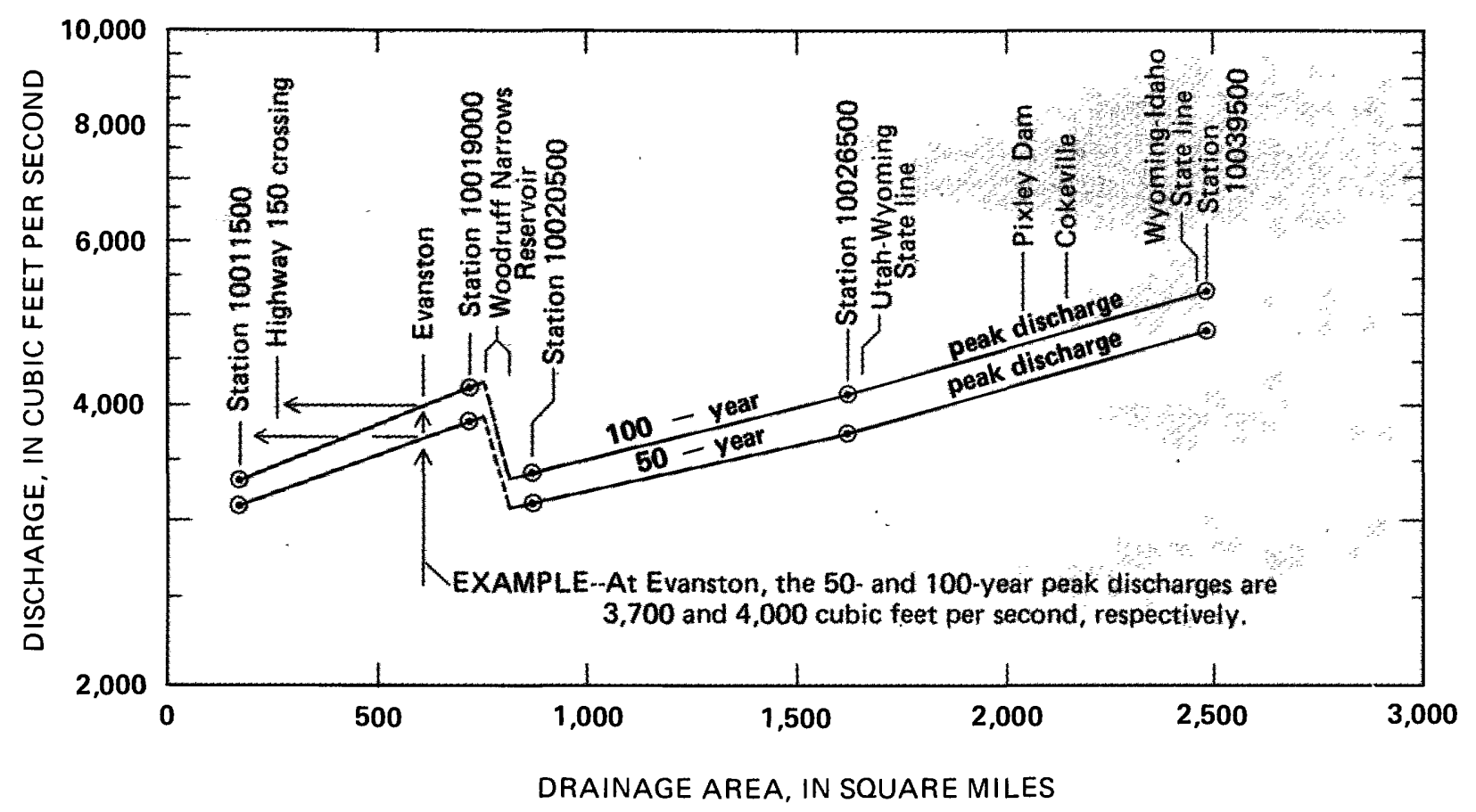

Figure 14.--Relation of peak discharge to drainage area for the Bear River. 


\section{HISTORICAL FLOODS IN WYOMING}

The flow characteristic most frequently needed for planning and design of stream-related structures is peak discharge. The 100-year flood generaliy is used for identification of flood-prone areas and in the design of important or expensive structures. The 200- and 500-year floods may be considered in situations where there is potential danger to human life or property. Minor structures, such as culverts on county roads, frequently are designed to pass 10 - or 25-year floods.

Lay persons who observe annual snowmelt occurring in the perennial streams of mountainous areas, as compared to the usually dry stream channels of the plains and desert areas, may conclude that mountainous streams have the highest floodflows. Just the opposite is true. For similar-sized drainage areas or channel widths, streams of the Plains and High Desert Regions have much larger floods than streams of the Mountainous Regions. Many of the large floods in plains and desert areas are not observed because they occur in remote areas and at night as a result of late-afternoon or evening convective storms.

Streams in Wyoming may have large floods, even though only minimal or no flows may have been observed for many years. When a large flood does orcur, it can cause loss of 1 ife and great destruction, as in the case of the August 1, 1985, flood of Dry Creek in Cheyenne (Druse and others, 1986). Twelve deaths, 70 injuries, and $\$ 61.1$ million in damage were the result of flooding caused by a massive storm that drenched downtown Cheyenne with as much as 7 inches of rain and hail between approximately $6 \mathrm{p.m}$. and $10 \mathrm{p} . \mathrm{m}$. (figs. 15 and 16).

To illustrate that large floods have occurred in Wyoming, plots that show the relation between known peak discharge and corresponding drainage area are presented for each of the three hydrologic regions (figs. 17-19). The figures include large floods at miscellaneous sites, as well as the largest peaks of record at streamflow-gaging stations. Also shown on the figures are: (1) The relation of 100-year peak discharge to drainage area, computed using equations from tables $1-3 ;(2)$ the enveloping line defined by maximum observed discharges; and (3) the enveloping line for maximum discharges of the Rocky Mountain area (Crippen and Bue, 1977). 


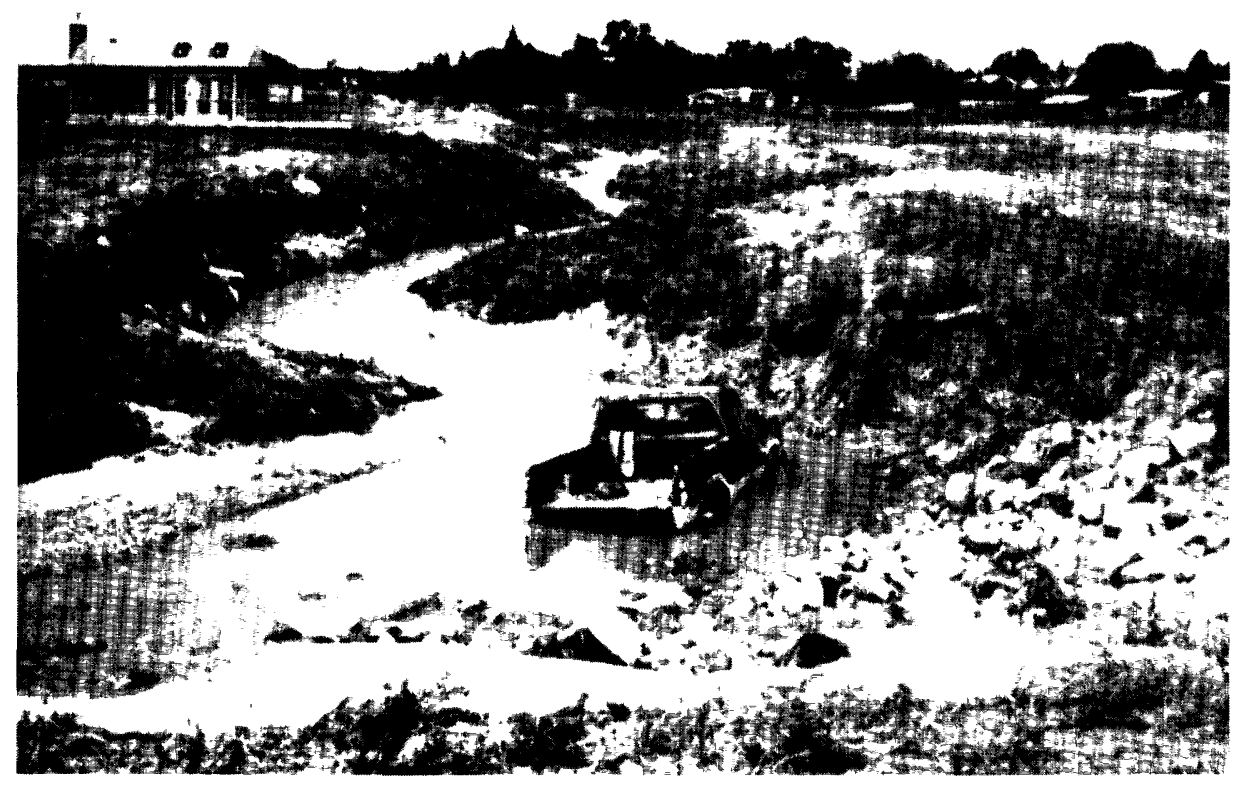

Figure 15.--Dry Creek in north Cheyenne the day after the flood of August 1, 1985. View is upstream.

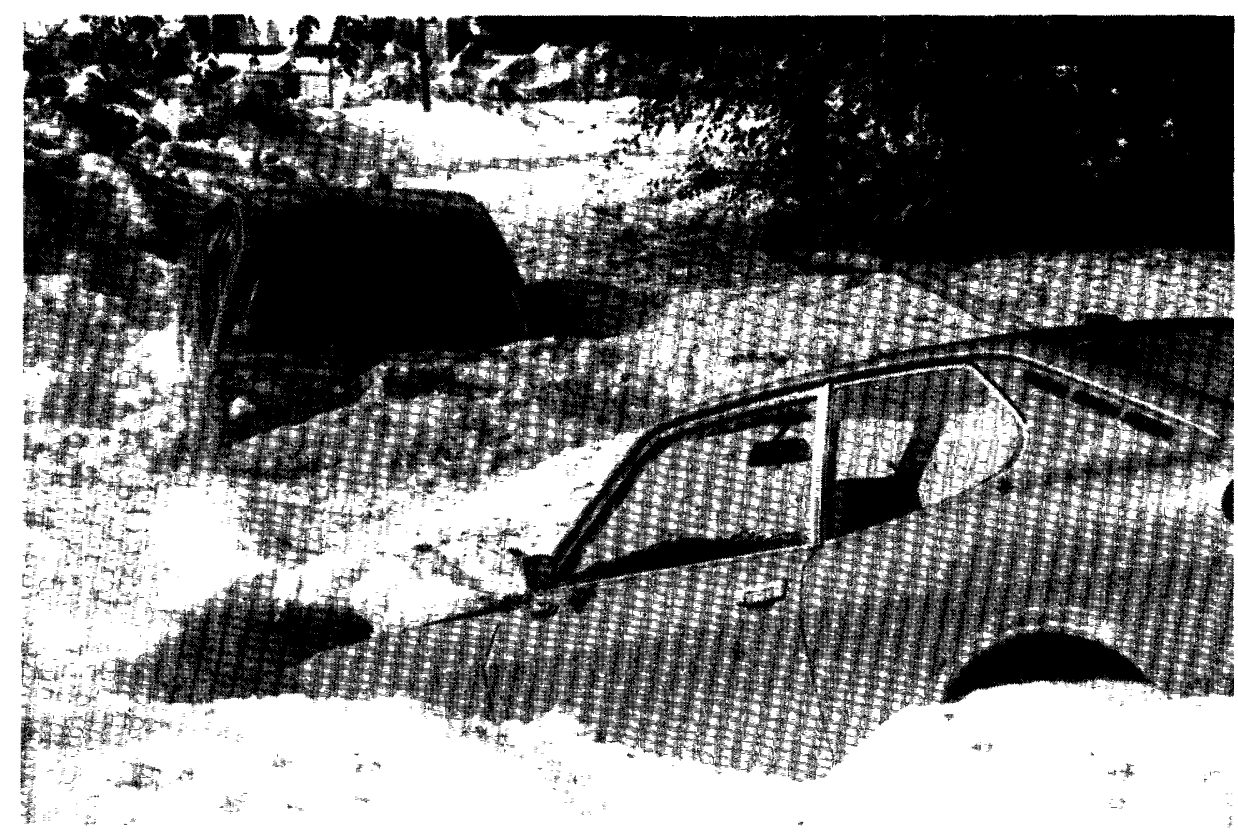

Figure 16.--Hail accumulation in a low area of Cheyenne following the flood of August 1, 1985. Photograph courtesy of Mark Junge. 


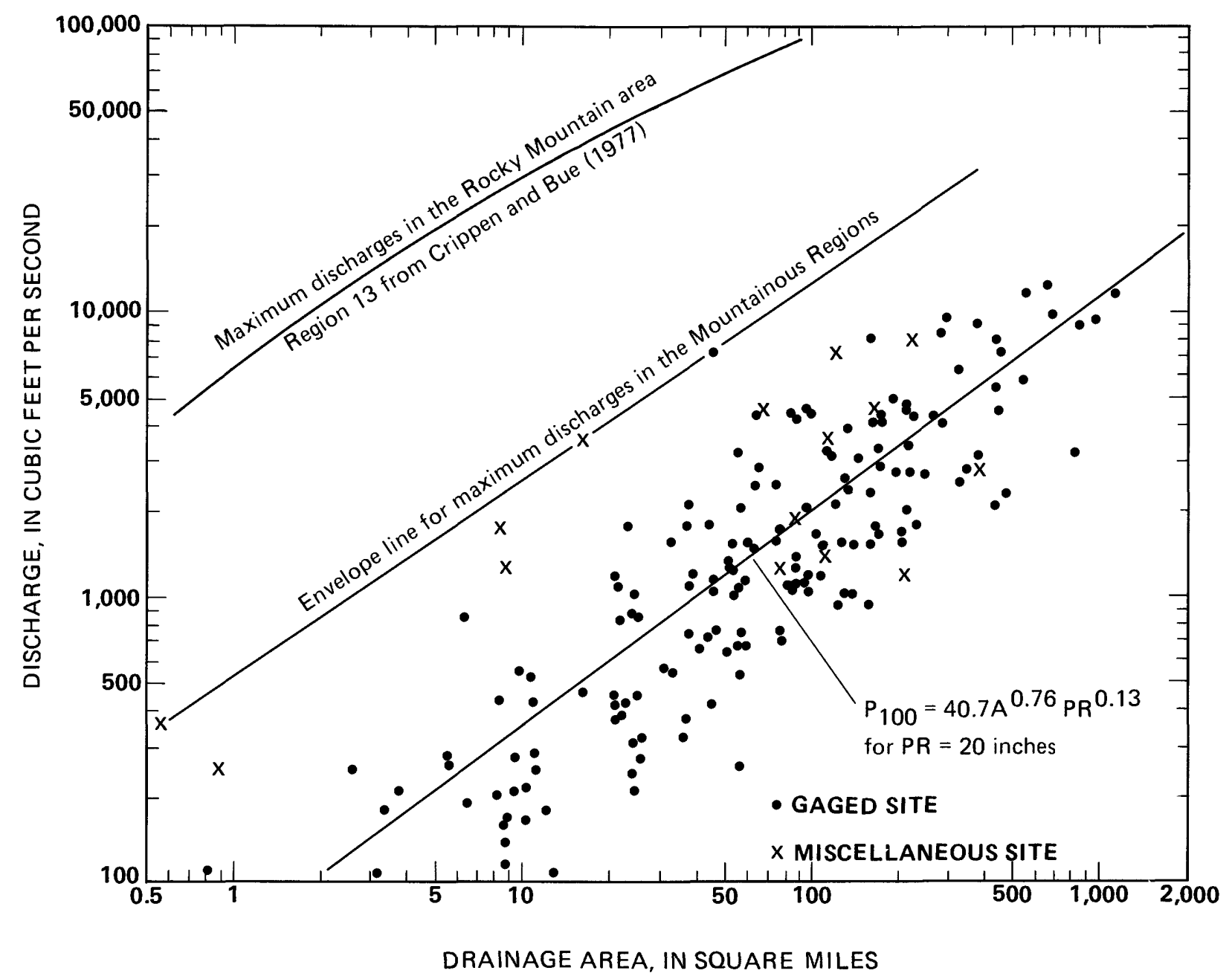

Figure 17.--Relation of maximum known peak discharge to drainage area for the Mountainous Regions. 


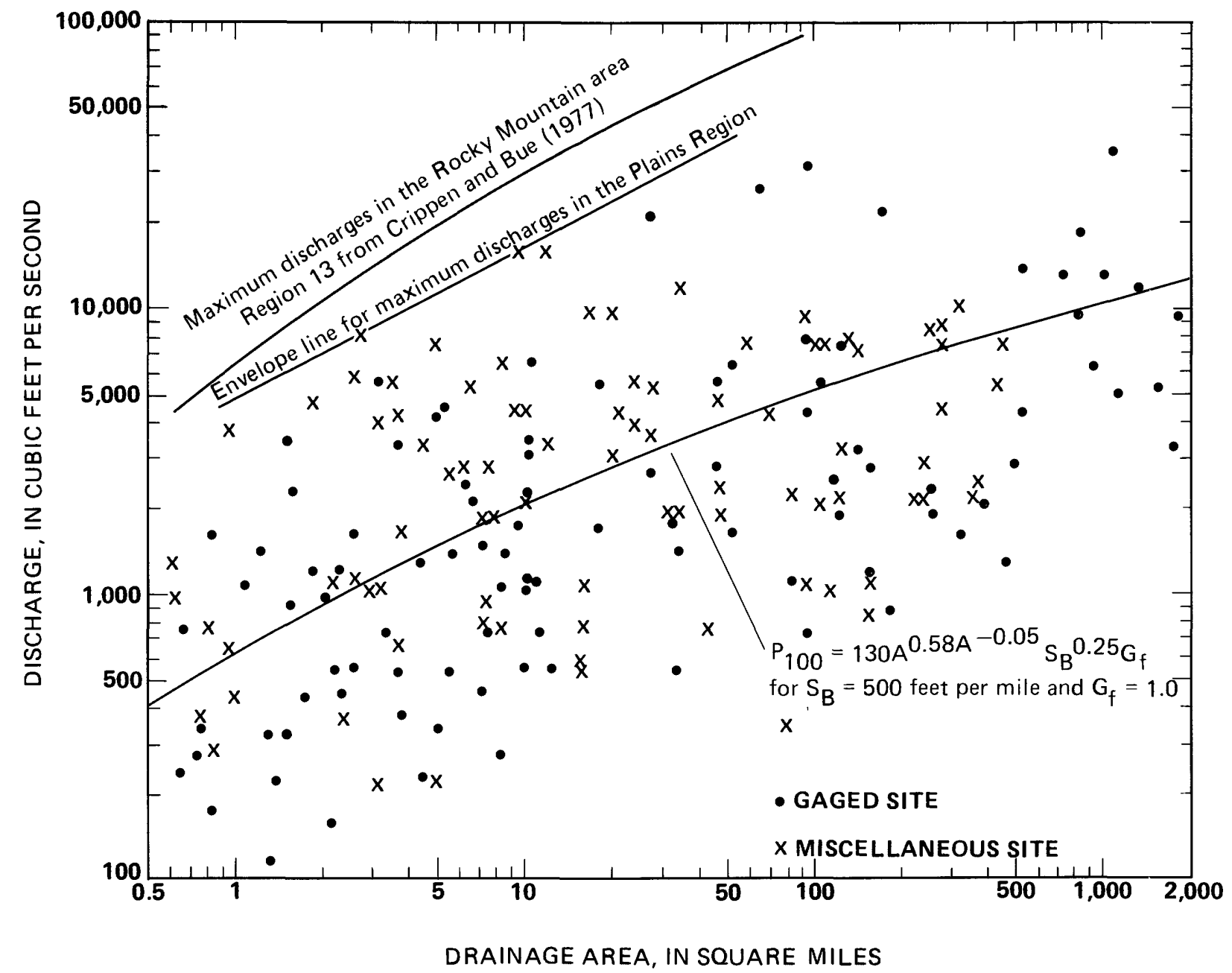

Figure 18.--Relation of maximum known peak discharge to drainage area for the Plains Region. 


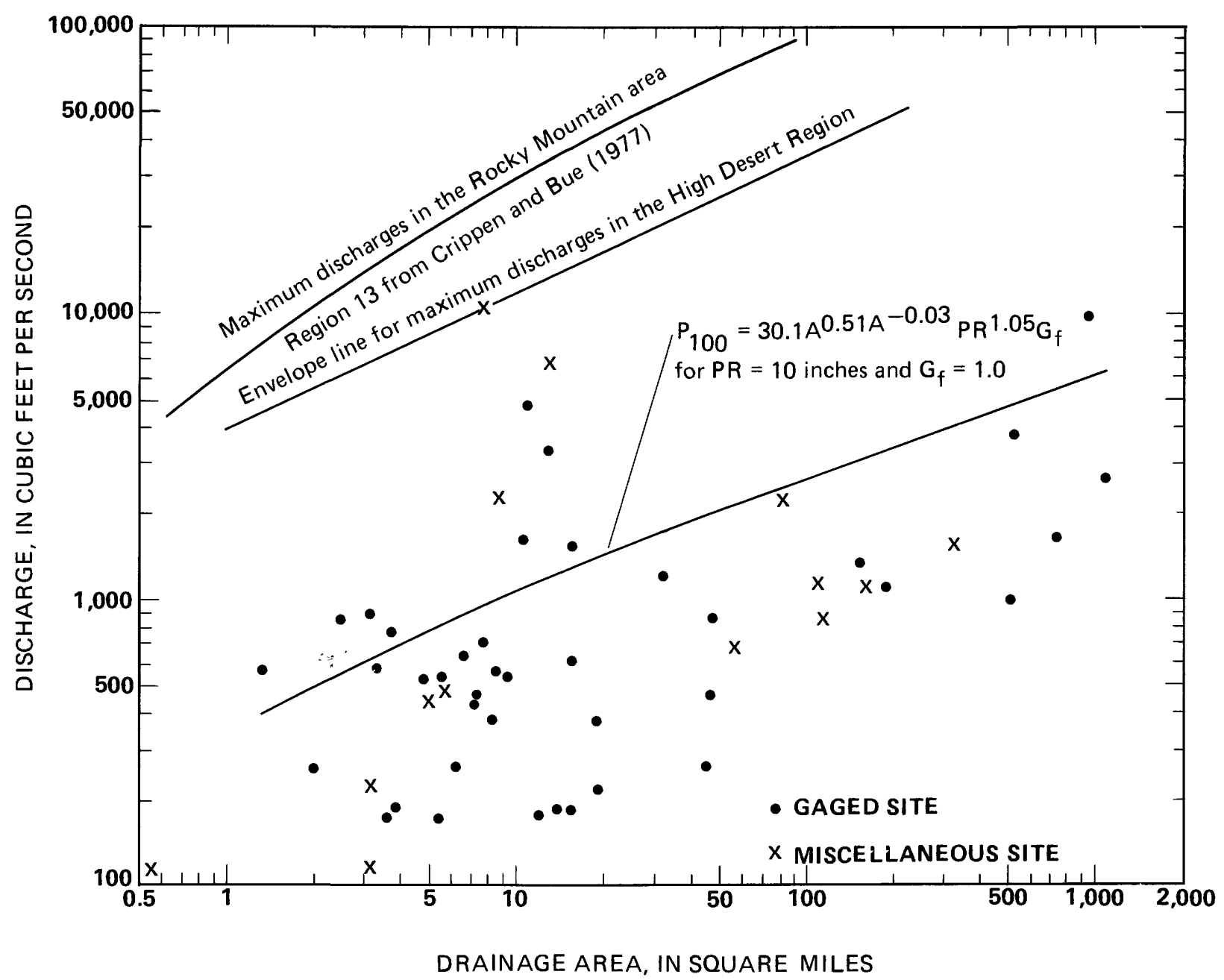

Figure 19.--Relation of maximum known peak discharge to drainage area for the High Desert Region. 


\section{SUMMARY}

Streams were important in the early development of Wyoming, which included trapping, gold mining, agriculture, and logging. They continue tc be a vital natural resource for the above uses and for tourism and the energymineral industry. Streams have various characteristics throughout the State due to large differences in climate, geology, and topography. Perennial streams with source drainage areas in the mountains provide the most runoff in Wyoming. However, for similarly-sized drainage areas or channel widths, streams draining the plains and deserts produce much larger peak flows than streams draining the mountains.

Streamflow characteristics are available for several hundred sites in Wyoming where streamflow gages have been operated. Time and cost constraints prevent the installation and operation of gages at every site where data may be needed. Methods of estimating streamflow characteristics at ungaged sites have been developed by using data at gaged sites.

Peak-flow characteristics at streamflow-gaging stations were determined by fitting the data to the Pearson Type III probability distribution using refined procedures recommended by the U.S. Water Resources Council. The procedures include use of (1) a generalized skew coefficient, which improves the accuracy of peak-flow characteristics for gages with short records, and (2) use of an historical adjustment, which allows data from outside the geged period of record to be used in defining the peak-flow characteristics. The refinements have improved peak-flow determinations, especially for gaging stations in the plains and desert areas where streams are subject to high annual variability.

A large data base is available for defining mean annual runof $f$ of perennial streams draining mountainous areas of the State; however, a shortage of these data exists for small streams in the plains and desert areas. To help overcome this deficiency, the records of 21 seasonal gages, which were operated on small streams in the plains and desert areas during the principal rainfall months of May through September of 1963-73, were used. These partial-year data were adjusted to provide an estimated mean annual flow for each of the sites on the basis of a comparison with year-round records for similar streams. Peak-flow characteristics of these 21 seasonal gages also were used.

Regression equations are presented in this report for estimating peak-flow characteristics and mean annual flows of ungaged Wyoming streams. The equations were developed through an analysis of data for gaged basins that were considered to be representative of natural conditions. Records for 361 streamflow-gaging stations were used in the final analysis.

The regression analysis used equations that express flow characteristics in relation to either basin characteristics or channel-geometry features. The basin characteristics tested in the regression analysis included 10 physical and three climatic variables. Only contributing drainage area, mean basin elevation, average annual precipitation, and basin slope were determined to be significant to various regression relations defining the flow characteristics. The channel-geometry features tested included the width, depth, and width-to- 
depth ratio of the stream channel, and measurements of the sedinent composition of the streambed and banks. Only channel width was found to be significant for estimating the flow characteristics. The basin characteristics may be measured or determined from maps; whereas, the channel width must be measured on-site.

Due to diverse climatic and physical conditions that cannot be wholly defined by numeric variables, it was necessary to develop separate sets of estimation equations for three regions of different hydrologic settings. The three regions are: (1) The Mountainous Regions, which include the major mountainous areas of the State where snowmelt has a dominant influence on streamflows, (2) the Plains Region, which includes the northern and eastern plains and deserts where runoff from convective storms has a significant influence on peak flows, and (3) the High Desert Region, which includes the south-central and southwestern plains and desert areas where widespread general rainstorms and snow have a major effect on peak flows.

For the Mountainous Regions, the regression model uses equations of exponential form, which plot as straight lines on logarithmic graph paper. However, for the Plains and High Desert Regions, a curvilinear model was determined to be more applicable for estimating peak flows using basin characteristics. The curvilinear model uses equations of double-exponential form, which plot as curved lines on logarithmic graph paper. The curvilinear model has the advantage of converging toward zero runoff for zero drainage area while still fitting the data points for the complete range of drainage sizes for the gaged streams. The need for a curvilinear model is the result of a decrease in precipitation intensity and an associated decrease in unit runoff as drainage area increases. The intensity decreases with basin size as the most dominant type of storm-runoff event changes from convective storm * to general rainstorms and snowmelt.

Regression analysis also was investigated as a method for estimating monthly flows; however, it was determined that local differences in runoff characteristics complicated the results. Estimates of monthly streamflows can be more accurately made by correlating with data for nearby gaged streams.

Examples are provided to familiarize users with application of the estimation methods. In addition, a summary of historical floods that have occurred both at streamflow-gaging stations and at miscellaneous sites is presented. 


\section{REFERENCES}

Alyea, J.D., 1980, Precipitation survey of Wyoming: Unpublished report: on file in Cheyenne office of the U.S. Geological Survey, Water Resources Division, $38 \mathrm{p}$.

Coulant, C.G., 1899a, The history of Wyoming from the earliest known discoveries, volume 1: Laramie, Wyo., Chaplin, Spafford \& Mathison, Printers, $712 \mathrm{p}$.

$1899 \mathrm{~b}$, The history of Wyoming from the earliest known discoveries, volume 2: Laramie, Wyo., Chaplin, Spafford \& Mathison, Printers, Reprinted 1966, Argonaut Press, Ltd., New York, 736 p.

Craig, G.S., Jr., and Rankl, J.G., 1978, Analysis of runoff from small drainage basins in Wyoming: U.S. Geological Survey Water-Supply Paper 2056, 70 p.

Crippen, J.R., and Bue, C.D., 1977, Maximum floodflows in the conterminous United States: U.S. Geological Survey Water-Supply Paper 1887, 52 p.

Druse, S.A., Cooley, M.E., Green, S.L., and Lowham, H.W., 1986, Flood of August 1, 1985, in Cheyenne, Wyoming: U.S. Geological Survey Hydrolcgic Investigations Atlas HA-699, 2 sheets.

Lowham, H.W., 1976, Techniques for estimating flow characteristics of Wyom ing streams: U.S. Geological Survey Water-Resources Investigations Report $76-112,83 \mathrm{p}$.

1982, Streamflow and channels of the Green River basin, Wyoming: U.S. Geological Survey Water-Resources Investigations Report 81-71, 73 p.

National Oceanic and Atmospheric Administration, 1982, Monthly normals of temperature, precipitation, and heating and cooling degree days 1951-80: in Climatography of the United States: U.S. Department of Commerce, no. $\overline{81}, 14 \mathrm{p}$.

Omang, R.J., Parrett, Charles, and Hull, J.A., 1986, Methods for estimating magnitude and frequency of floods in Montana based on data through 1583: U.S. Geological Survey Water-Resources Investigations Report 86-4027, $85 \mathrm{p}$.

Osterkamp, W.R., 1977, Effect of channel sediment on width-discherge relations, with emphasis on streams in Kansas: Kansas Water Resources Board Bulletin 21, 25 p.

Osterkamp, K.R., and Hedman, E.R., 1982, Perennial-streamflow characteristics related to channel geometry and sediment in the Missouri River basin: U.S. Geological Survey Professional Paper 1242, 37 p.

Powell, J.W., 1878, Report on the lands of the arid region of the United States, with a more detailed account of the lands of Utah: 2nd edition, 1879, Washington, U.S. Government Printing office, 195 p.

Rankl, J.G., and Barker, D.S., 1977, Rainfall and runoff data from small basins in Wyoming: Wyoming Water Planning Program Report No. 17, 195 p. 
Rantz, S.E., 1982, Measurement and computation of streamflow: v. 1, Measurement of stage and discharge; v. 2, Computation of discharge: U.S. Geological Survey Water-Supply Paper 2175, $631 \mathrm{p}$.

Riggs, 1969, Mean streamflow from discharge measurements: International Association of Scientific Hydrology Bulletin XIV, no. 4, p. 95-110.

SAS (Statistical Analysis System) Institute, Inc., 1982, SAS user's guide, 1982 edition: Cary, N.C., SAS Institute, Inc., 584 p.

Sauer, V.B., 1974, Flood characteristics of Oklahoma streams: U.S. Geological Survey Water-Resources Investigations Report 52-73, 301 p.

Sauer, V.B., Thomas, W.O., Jr., Stricker, V.A., and Wilson, K.V., 1983, Flood characteristics of urban watersheds in the United States: U.S. Geological Survey Water-Supply Paper 2207, 63 p.

Schumm, S.A., 1960, The shape of alluvial channels in relation to sediment type: U.S. Geological Survey Professional Paper 352-B, 30 p.

Smith, H.N., 1947, Rain follows the plow - The notion of increased rainfall for the Great Plains, 1844-1888: Huntington Library Quarterly, San Marino Calif., The Huntington Art Gallery and Botanical Gardens, v. 10, p. 169-193.

Stegner, W.E. 1960, Beyond the 100th meridian - John Wesley Powell and the second opening of the West: Cambridge, Mass., The Riverside Press, $438 \mathrm{p}$.

U.S. Water Resources Council, 1979, A unified national program for flood plain management: Washington, D.C., 93 p.

1981, Guidelines for determining flood flow frequency: Hydrology Committee Bulletin 17B, $180 \mathrm{p}$.

Wahl, K.L., 1970, A proposed streamflow data program for Wyoming: U.S. Geological Survey open-file report, $44 \mathrm{p}$.

Wasden, D.J., 1973, From beaver to oil - A century in the developmert of Wyoming's Big Horn Basin: Cheyenne, Wyo., Pioneer Printing \& Stationary Co., $350 \mathrm{p}$.

Wolman, M.G., and Miller, J.P., 1960, Magnitude and frequency of forces in geomorphic processes: Journal of Geology, v. 68, no. 1, p. 54-74. 
Table 7a.--Streamflow stations used in the analysis

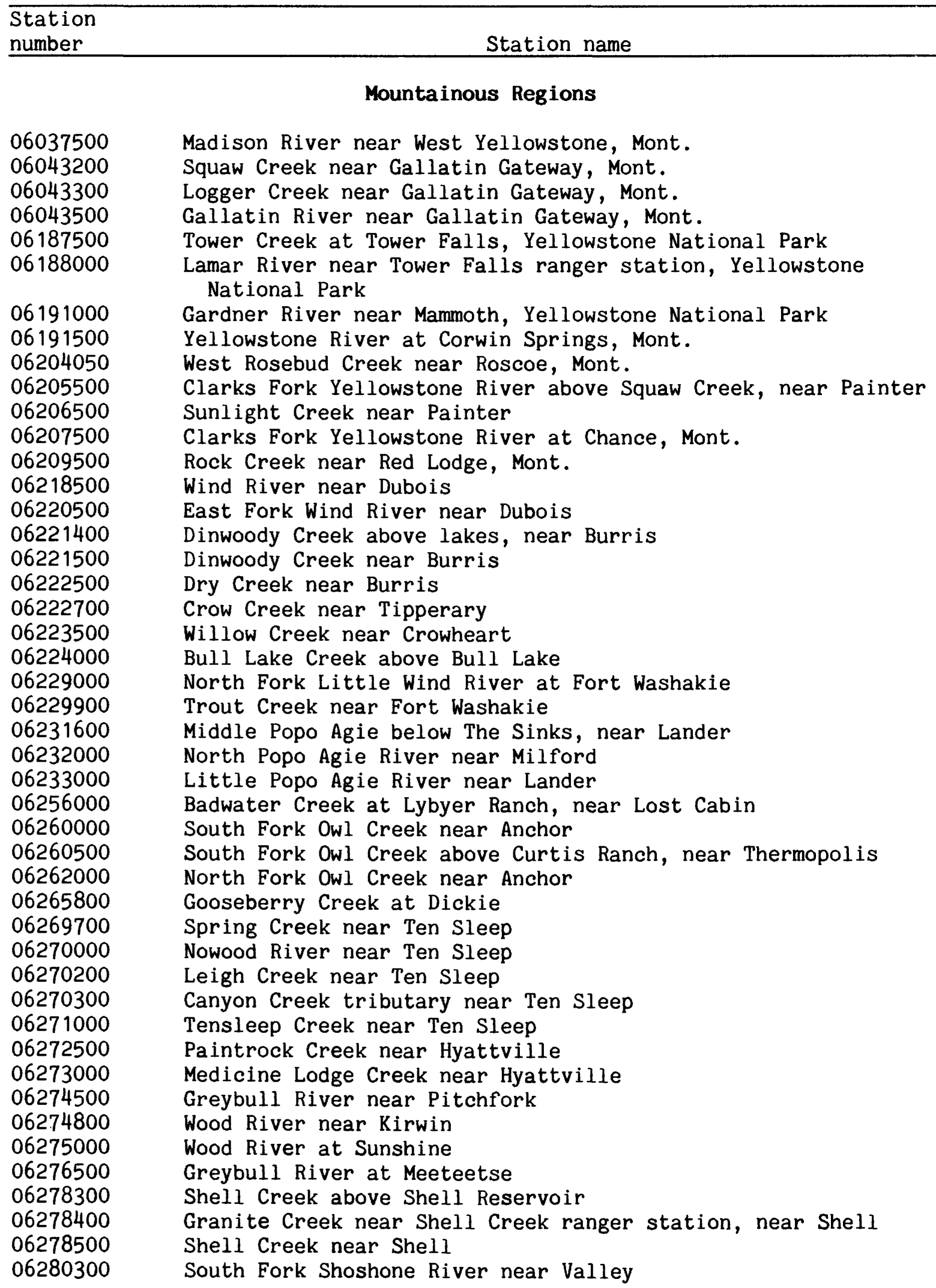


Table 7a.--Streamflow stations used in the analysis--Continued

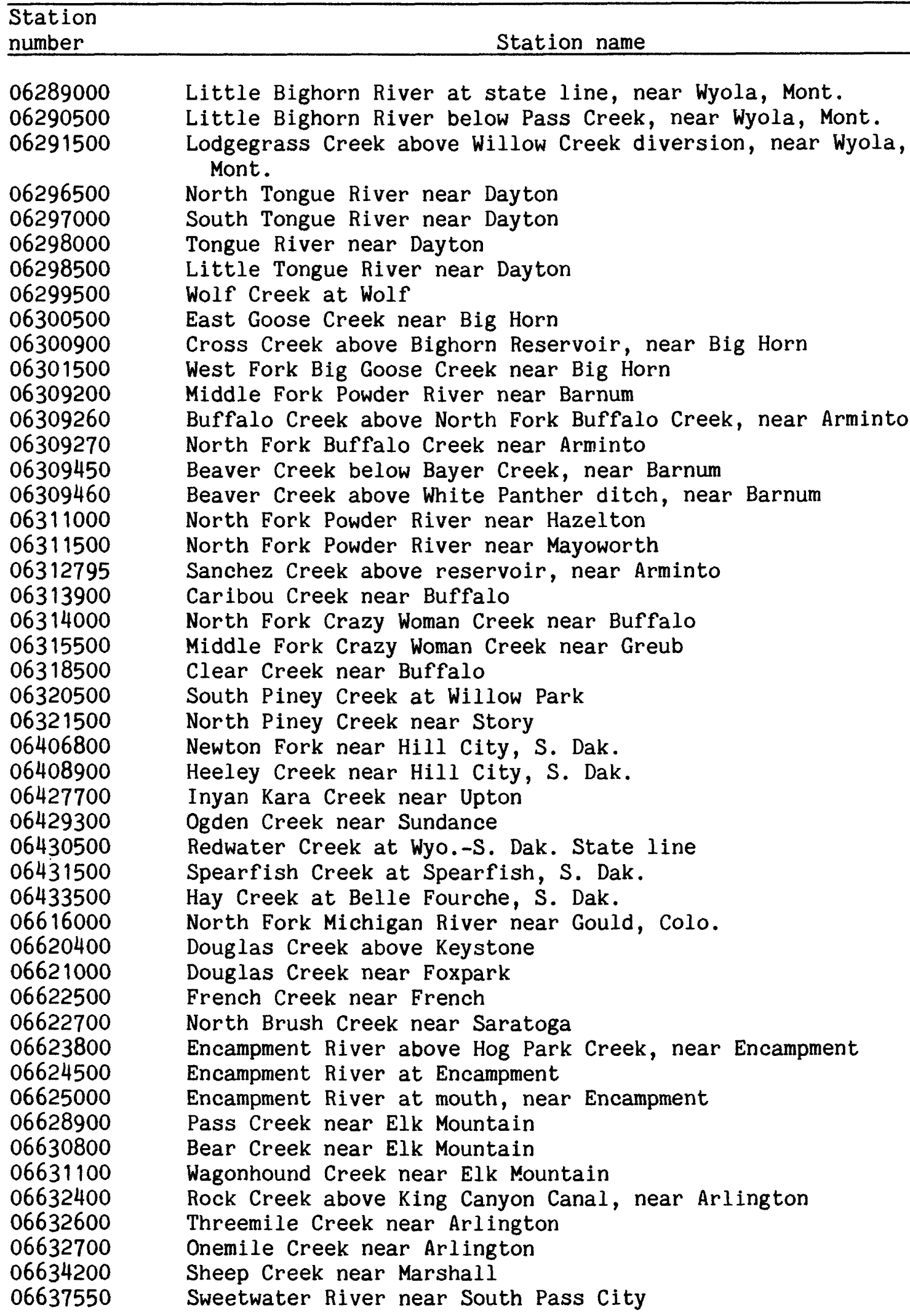


Table 7a.--Streamflow stations used in the analysis--Continued

\begin{tabular}{|c|c|}
\hline $\begin{array}{l}\text { Station } \\
\text { number }\end{array}$ & Station name \\
\hline $\begin{array}{l}06637750 \\
06638300 \\
06645150 \\
06646500 \\
06647500 \\
06647890 \\
06661000 \\
06661580 \\
06664500 \\
06667500 \\
06748200 \\
06748510 \\
06748530 \\
06748600 \\
06754500 \\
06755000 \\
09188500 \\
09189500 \\
09196500 \\
09198500 \\
09199500 \\
09201000 \\
09203000 \\
09204000 \\
09204500 \\
09205500 \\
09208000 \\
09210500 \\
09212500 \\
09214000 \\
09216527 \\
09217900 \\
09218500 \\
09220000 \\
09220500 \\
09223000 \\
09224000 \\
09226000 \\
09226500 \\
09227000 \\
09227500 \\
09228500 \\
09235600 \\
09241000 \\
09244500 \\
09245000 \\
09245500 \\
09251800 \\
09251900\end{array}$ & $\begin{array}{l}\text { Rock Creek above Rock Creek Reservoir } \\
\text { West Fork Crooks Creek near Jeffrey City } \\
\text { Smith Creek above Otter Creek, near Casper } \\
\text { Deer Creek at Glenrock } \\
\text { Box Elder Creek at Boxelder } \\
\text { Little Box Elder Creek near Careyhurst } \\
\text { Little Laramie River near Filmore } \\
\text { Sevenmile Creek near Centennial } \\
\text { Sybille Creek above Bluegrass Creek, near Wheatland } \\
\text { North Laramie River near Wheatland } \\
\text { Fall Creek near Rustic, Colo. } \\
\text { Little Beaver Creek near Idylwilde, Colo. } \\
\text { Little Beaver Creek near Rustic, Colo. } \\
\text { South Fork Cache La Poudre River near Rustic Colo. } \\
\text { Middle Crow Creek near Hecla } \\
\text { South Crow Creek near Hecla } \\
\text { Green River at Warren Bridge, near Daniel } \\
\text { Horse Creek at Sherman ranger station } \\
\text { Pine Creek above Fremont Lake, near Pinedale } \\
\text { Pole Creek below Little Half Moon Lake, near Pinedale } \\
\text { Fall Creek near Pinedale } \\
\text { New Fork River near Boulder } \\
\text { East Fork River near Big Sandy } \\
\text { Silver Creek near Big Sandy } \\
\text { East Fork at Newfork } \\
\text { North Piney Creek near Mason } \\
\text { La Barge Creek near La Barge Meadows ranger station } \\
\text { Fontenelle Creek near Herschler Ranch, near Fontenelle } \\
\text { Big Sandy River at Leckie Ranch, near Big Sandy } \\
\text { Little Sandy Creek near Elkhorn } \\
\text { Separation Creek near Riner } \\
\text { Blacks Fork near Robertson } \\
\text { Blacks Fork near Millburne } \\
\text { East Fork of Smiths Fork near Robertson } \\
\text { West Fork of Smiths Fork near Robertson } \\
\text { Hams Fork below Pole Creek near Frontier } \\
\text { Hams Fork at Diamondville } \\
\text { Henrys Fork near Lonetree } \\
\text { Middle Fork Beaver Creek, near Lonetree } \\
\text { East Fork Beaver Creek near Lonetree } \\
\text { West Fork Beaver Creek near Lonetree } \\
\text { Burnt Fork near Burntfork } \\
\text { Pot Creek above diversions, near Vernal, Utah } \\
\text { Elk River at Clark, Colo. } \\
\text { Elkhead Creek near Clark, Colo. } \\
\text { Elkhead Creek near Elkhead Colo. } \\
\text { North Fork Elkhead Creek near Elkhead, Colo. } \\
\text { North Fork Little Snake River near Encampment } \\
\text { North Fork Little Snake River near Slater, Colo. } \\
\text { Sal }\end{array}$ \\
\hline
\end{tabular}


Table 7a.--Streamflow stations used in the analysis--Continued

\begin{tabular}{|c|c|}
\hline $\begin{array}{l}\text { Station } \\
\text { number }\end{array}$ & Station name \\
\hline $\begin{array}{l}09253000 \\
09253400 \\
09254500 \\
09255000 \\
09255500 \\
09256000 \\
09257000 \\
09258000 \\
10010400 \\
10011500 \\
10012000 \\
10015700 \\
10019700 \\
10021000 \\
10027000 \\
10032000 \\
10040000 \\
10040500 \\
10041000 \\
10047500 \\
10058600 \\
10069000 \\
10128500 \\
13011500 \\
13011800 \\
13011900 \\
13018300 \\
13019220 \\
13019400 \\
13019500 \\
13020000 \\
13021000 \\
13022500 \\
13023000 \\
13023800 \\
13025500 \\
13027000 \\
13027200 \\
13029500 \\
13030000 \\
13030500 \\
13032000 \\
13038900 \\
13050700 \\
13050800\end{array}$ & $\begin{array}{l}\text { Little Snake River near Slater, Colo. } \\
\text { Battle Creek near Encampment } \\
\text { Slater Fork at Baxter Ranch, near Slater, Colo. } \\
\text { Slater Fork near Slater, Colo. } \\
\text { Savery Creek at upper station, near Savery } \\
\text { Savery Creek near Savery } \\
\text { Little Snake River near Dixon } \\
\text { Willow Creek near Dixon } \\
\text { East Fork Bear River near Evanston } \\
\text { Bear River near Utah-Wyo. State line } \\
\text { Mill Creek at Utah-Wyo. State line } \\
\text { Sulphur Creek above reservoir, near Evanston } \\
\text { Whitney Canyon Creek near Evanston } \\
\text { Woodruff Creek near Woodruff, Utah } \\
\text { Twin Creek at Sage } \\
\text { Smiths Fork near Border } \\
\text { Thomas Fork near Geneva, Idaho } \\
\text { Salt Creek near Geneva, Idaho } \\
\text { Thomas Fork near Wyo.-Idaho State line } \\
\text { Montpelier Creek at weir, near Montpelier, Idaho } \\
\text { Bloomington Creek at Bloomington, Idaho } \\
\text { Georgetown Creek near Georgetown, Idaho } \\
\text { Weber River near Oakley, Utah } \\
\text { Pacific Creek at Moran } \\
\text { Blackrock Creek tributary near Moran } \\
\text { Buffalo Fork above Lava Creek, near Moran } \\
\text { Cache Creek near Jackson } \\
\text { Sour Moose Creek near Bondurant } \\
\text { Cliff Creek near Bondurant } \\
\text { Hoback River near Jackson } \\
\text { Fall Creek near Jackson } \\
\text { Cabin Creek near Jackson } \\
\text { Snake River above reservoir, near Alpine } \\
\text { Greys River above reservoir, near Alpine, Idaho } \\
\text { Fish Creek near Smoot } \\
\text { Crow Creek near Fairview } \\
\text { Strawberry Creek near Bedford } \\
\text { Bear Canyon near Freedom } \\
\text { McCoy Creek above reservoir, near Alpine, Idaho } \\
\text { Indian Creek above reservoir, near Alpine, Idaho } \\
\text { Elk Creek above reservoir, near Irwin, Idaho } \\
\text { Bear Creek above reservoir, near Irwin, Idaho } \\
\text { Targhee Creek near Macks Inn, Idaho } \\
\text { Mail Cabin Creek near Victor, Idaho } \\
\text { Moose Creek near Victor, Idaho }\end{array}$ \\
\hline
\end{tabular}


Table 7a.--Streamflow stations used in the analysis--Continued

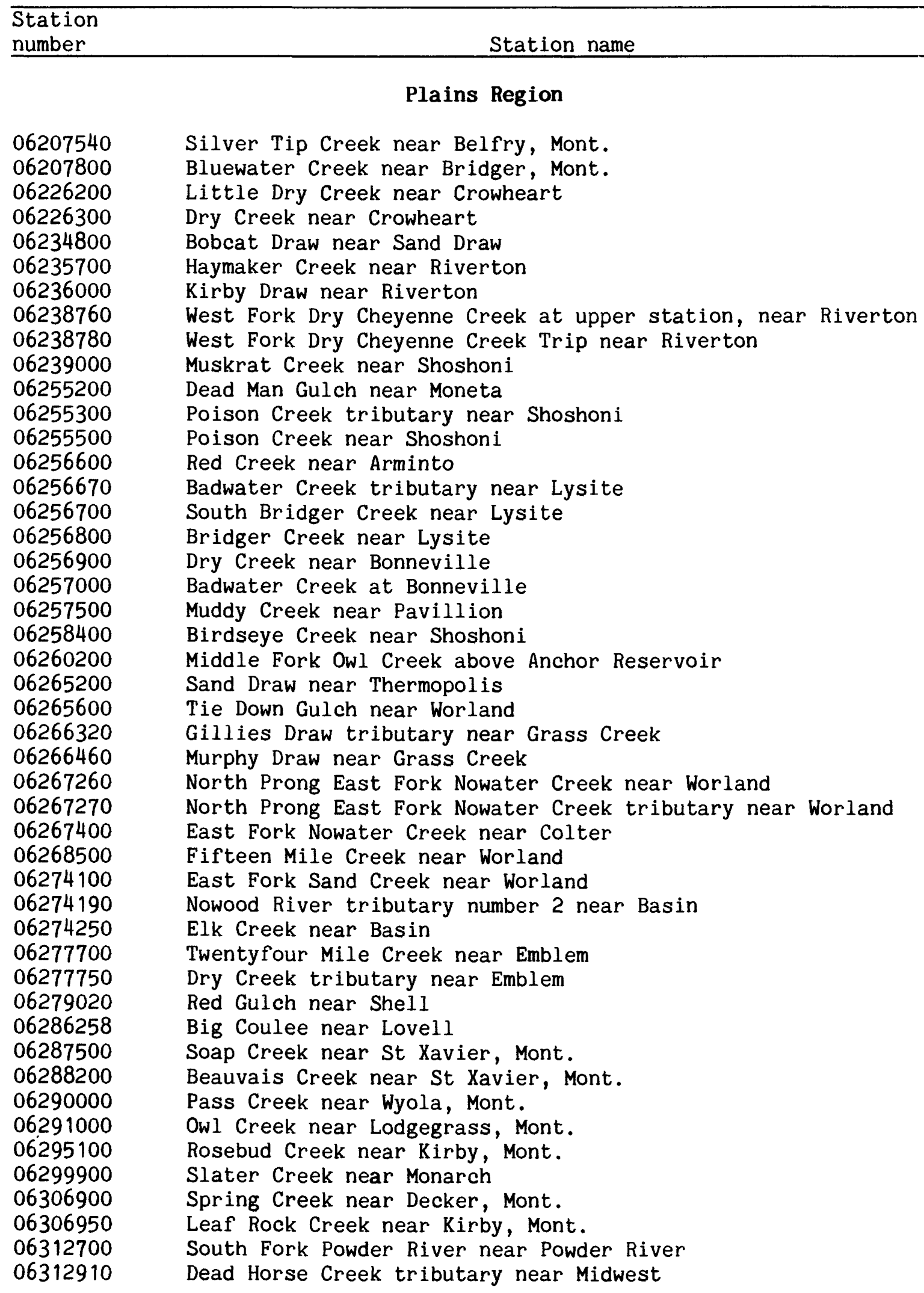

06207540

06207800

06226200

06226300

06234800

06235700

06236000

06238760

06238780

06239000

06255200

06255300

06255500

06256600

06256670

06256700

06256800

06256900

06257000

06257500

06258400

06260200

06265200

06265600

06266320

06266460

06267260

06267270

06267400

06268500

06274100

06274190

06274250

06277700

06277750

06279020

06286258

06287500

06288200

06290000

06291000

06295100

06299900

06306900

06306950

06312700

06312910

Silver Tip Creek near Belfry, Mont.

Bluewater Creek near Bridger, Mont.

Little Dry Creek near Crowheart

Dry Creek near Crowheart

Bobcat Draw near Sand Draw

Haymaker Creek near Riverton

Kirby Draw near Riverton

West Fork Dry Cheyenne Creek at upper station, near Riverton

West Fork Dry Cheyenne Creek Trip near Riverton

Muskrat Creek near Shoshoni

Dead Man Gulch near Moneta

Poison Creek tributary near Shoshoni

Poison Creek near Shoshoni

Red Creek near Arminto

Badwater Creek tributary near Lysite

South Bridger Creek near Lysite

Bridger Creek near Lysite

Dry Creek near Bonneville

Badwater Creek at Bonneville

Muddy Creek near Pavillion

Birdseye Creek near Shoshoni

Middle Fork Owl Creek above Anchor Reservoir

Sand Draw near Thermopolis

Tie Down Gulch near Worland

Gillies Draw tributary near Grass Creek

Murphy Draw near Grass Creek

North Prong East Fork Nowater Creek near Worland

North Prong East Fork Nowater Creek tributary near Worland

East Fork Nowater Creek near Colter

Fifteen Mile Creek near Worland

East Fork Sand Creek near Worland

Nowood River tributary number 2 near Basin

Elk Creek near Basin

Twentyfour Mile Creek near Emblem

Dry Creek tributary near Emblem

Red Gulch near Shell

Big Coulee near Lovell

Soap Creek near St Xavier, Mont.

Beauvais Creek near St Xavier, Mont.

Pass Creek near Wyola, Mont.

Owl Creek near Lodgegrass, Mont.

Rosebud Creek near Kirby, Mont.

Slater Creek near Monarch

Spring Creek near Decker, Mont.

Leaf Rock Creek near Kirby, Mont.

South Fork Powder River near Powder River

Dead Horse Creek tributary near Midwest 
Table 7a.--Streamflow stations used in the analysis--Continued

Station number

06312920

06313000

06313020

06313050

06313100

06313180

06313200

06313630

06313700

06316480

06316700

06317050

06319100

06324700

06324800

06324900

06324910

06324970

06325500

06334000

06334100

06334200

06334500

06358550

06358600

06358620

06378640

06379600

06382200

06386000

06386500

06387500

06388800

06394000

06396200

06396300

06396350

06399300

06399700

06400000

06400900

06404000

06406000

06422500

06425720

06426195

06426500

06432200

06432230

06434800

06436500
Station name

Dead Horse Creek tributary number 2 near Midwest

South Fork Powder River near Kaycee

Bobcat Creek near Edgerton

East Teapot Creek near Edgerton

Coal Draw near Midwest

Dugout Creek tributary near Midwest

Hay Draw near Midwest

Van Houten Draw near Buffalo

Dead Horse Creek near Buffalo

Headgate Draw at upper station, near Buffalo

Coal Draw near Buffalo

Rucker Draw near Spotted Horse

Bull Creek near Buffalo

Sand Creek near Broadus, Mont.

Little Powder River tributary near Gillette

Cedar Draw near Gillette

Cow Creek tributary near Weston

Little Powder River above Dry Creek, near Weston

Little Powder River near Broadus, Mont.

Little Missouri River near Alzada, Mont.

Wolf Creek near Hammond, Mont.

Willow Creek near Alzada, Mont.

Little Missouri River at Camp Crook, S. Dak.

Battle Creek tributary near Castle Rock, S. Dak.

South Fork Moreau River tributary near Redig, S. Dak.

Sand Creek tributary near Redig, S. Dak.

Lance Creek tributary near Lance Creek

Box Creek near Bill

Pritchard Draw near Lance Creek

Lance Creek at Spencer

Cheyenne River near Spencer

Turner Creek near Osage

Blacktail Creek tributary near Newcastle

Beaver Creek near Newcastle

Fiddle Creek near Edgemont, S. Dak.

Cottonwood Creek tributary near Edgemont, S. Dak.

Red Canyon Creek tributary near Pringle, S. Dak.

Hat Creek tributary near Ardmore, S. Dak.

Pine Creek near Ardmore, S. Dak.

Hat Creek near Edgemont, S. Dak.

Horsehead Creek tributary near Smithwick, S. Dak.

Battle Creek near Keystone, S. Dak.

Battle Creek at Hermosa, S. Dak.

Boxelder Creek near Nemo, S. Dak.

Belle Fourche River below Rattlesnake Creek, near Piney

Donkey Creek tributary above reservoir, near Gillette

Belle Fourche River below Moorcroft

Polo Creek near Whitewood, S. Dak.

Miller Creek near Whitewood, S. Dak.

Owl Creek tributary near Belle Fourche, S. Dak.

Horse Creek near Newell, S. Dak. 
Table 7a.--Streamflow stations used in the analysis--Continued

\begin{tabular}{ll}
\hline $\begin{array}{l}\text { Station } \\
\text { number }\end{array}$ & \multicolumn{1}{c}{ Station name } \\
\hline 06436700 & Indian Creek near Arpan, S. Dak. \\
06436770 & Dry Creek tributary near Newell, S. Dak. \\
06437100 & Boulder Creek near Deadwood, S. Dak. \\
06443200 & White River tributary near Glen, Nebr. \\
06443300 & Deep Creek near Glen, Nebr. \\
06443700 & Soldiers Creek near Crawford, Nebr. \\
06444000 & White River at Crawford, Nebr. \\
06454000 & Niobrara River at Wyoming-Nebraska State line \\
06456200 & Pebble Creek near Esther, Nebr. \\
06644200 & Clarks Gulch near Natrona \\
06644840 & McKenzie Draw tributary near Casper \\
06646700 & East Fork Dry Creek tributary near Glenrock \\
06648720 & Frank Draw tributary near Orpha \\
06648780 & Sage Creek tributary near Orpha \\
06649900 & North Platte River tributary near Douglas \\
06651800 & Sand Creek near Orin \\
06652400 & Watkins Draw near Lost Springs \\
06668040 & Rabbit Creek near Wheatland \\
06671000 & Rawhide Creek near Lingle \\
06675300 & Horse Creek tributary near Little Bear \\
06677500 & Horse Creek near Lyman, Nebr. \\
06679000 & Dry Spottedtail Creek at Mitchell, Nebr. \\
06761900 & Lodgepole Creek tributary near Pine Bluffs \\
06762500 & Lodgepole Creek at Bushnell, Nebr. \\
06762600 & Lodgepole Creek tributary number 2 near Albin \\
&
\end{tabular}

\section{High Desert Region}

06218700

06229700

06233360

06234700

06629150

06629200

06629800

06630200

06631150

06634600

06634910

06634950

06634990

06636500

06638350

06641400

06642700

06642730

06642760

06643300

09204700
Wagon Gulch near Dubois

Norkok Meadows Creek near Fort Washakie

Monument Draw at lower station, near Hudson

South Fork Hall Creek near Lander

Coal Bank Draw tributary near Walcott

Coal Bank Draw tributary number 2 near Walcott

Coal Creek near Rawlins

Big Ditch tributary near Hanna

Third Sand Creek near Medicine Bow

Little Medicine Bow River near Medicine Bow

Medicine Bow River tributary near Hanna

Willow Springs Draw tributary near Hanna

Hanna Draw near Hanna

Sage Creek above Pathfinder Reservoir

Coal Creek near Muddy Gap

Bear Springs Creek near Alcova

Lawn Creek near Alcova

Stinking Creek tributary near Alcova

Stinking Creek near Alcova

Coal Creek near Goose Egg

Sand Springs Draw tributary near Boulder 
Table 7a.--Streamflow stations used in the analysis--Continued

\begin{tabular}{ll}
\hline Station & \\
number & \multicolumn{1}{c}{ Station name } \\
\hline 09207650 & Dry Basin Creek near Big Piney \\
09215000 & Pacific Creek near Farson \\
09216290 & East Otterson Wash near Green River \\
09216350 & Skunk Canyon Creek near Green River \\
09216400 & Greasewood Canyon near Green River \\
09216537 & Delaney Draw near Red Desert \\
09216545 & Bitter Creek near Bitter Creek \\
09216550 & Deadman Wash near Point of Rocks \\
09216560 & Bitter Creek near Point of Rocks \\
09216562 & Bitter Creek above Salt Wells Creek, near Salt Wells \\
09216565 & Salt Wells Creek near South Baxter \\
09216580 & Big Flat Draw near Rock Springs \\
09216600 & Cutthroat Draw near Rock Springs \\
09216695 & No Name Creek near Rock Springs \\
09216700 & Salt Wells Creek near Rock Springs \\
09216750 & Salt Wells Creek near Salt Wells \\
09221680 & Mud Spring Hollow near Church Butte, near Lyman \\
09222400 & Muddy Creek near Hampton \\
09224600 & Blacks Fork tributary near Granger \\
09224800 & Meadow Springs Wash tributary near Green River \\
09224810 & Blacks Fork tributary number 2 near Green River \\
09224820 & Blacks Fork tributary number 3 near Green River \\
09224840 & Blacks Fork tributary number 4 near Green River \\
09224980 & Summers Dry Creek near Green River \\
09225200 & Squaw Hollow near Burntfork \\
09225300 & Green River tributary number 2 near Burntfork \\
09229450 & Henrys Fork tributary near Manila, Utah \\
09258200 & Dry Cow Creek near Baggs \\
09258900 & Muddy Creek above Baggs \\
\hline & \\
\hline &
\end{tabular}




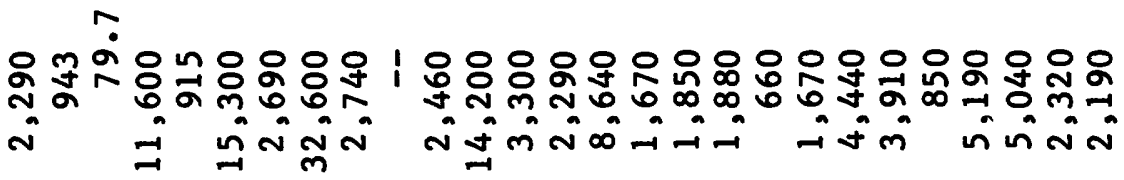

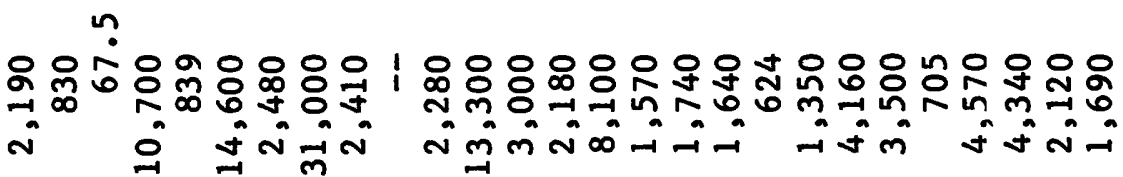

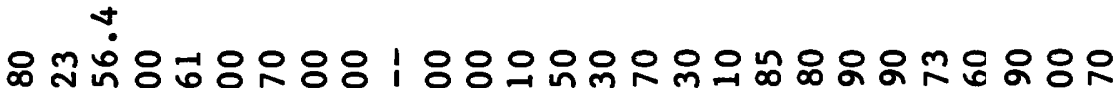
O세

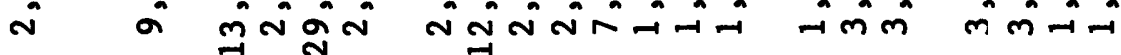

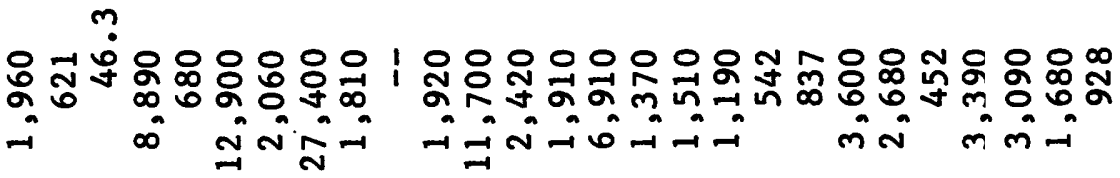

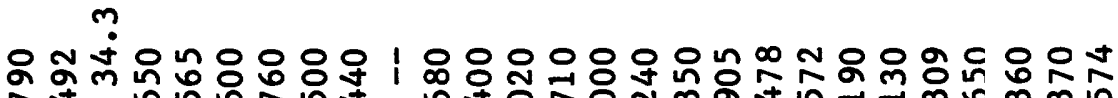
t.

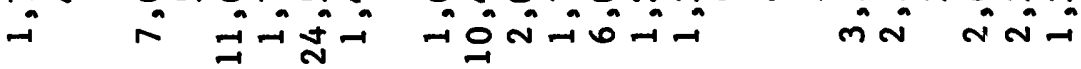

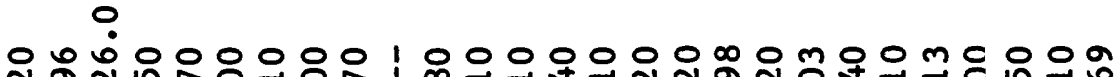

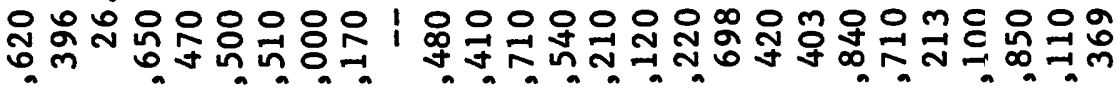

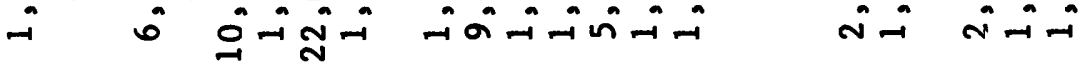

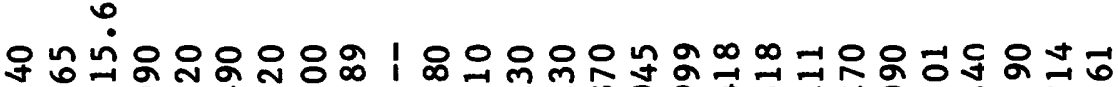

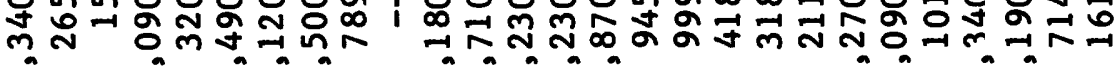

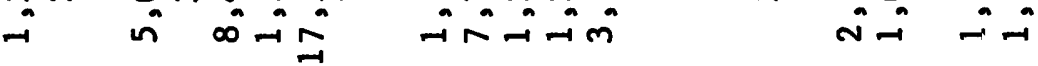

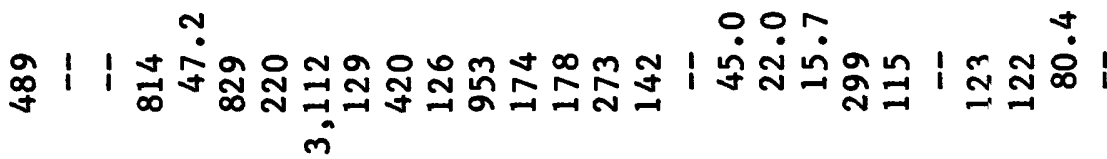

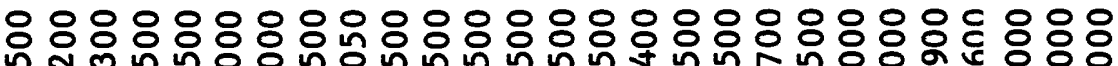
ก้ำ

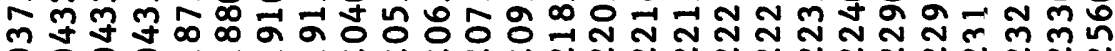

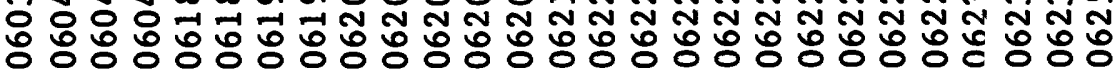




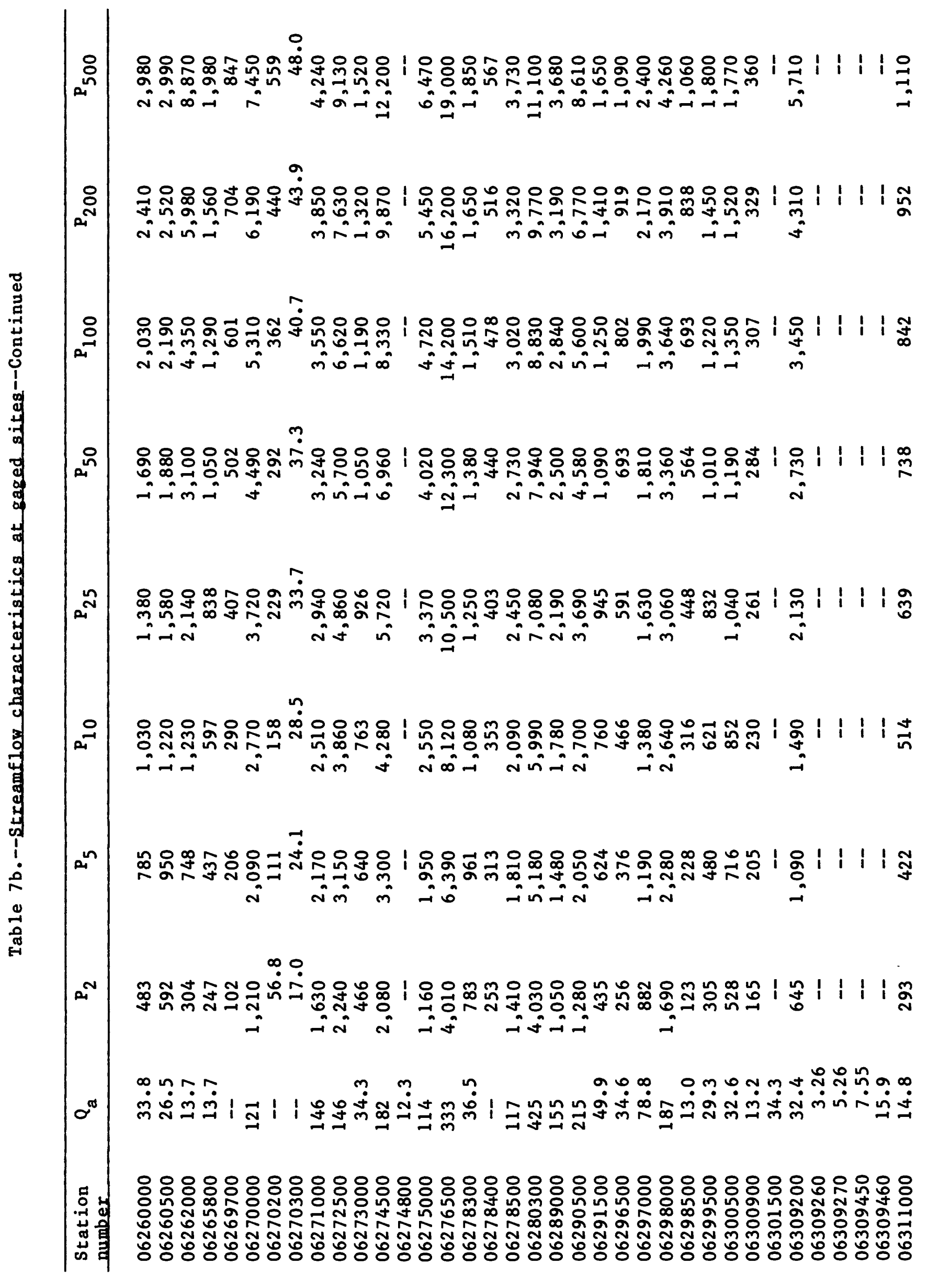




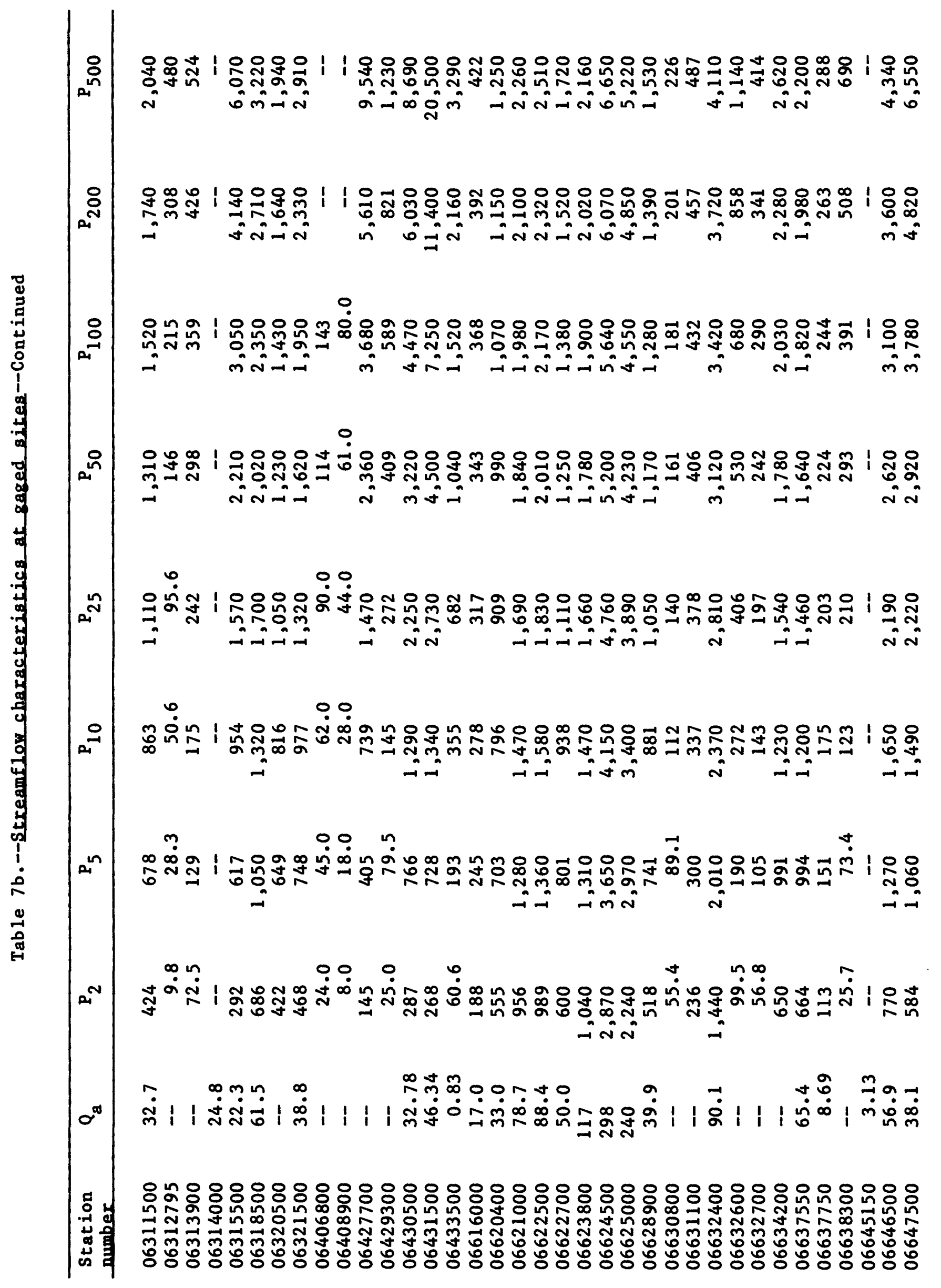




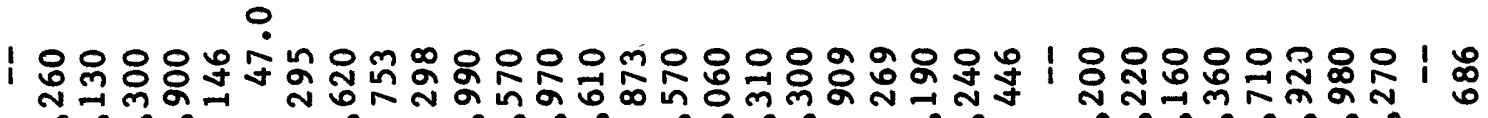

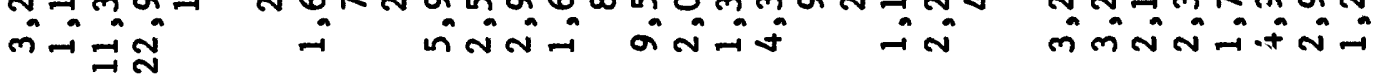

0

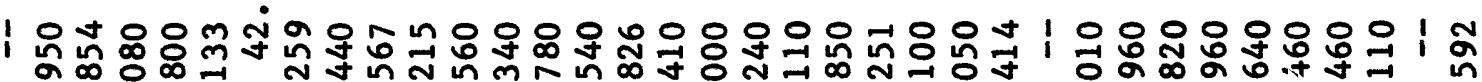
n $\infty$ ñ

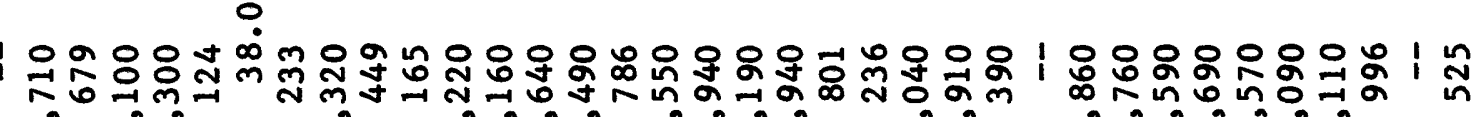
i ०0

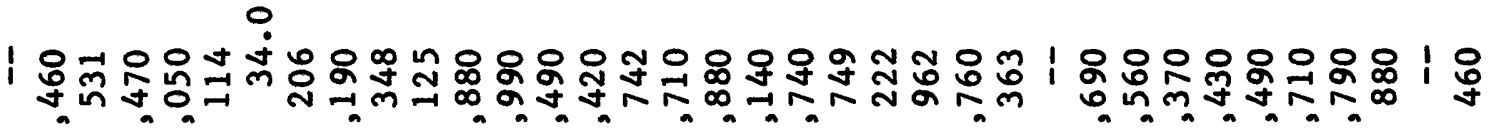

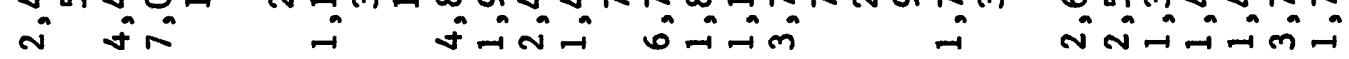

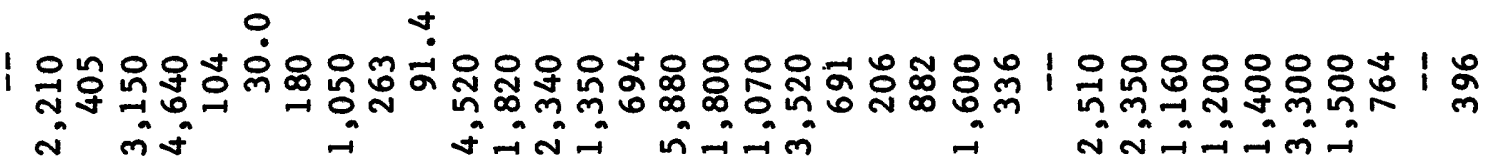

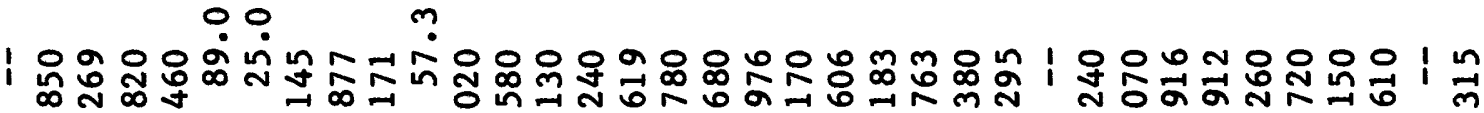

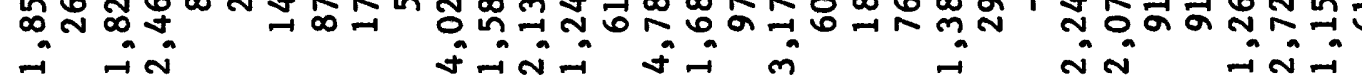

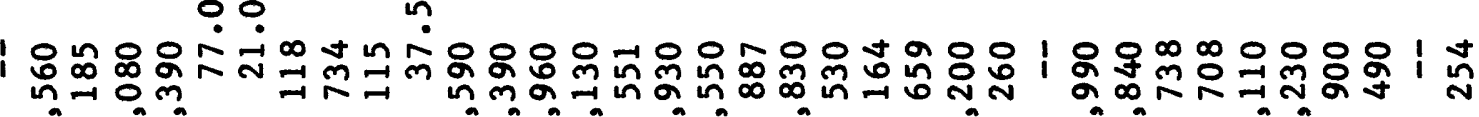
$-\rightarrow-1$

ma

(n)

-in

|을

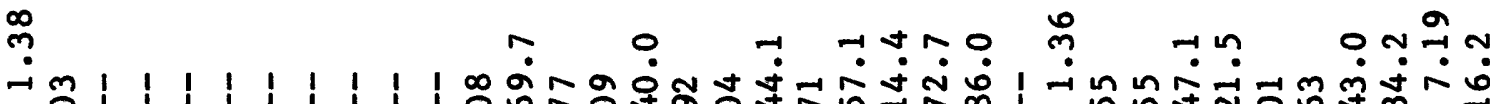
인 1 1 1 | 1 |

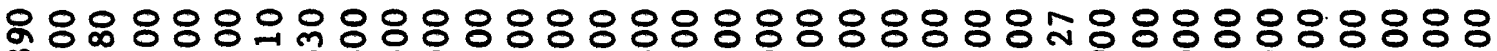

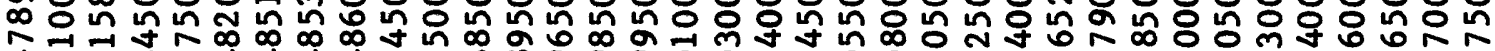
₹-1

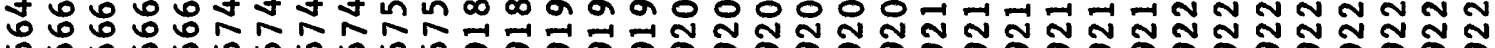

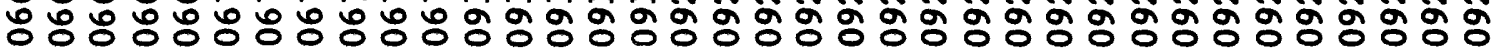




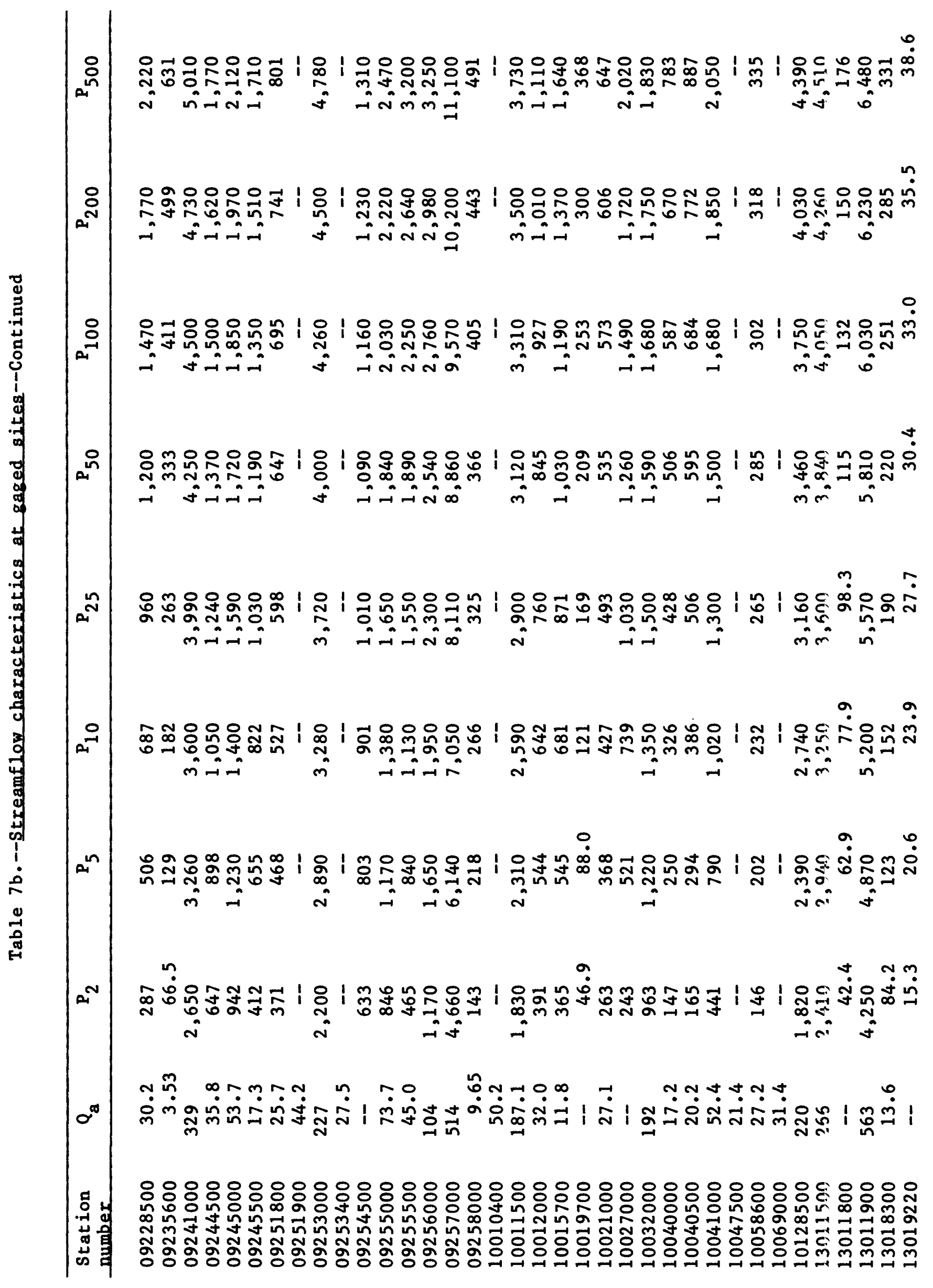




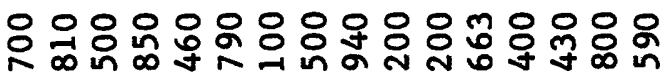

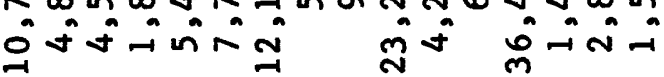

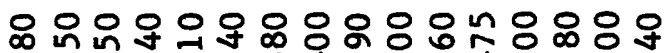
Nat

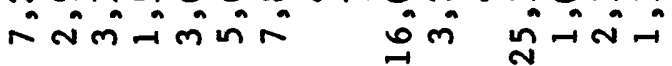

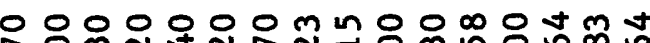

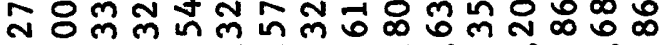

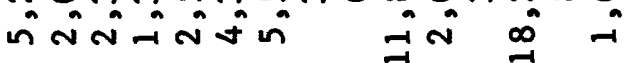

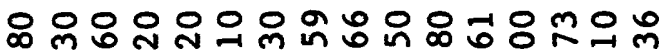

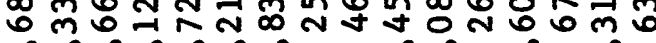

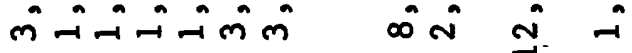

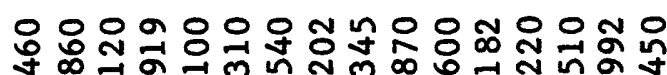

$\therefore=$ -

音

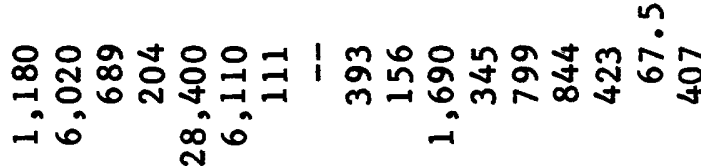

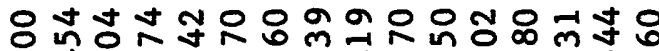

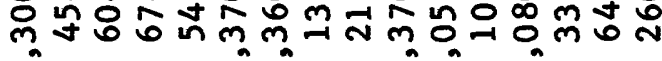

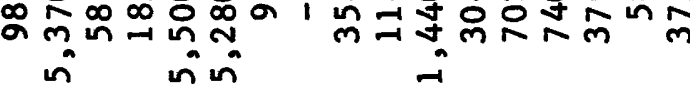

$\rightarrow \quad-i$ in

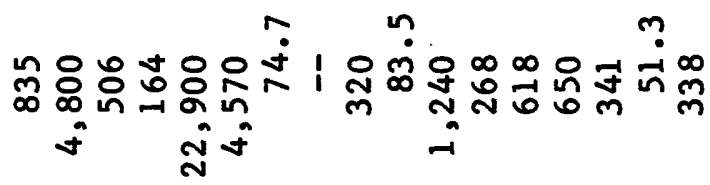

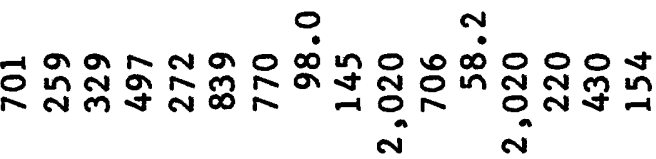

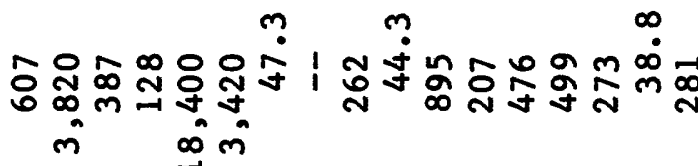

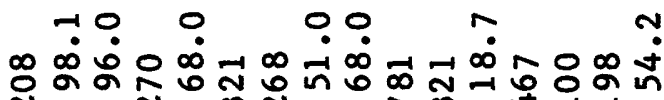

20

$\rightarrow$

|

$|\stackrel{\infty}{\infty}| 1|1| \begin{aligned} & 0 \\ & 0\end{aligned}$

m $\boldsymbol{m}$

m

০০০০০০০০০০০০০০০০০০০ I

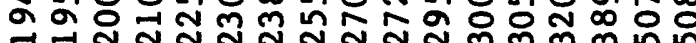
ส

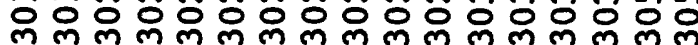

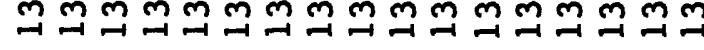

엉ㅇㅇㅇㅇㅇㅇㅇㅇㅇㅇㅇㅇㅇㅇㅇㅇㅇㅇㅇㅇㅇㅇㅇ non 人ิ กิ ㅇㅇㅇㅇㅇㅇㅇㅇㅇㅇㅇㅇㅇㅇㅇㅇㅇㅇㅇㅇㅇㅇㅇㅇ 


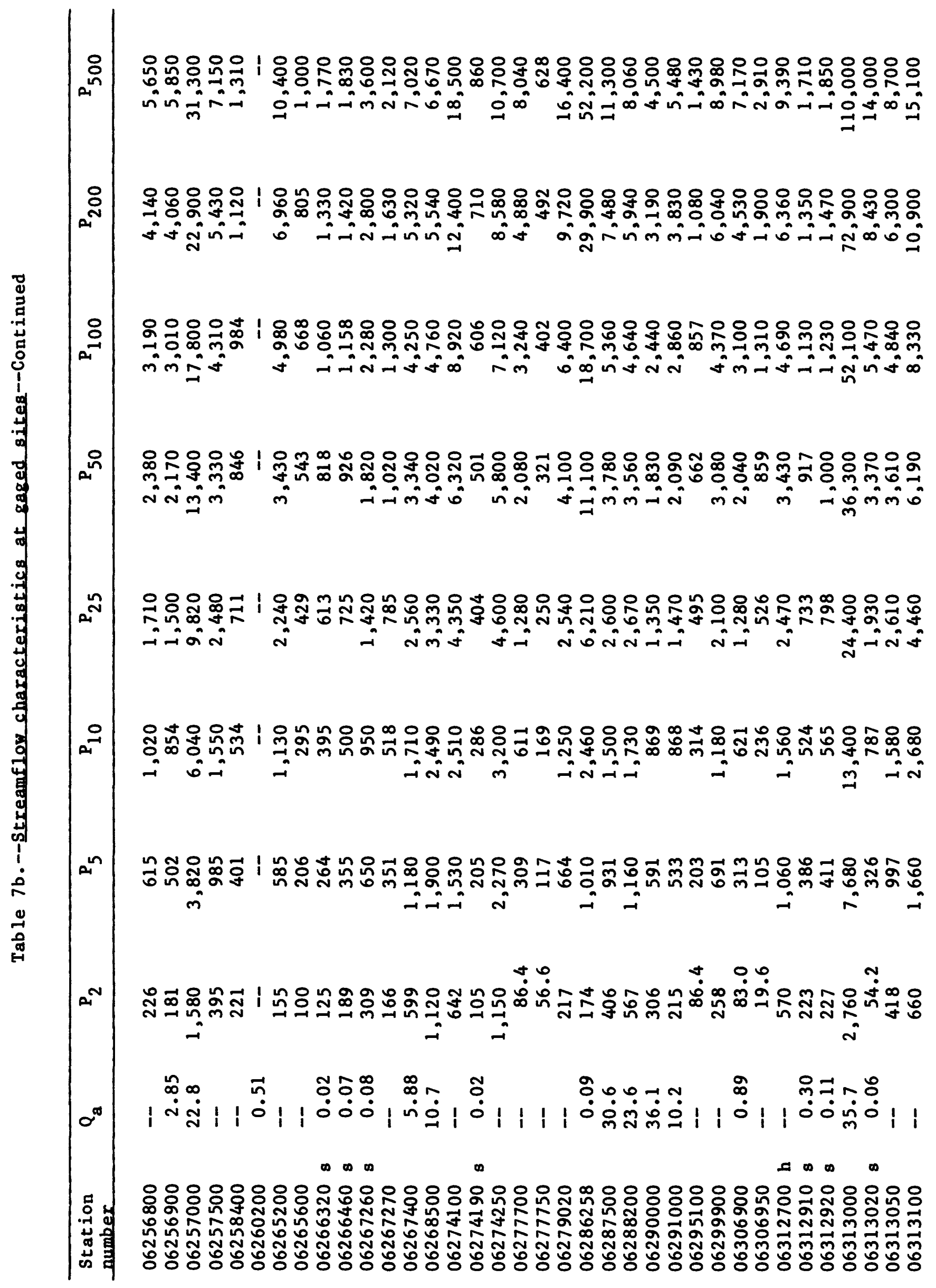




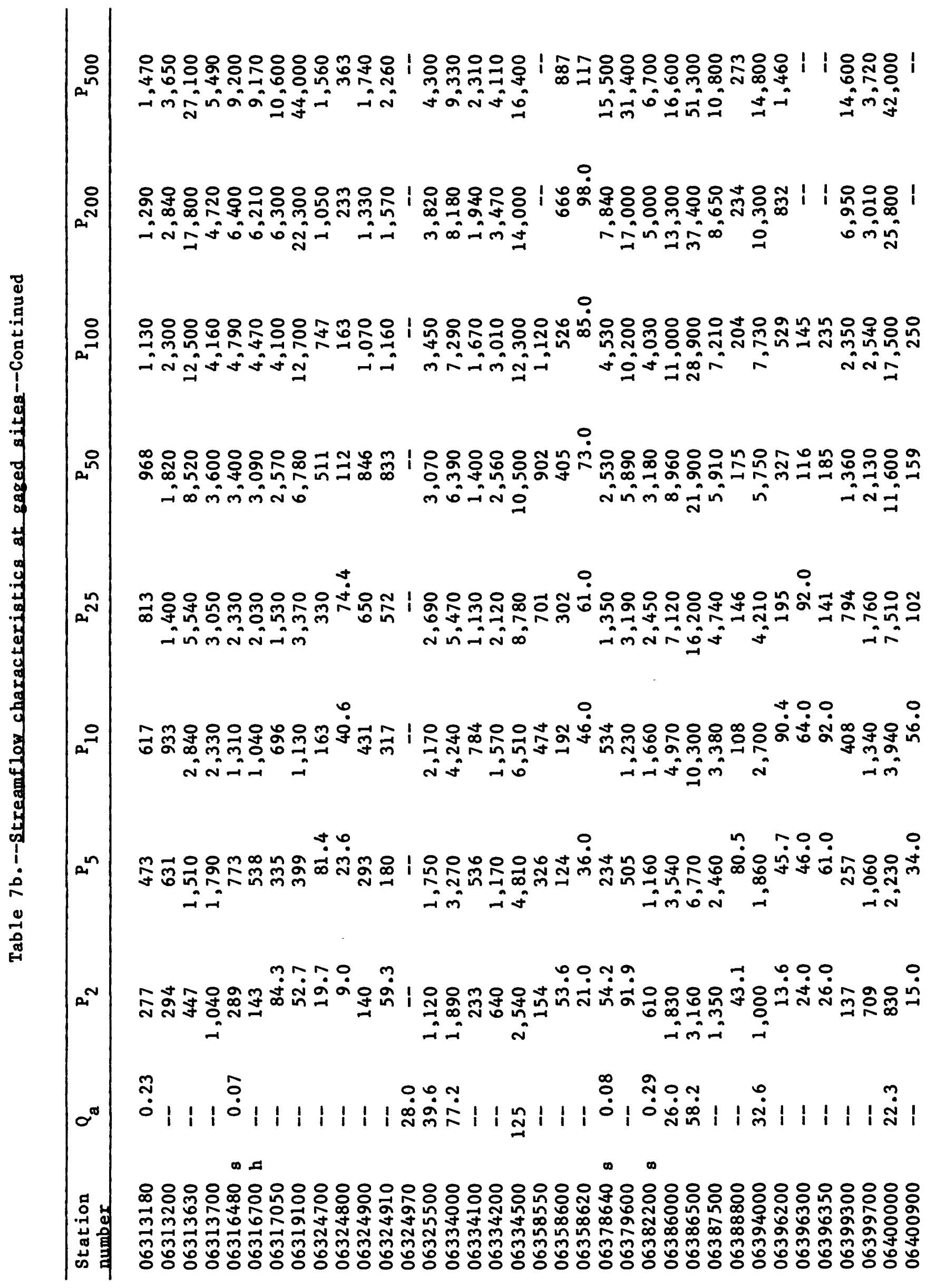




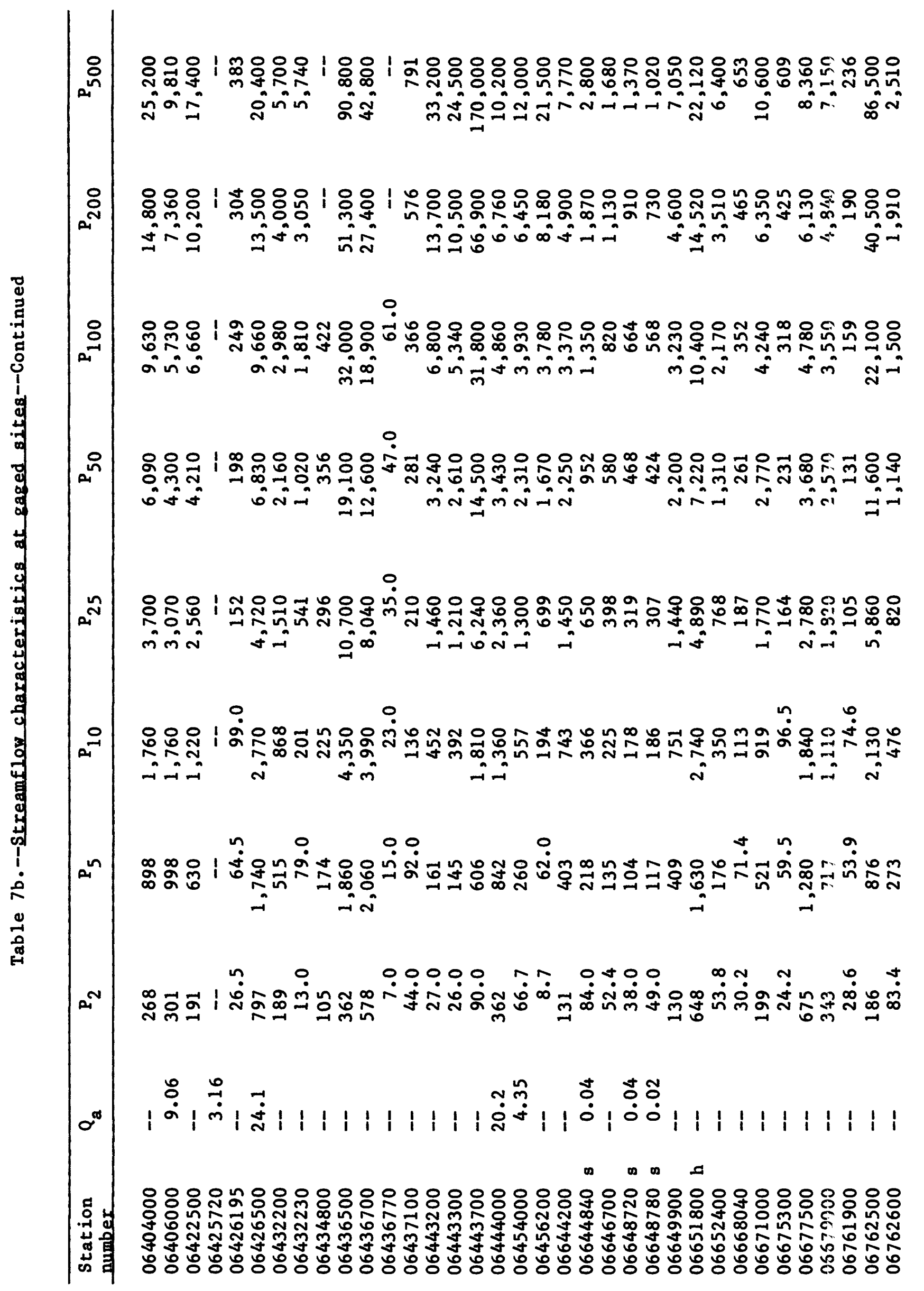




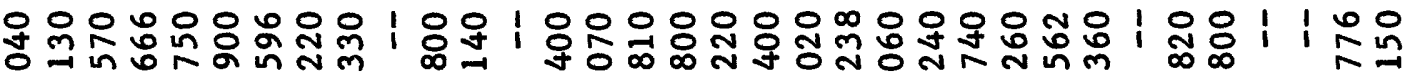
an

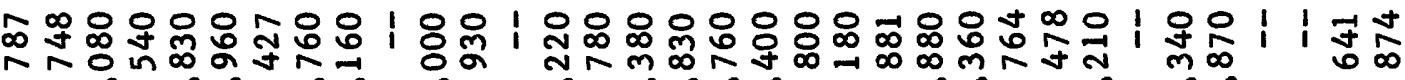
i i- $-m$ in min

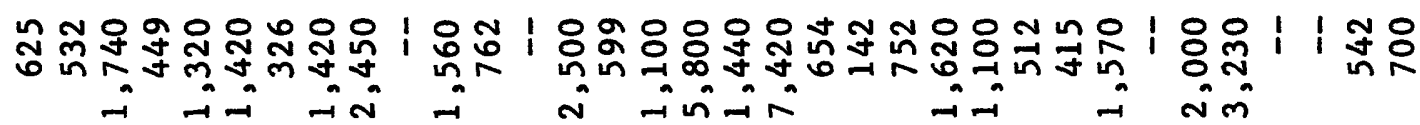

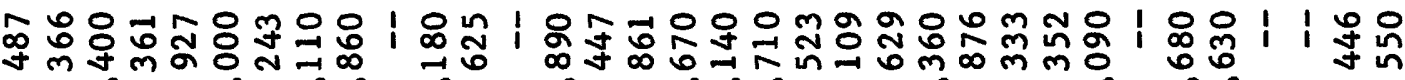
$\rightarrow \quad-i \rightarrow-i$ - $\rightarrow$ in

Sis

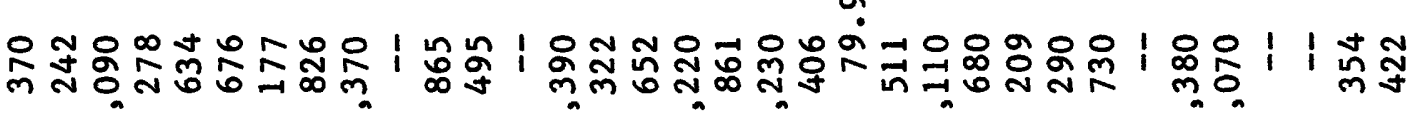

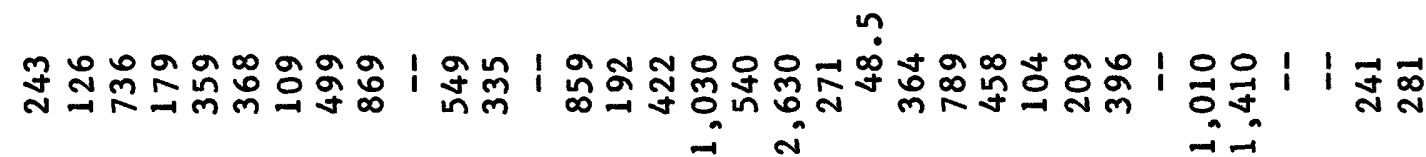

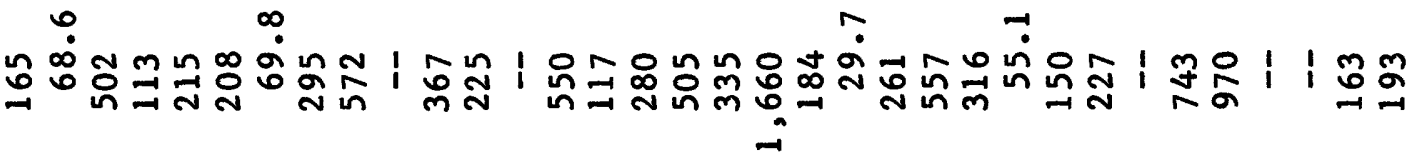
กษ

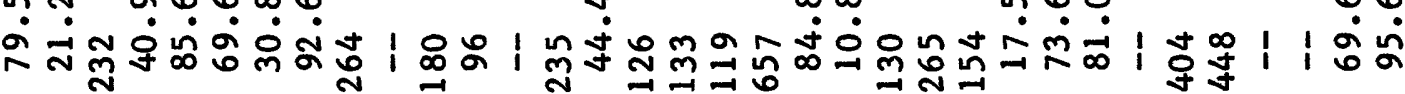

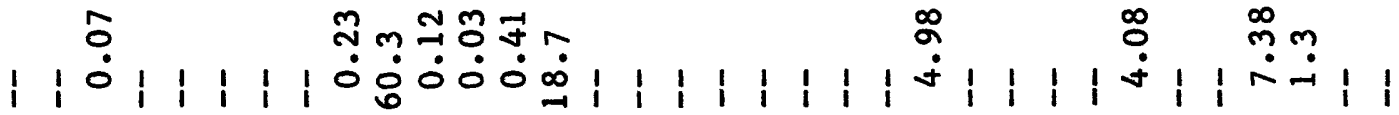

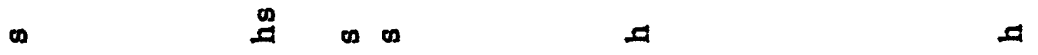

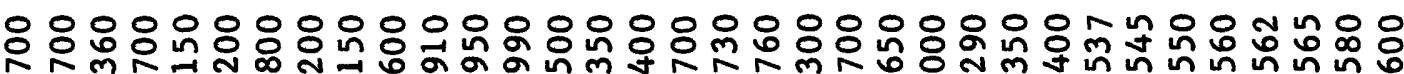
क

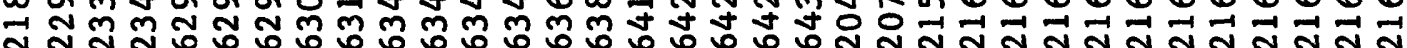
ㅇㅇㅇㅇㅇㅇㅇㅇㅇㅇㅇㅇㅇㅇㅇㅇㅇㅇㅇㅇㅇㅇㅇㅇㅇㅇㅇㅇㅇㅇㅇㅇㅇㅇㅇㅇㅇㅇㅇㅇㅇㅇ 


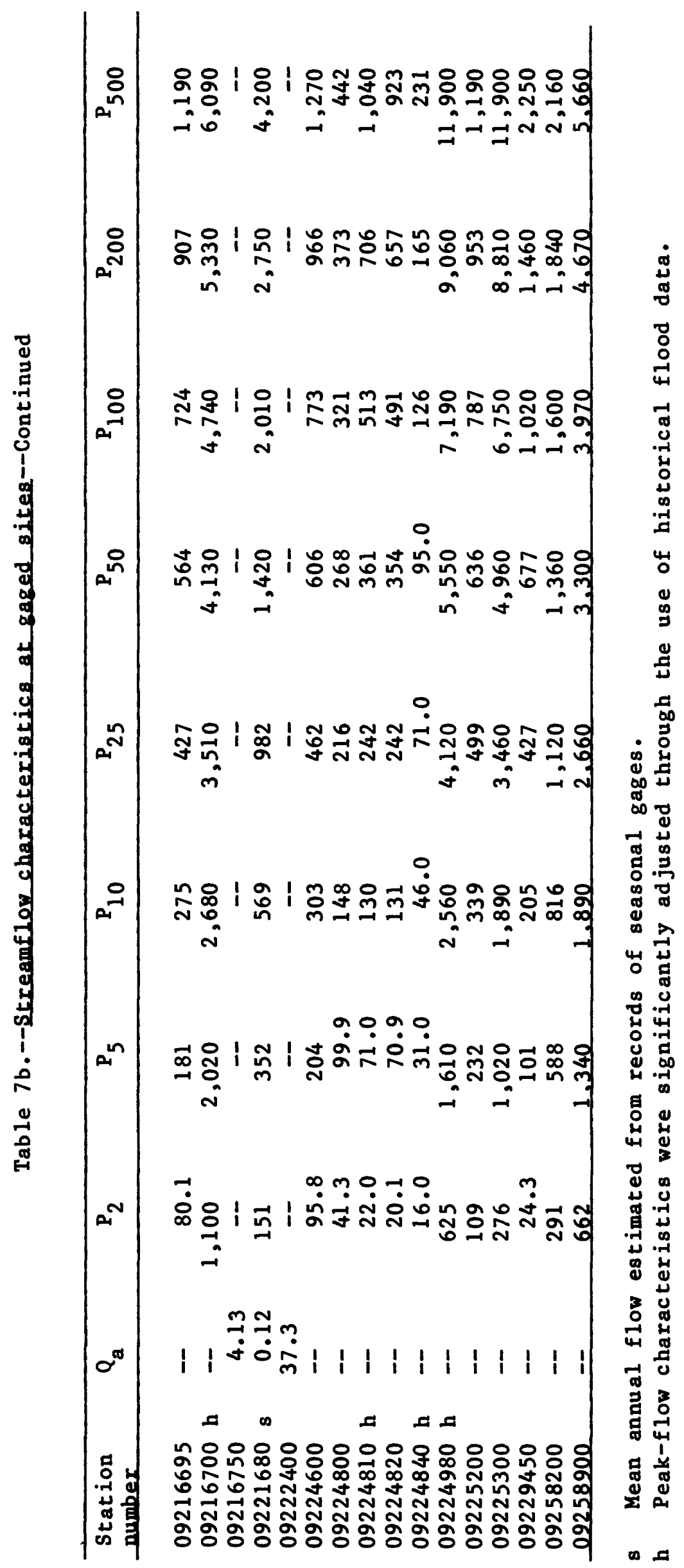


Table 7c.--Basin characteristics and channel width

[A = contributing drainage area, in square miles; $S_{B}=$ basin slope, in feet per mile; ELEV = mean basin elevation, in feet; $P R=$ average annual precipitation, in inches; WIDTH = channel width, in feet; $G_{f}=$ geographic factor; --, data either not available or not applicable]

\begin{tabular}{lllllll}
\hline $\begin{array}{l}\text { Station } \\
\text { number }\end{array}$ & $A$ & $S_{B}$ & ELEV & PR & WIDTH & $\mathrm{G}_{\mathrm{f}}$ \\
\hline
\end{tabular}

Mountainous Regions

\begin{tabular}{|c|c|c|c|c|c|c|}
\hline 06037500 & 420 & -- & 7,920 & 20 & 92 & -- \\
\hline 06043200 & 40.4 & -- & 7,440 & 35 & - & -- \\
\hline 06043300 & 2.48 & -- & 7,120 & 30 & -- & - \\
\hline 06043500 & 825 & -- & 7,960 & 37 & -- & -- \\
\hline 06187500 & 50.4 & -- & 8,340 & 28 & -- & -- \\
\hline 06188000 & 660 & -- & 7,400 & 34 & 128 & -- \\
\hline 06191000 & 202 & -- & 7,940 & 30 & 56 & -- \\
\hline 06191500 & 2,623 & -- & 8,440 & 33 & $=$ & -- \\
\hline 06204050 & 52.1 & -- & 9,560 & 55 & -- & - \\
\hline 06205500 & 194 & -- & 8,760 & 25 & -- & -- \\
\hline 06206500 & 135 & -- & 8,500 & 25 & 53 & -- \\
\hline 06207500 & 1,154 & -- & 7,430 & 17 & 180 & $=-$ \\
\hline 06209500 & 124 & -- & 9,540 & 40 & -- & $=-$ \\
\hline 06218500 & 232 & -- & 8,920 & 20 & 54 & - \\
\hline 06220500 & 427 & -- & 9,140 & 20 & - & - \\
\hline 06221400 & 88.2 & -- & 10,500 & 25 & 74 & - \\
\hline 06221500 & 100 & -- & 10,200 & 22 & - & - \\
\hline 06222500 & 53.2 & -- & 10,100 & 22 & -- & - \\
\hline 06222700 & 30.2 & -- & 9,950 & 18 & 24 & - \\
\hline 06223500 & 55.4 & -- & 8,720 & 17 & -- & - \\
\hline 06224000 & 187 & -- & 10,300 & 25 & -- & 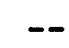 \\
\hline 06229000 & 127 & -- & 9,620 & 21 & -- & - \\
\hline 06229900 & 16.1 & 794 & 9,620 & 15 & -- & $=$ \\
\hline 06231600 & 87.5 & - & 9,920 & 20 & -- & $=-$ \\
\hline 06232000 & 98.4 & -- & 9,890 & 22 & -- & 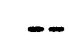 \\
\hline 06233000 & 125 & -- & 8,020 & 18 & -- & -- \\
\hline 06256000 & 131 & 1,480 & 7,320 & 14 & 24 & 8 \\
\hline 06260000 & 87.0 & -- & 9,530 & 21 & 37 & - \\
\hline 06260500 & 144 & -- & 8,750 & 19 & - & - \\
\hline 06262000 & 54.8 & -- & 8,840 & 19 & 44 & - \\
\hline 06265800 & 95.0 & 1,900 & 7,100 & 16 & 17 & - \\
\hline 06269700 & 57.9 & 1,260 & 5,800 & 13 & 10 & - \\
\hline 06270000 & 803 & - & 6,050 & 14 & 52 & -7 \\
\hline 06270200 & 2.54 & -- & 9,510 & 18 & - & 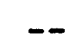 \\
\hline 06270300 & 0.52 & -- & 9,600 & 20 & 2 & . \\
\hline 06271000 & 247 & -- & 8,190 & 17 & 50 & \\
\hline 06272500 & 164 & -- & 9,120 & 16 & 71 & 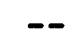 \\
\hline 06273000 & 86.8 & - & 8,070 & 17 & 30 & \\
\hline 06274500 & 282 & -- & 9,740 & 22 & 80 & \\
\hline 06274800 & 7.66 & -- & 10,830 & 24 & -- & \\
\hline 06275000 & 194 & -- & 9,100 & 20 & 50 & \\
\hline 06276500 & 681 & -- & 7,070 & 19 & -- & \\
\hline 06278300 & 23.1 & - & 10,030 & 18 & 32 & \\
\hline
\end{tabular}


Table 7c.--Basin characteristics and channel width--Continued

\begin{tabular}{|c|c|c|c|c|c|c|}
\hline $\begin{array}{l}\text { Station } \\
\text { number }\end{array}$ & A & ${ }^{S}{ }_{B}$ & ELEV & PR & WIDTH & $G_{f}$ \\
\hline 06278400 & 11.1 & -- & 8,950 & 16 & 24 & -- \\
\hline 06278500 & 145 & -- & 8,810 & 15 & 60 & -- \\
\hline 06280300 & 297 & -- & 9,250 & 25 & 107 & -- \\
\hline 06289000 & 193 & -- & 7,830 & 20 & 49 & -- \\
\hline 06290500 & 428 & - & 6,140 & 20 & -- & -- \\
\hline 06291500 & 80.7 & -- & 6,360 & 22 & -- & -- \\
\hline 06296500 & 32.4 & -- & 9,270 & 17 & 26 & -- \\
\hline 06297000 & 85.0 & - & 8,920 & 20 & 47 & -- \\
\hline 06298000 & 204 & -- & 8,330 & 19 & 54 & -- \\
\hline 06298500 & 25.1 & - & 7,560 & 20 & 16 & -- \\
\hline 06299500 & 37.8 & - & 7,700 & 20 & 30 & -- \\
\hline 06300500 & 20.1 & -- & 9,560 & 23 & 34 & -- \\
\hline 06300900 & 9.29 & -- & 9,990 & 24 & -- & -- \\
\hline 06301500 & 24.4 & -- & 9,560 & 20 & -- & -- \\
\hline 06309200 & 45.2 & -- & 8,000 & 16 & -- & -- \\
\hline 06309260 & 8.80 & -- & 8,370 & 15 & -- & -- \\
\hline 06309270 & 8.10 & - & 8,750 & 15 & -- & -- \\
\hline 06309450 & 10.9 & -- & 7,620 & 17 & -- & -- \\
\hline 06309460 & 24.2 & -- & 7,180 & 17 & -- & -- \\
\hline 06311000 & 24.5 & -- & 8,990 & 20 & 25 & -- \\
\hline 06311500 & 106 & -- & 7,990 & 17 & 23 & -- \\
\hline 06312795 & 5.53 & 1,161 & 8,010 & 13 & 7 & -- \\
\hline 06313900 & 5.08 & - & 8,400 & 13 & -- & -- \\
\hline 06314000 & 44.9 & -- & 8,440 & 15 & -- & -- \\
\hline 06315500 & 82.7 & -- & 8,010 & 16 & 35 & -- \\
\hline 06318500 & 120 & -- & 8,860 & 17 & 62 & -- \\
\hline 06320500 & 33.6 & -- & 10,100 & 24 & -- & -- \\
\hline 06321500 & 36.8 & -- & 7,920 & 23 & 46 & -- \\
\hline 06406800 & 8.17 & 1,470 & 6,100 & 22 & -- & -- \\
\hline 06408900 & 4.88 & 1,010 & 6,600 & 21 & -- & -- \\
\hline 06427700 & 96.5 & 760 & 5,450 & 17 & 15 & -- \\
\hline 06429300 & 8.42 & 1,540 & 5,690 & 18 & -- & -- \\
\hline 06430500 & 471 & -- & 5,000 & 20 & 30 & -- \\
\hline 06431500 & 168 & -- & 5,700 & 22 & -- & -- \\
\hline 06433500 & 121 & 653 & 3,700 & 19 & -- & -- \\
\hline 06616000 & 21.2 & -- & 9,800 & 26 & -- & -- \\
\hline 06620400 & 22.1 & -- & 9,740 & 26 & -- & -- \\
\hline 06621000 & 120 & -- & 9,190 & 30 & 44 & -- \\
\hline 06622500 & 59.6 & -- & 9,460 & 30 & 43 & -- \\
\hline 06622700 & 37.4 & - & 9,480 & 28 & 40 & -- \\
\hline 06623800 & 72.7 & -- & 9,700 & 26 & -- & -- \\
\hline 06624500 & 211 & -- & 8,950 & 20 & -- & -- \\
\hline 06625000 & 265 & -- & 8,900 & 17 & 85 & -- \\
\hline 06628900 & 91.5 & -- & 8,560 & 18 & 30 & -- \\
\hline 06630800 & 8.93 & 659 & 7,800 & 12 & 8 & -- \\
\hline 06631100 & 25.6 & -- & 8,500 & 13 & 20 & -- \\
\hline 06632400 & 62.9 & -- & 9,680 & 22 & 62 & -- \\
\hline 06632600 & 6.31 & -- & 8,980 & 14 & 13 & -- \\
\hline 06632700 & 3.59 & -- & 8,660 & 14 & -- & -- \\
\hline 06634200 & 61.0 & -- & 8,000 & 14 & 44 & -- \\
\hline
\end{tabular}


Table 7c.--Basin characteristics and channel width--Continued

\begin{tabular}{|c|c|c|c|c|c|c|}
\hline $\begin{array}{l}\text { Station } \\
\text { number }\end{array}$ & A & $S_{B}$ & ELEV & PR & WIDTH & $G_{f}$ \\
\hline 06637550 & 177 & -- & 8,660 & 18 & 33 & -- \\
\hline 06637750 & 9.20 & -- & 8,990 & 17 & -- & -- \\
\hline 06638300 & 11.6 & 554 & 7,010 & 12 & 4.8 & -- \\
\hline 06645150 & 9.91 & - & 7,210 & 15 & -- & -- \\
\hline 06646500 & 212 & -- & 6,790 & 15 & 58 & -- \\
\hline 06647500 & 63.0 & -- & 7,960 & 16 & 33 & -- \\
\hline 06647890 & 7.18 & -- & 6,320 & 15 & -- & -- \\
\hline 06661000 & 157 & -- & 9,110 & 20 & 58 & -- \\
\hline 06661580 & 11.2 & 264 & 8,790 & 13 & 12 & -- \\
\hline 06664500 & 225 & -- & 6,700 & 14 & 38 & -- \\
\hline 06667500 & 370 & -- & 7,200 & 14 & 38 & -- \\
\hline 06748200 & 3.64 & -- & 11,100 & 28 & -- & -- \\
\hline 06748510 & 0.89 & -- & 10,900 & 25 & -- & -- \\
\hline 06748530 & 12.0 & -- & 9,700 & 23 & -- & -- \\
\hline 06748600 & 90.3 & -- & 9,900 & 22 & -- & -- \\
\hline 06754500 & 25.8 & -- & 8,140 & 16 & 10 & -- \\
\hline 06755000 & 13.9 & -- & 7,810 & 16 & 7.3 & -- \\
\hline 09188500 & 468 & -- & 9,320 & 22 & 110 & -- \\
\hline 09189500 & 43.0 & -- & 8,880 & 20 & 44 & -- \\
\hline 09196500 & 75.8 & -- & 10,200 & 23 & 67 & -- \\
\hline 09198500 & 87.5 & -- & 10,000 & 22 & 62 & -- \\
\hline 09199500 & 37.2 & -- & 9,460 & 20 & 34 & -- \\
\hline 09201000 & 552 & -- & 8,640 & 20 & 100 & -- \\
\hline 09203000 & 79.2 & -- & 9,580 & 22 & 56 & -- \\
\hline 09204000 & 45.4 & -- & 9,750 & 20 & 25 & -- \\
\hline 09204500 & 348 & -- & 8,380 & 18 & -- & -- \\
\hline 09205500 & 58.0 & -- & 8,920 & 18 & -- & -- \\
\hline 09208000 & 6.30 & -- & 8,970 & 25 & 14 & -- \\
\hline 09210500 & 152 & -- & 8,160 & 18 & 32 & -- \\
\hline 09212500 & 94.0 & -- & 9,250 & 20 & 49 & -- \\
\hline 09214000 & 20.9 & -- & 9,820 & 19 & 23 & -- \\
\hline 09216527 & 53.3 & -- & 7,480 & 13 & -- & -- \\
\hline 09217900 & 130 & -- & 10,640 & 20 & -- & -- \\
\hline 09218500 & 152 & -- & 10,270 & 19 & 70 & -- \\
\hline 09220000 & 53.0 & - & 10,250 & 20 & 35 & -- \\
\hline 09220500 & 37.2 & -- & 9,790 & 20 & 28 & -- \\
\hline 09223000 & 128 & -- & 8,380 & 25 & 44 & -- \\
\hline 09224000 & 386 & -- & 7,910 & 18 & -- & -- \\
\hline 09226000 & 56.0 & -- & 10,270 & 23 & 40 & -- \\
\hline 09226500 & 28.0 & -- & 10,480 & 31 & 24 & - \\
\hline 09227000 & 8.20 & -- & 10,680 & 22 & -- & -- \\
\hline 09227500 & 23.0 & -- & 10,490 & 32 & 19 & -- \\
\hline 09228500 & 52.8 & -- & 10,300 & 29 & -- & -- \\
\hline 09235600 & 25.0 & -- & 8,170 & 20 & -- & -- \\
\hline 09241000 & 206 & -- & 9,000 & 37 & -- & -- \\
\hline 09244500 & 45.4 & -- & 8,600 & 27 & -- & -- \\
\hline 09245000 & 64.2 & - & 8,400 & 26 & -- & -- \\
\hline 09245500 & 21.0 & - & 8,600 & 41 & -- & -- \\
\hline 09251800 & 9.64 & -- & 9,470 & 30 & 26 & -- \\
\hline 09251900 & 29.3 & -- & 9,010 & 29 & -- & -- \\
\hline
\end{tabular}


Table 7c.--Basin characteristics and channel width--Continued

\begin{tabular}{|c|c|c|c|c|c|c|}
\hline $\begin{array}{l}\text { Station } \\
\text { number }\end{array}$ & $A$ & $S_{B}$ & ELEV & PR & WIDTH & $G_{f}$ \\
\hline 09253000 & 285 & -- & 8,600 & 31 & -- & -- \\
\hline 09253400 & 12.8 & -- & 9,590 & 40 & -- & -- \\
\hline 09254500 & 80.0 & -- & 8,700 & 24 & -- & -- \\
\hline 09255000 & 161 & -- & 8,400 & 22 & -- & -- \\
\hline 09255500 & 200 & -- & 7,790 & 21 & 32 & - \\
\hline 09256000 & 330 & -- & 7,870 & 19 & 54 & -- \\
\hline 09257000 & 988 & -- & 8,030 & 18 & -- & -- \\
\hline 09258000 & 24.0 & -- & 8,200 & 19 & -- & -- \\
\hline 10010400 & 34.6 & -- & 10,500 & 25 & -- & -- \\
\hline 10011500 & 172 & -- & 9,770 & 32 & 69 & -- \\
\hline 10012000 & 59.0 & -- & 9,320 & 24 & 30 & -- \\
\hline 10015700 & 64.0 & -- & 8,050 & 14 & 16 & -- \\
\hline 10019700 & 8.93 & 935 & 7,300 & 12 & -- & -- \\
\hline 10021000 & 56.8 & 1,740 & 7,900 & 26 & -- & -- \\
\hline 10027000 & 246 & 1,160 & 7,270 & 14 & -- & -- \\
\hline 10032000 & 165 & -- & 8,270 & 32 & 47 & -- \\
\hline 10040000 & 45.3 & -- & 7,170 & 19 & -- & -- \\
\hline 10040500 & 37.6 & -- & 7,390 & 23 & -- & -- \\
\hline 10041000 & 113 & -- & 7,290 & 29 & 38 & -- \\
\hline 10047500 & 49.5 & -- & 7,370 & 27 & -- & -- \\
\hline 10058600 & 24.0 & -- & 7,860 & 31 & -- & -- \\
\hline 10069000 & 22.2 & -- & 7,830 & 30 & -- & -- \\
\hline 10128500 & 163 & -- & 9,090 & 32 & -- & -- \\
\hline 13011500 & 169 & -- & 8,160 & 30 & 85 & -- \\
\hline 13011800 & 0.80 & -- & 9,240 & 27 & 9.0 & - \\
\hline 13011900 & 323 & - & 9,270 & 41 & -- & -- \\
\hline 13018300 & 10.6 & -- & 8,430 & 24 & 12 & -- \\
\hline 13019220 & 2.77 & -- & 7,760 & 16 & 3.0 & - \\
\hline 13019400 & 58.6 & -- & 8,200 & 25 & 39 & -- \\
\hline 13019500 & 564 & -- & 8,000 & 24 & 100 & - \\
\hline 13020000 & 46.8 & -- & 7,500 & 25 & 24 & - \\
\hline 13021000 & 8.71 & -- & 7,300 & 25 & 12 & - \\
\hline 13022500 & 3,465 & -- & 8,150 & 25 & $-\overline{-}$ & - \\
\hline 13023000 & 448 & -- & 8,080 & 40 & 95 & - \\
\hline 13023800 & 3.60 & -- & 7,600 & 24 & -- & - \\
\hline 13025500 & 115 & - & 7,420 & 18 & -- & - \\
\hline 13027000 & 21.3 & -- & 8,470 & 25 & 20 & - \\
\hline 13027200 & 3.30 & -- & 7,200 & 27 & -- & - \\
\hline 13029500 & 108 & -- & 6,960 & 24 & - & - \\
\hline 13030000 & 36.8 & -- & 7,790 & 25 & 17 & - \\
\hline 13030500 & 59.2 & -- & 7,670 & 32 & 26 & - \\
\hline 13032000 & 77.1 & -- & 7,130 & 25 & -- & - \\
\hline 13038900 & 20.8 & - & 8,300 & 27 & -- & -- \\
\hline 13050700 & 3.27 & -- & 8,400 & 23 & -- & - \\
\hline 13050800 & 21.4 & -- & 8,300 & 24 & -- & -- \\
\hline 06207540 & 88.0 & 1,140 & 4,520 & 8 & -- & 0.9 \\
\hline 06207800 & 28.1 & 892 & 4,860 & 15 & -- & 0.8 \\
\hline 06226200 & 10.5 & 1,170 & 8,120 & 14 & 11 & 0.8 \\
\hline 06226300 & 97.9 & 1,290 & 7,670 & 14 & 18 & 0.8 \\
\hline 06234800 & 2.39 & 988 & 5,790 & 10 & - & 1.0 \\
\hline
\end{tabular}


Table 7c.--Basin characteristics and channel width--Continued

\begin{tabular}{|c|c|c|c|c|c|c|}
\hline $\begin{array}{l}\text { Station } \\
\text { number }\end{array}$ & $A$ & $S_{B}$ & ELEV & PR & WIDTH & $G_{f}$ \\
\hline \multicolumn{7}{|c|}{ Plains Region } \\
\hline 06235700 & 9.52 & 572 & 5,320 & 8 & 22 & 1.0 \\
\hline 06236000 & 129 & 529 & 5,330 & 8 & 43 & 1.0 \\
\hline 06238760 & 0.69 & 239 & 5,490 & 8 & 6.2 & 1.0 \\
\hline 06238780 & 1.85 & 378 & 5,470 & 8 & -- & 0.8 \\
\hline 06239000 & 733 & - & 5,850 & 8 & -- & 1.0 \\
\hline 06255200 & 4.46 & 792 & 5,620 & 7 & 35 & 1.0 \\
\hline 06255300 & 0.39 & 492 & 5,300 & 7 & - & 1.0 \\
\hline 06255500 & 500 & -- & 6,000 & 8 & -- & 1.0 \\
\hline 06256600 & 7.15 & 1,040 & 6,690 & 10 & -- & 0.8 \\
\hline 06256670 & 5.86 & 526 & 5,450 & 7 & -- & 1.0 \\
\hline 06256700 & 10.0 & 1,060 & 6,580 & 14 & -- & 0.8 \\
\hline 06256800 & 182 & 713 & 6,190 & 12 & -- & 0.8 \\
\hline 06256900 & 52.6 & 1,140 & 6,160 & 11 & 21 & 0.8 \\
\hline 06257000 & 808 & -- & 6,200 & 11 & 120 & 0.9 \\
\hline 06257500 & 267 & 658 & 6,860 & 12 & -- & 0.8 \\
\hline 06258400 & 13.2 & 1,620 & 5,950 & 12 & -- & 0.8 \\
\hline 06260200 & 33.6 & 1,310 & 7,940 & 18 & -- & 1.2 \\
\hline 06265200 & 6.33 & 391 & 5,100 & 10 & 20 & 1.2 \\
\hline 06265600 & 1.78 & 554 & 4,390 & 9 & - & 1.0 \\
\hline 06266320 & 1.30 & 779 & 5,610 & 9 & - & 1.2 \\
\hline 06266460 & 2.32 & 534 & 5,340 & 9 & 10 & 1.2 \\
\hline 06267260 & 3.77 & 773 & 4,420 & 9 & 9.0 & 1.2 \\
\hline 06267270 & 2.11 & 736 & 4,520 & 9 & 6.0 & 1.2 \\
\hline 06267400 & 149 & 491 & 4,600 & 9 & 66 & 1.1 \\
\hline 06268500 & 518 & 671 & 4,940 & 9 & 28 & 1.0 \\
\hline 06274100 & 19.1 & 1,043 & 4,600 & 9 & -- & 1.2 \\
\hline 06274190 & 1.51 & 437 & 4,180 & 7 & 7.0 & 1.0 \\
\hline 06274250 & 96.9 & 691 & 4,300 & 8 & -- & 1.2 \\
\hline 06277700 & 12.8 & 272 & 5,250 & 8 & 17 & 1.0 \\
\hline 06277750 & 0.65 & 622 & 4,920 & 8 & 6.0 & 1.0 \\
\hline 06279020 & 47.8 & 1,240 & 5,500 & 9 & -- & 1.2 \\
\hline 06286258 & 30.1 & 1,440 & 5,570 & 10 & -- & 1.2 \\
\hline 06287500 & 98.3 & 1,000 & 4,240 & 18 & -- & 1.2 \\
\hline 06288200 & 100 & 818 & 4,210 & 15 & -- & 0.9 \\
\hline 06290000 & 111 & 760 & 5,570 & 22 & -- & 1.0 \\
\hline 06291000 & 161 & -- & 4,280 & 15 & -- & 1.0 \\
\hline 06295100 & 34.2 & 647 & 4,650 & 16 & -- & 0.8 \\
\hline 06299900 & 18.0 & 884 & 4,190 & 17 & -- & 1.4 \\
\hline 06306900 & 34.7 & 771 & 4,010 & 14 & -- & 1.4 \\
\hline 06306950 & 4.53 & 936 & 4.240 & 15 & -- & 1.1 \\
\hline 06312700 & 262 & 346 & 6.310 & 11 & 30 & 0.8 \\
\hline 06312910 & 1.53 & 847 & 5,390 & 12 & 11 & 1.6 \\
\hline 06312920 & 1.34 & 1,240 & 5,390 & 12 & -- & 1.6 \\
\hline 06313000 & 1,150 & -- & 5,760 & 11 & 92 & 1.5 \\
\hline 06313020 & 8.29 & 506 & 5,780 & 12 & -- & 1.6 \\
\hline 06313050 & 5.44 & 612 & 5,700 & 12 & 19 & 1.6 \\
\hline 06313100 & 11.4 & 863 & 5,240 & 12 & 43 & 1.6 \\
\hline 06313180 & 0.80 & 794 & 5,040 & 12 & 12 & 1.6 \\
\hline
\end{tabular}


Table 7c.--Basin characteristics and channel width--Continued

\begin{tabular}{|c|c|c|c|c|c|c|}
\hline $\begin{array}{l}\text { Station } \\
\text { number }\end{array}$ & A & $S_{B}$ & ELEV & PR & WIDTH & $G_{f}$ \\
\hline 06313200 & 1.60 & 1,060 & 5,100 & 12 & 13 & 1.6 \\
\hline 06313630 & 10.8 & 1,160 & 4,290 & 12 & 20 & 1.6 \\
\hline 06313700 & 151 & 822 & 4,600 & 13 & 38 & 1.5 \\
\hline 06316480 & 3.32 & 990 & 4,140 & 12 & - & 1.6 \\
\hline 06316700 & 1.64 & 1,490 & 4,080 & 12 & 10 & 1.6 \\
\hline 06317050 & 3.98 & 1,010 & 4,200 & 14 & 7.0 & 1.6 \\
\hline 06319100 & 10.8 & 1,390 & 5,930 & 13 & -- & 1.6 \\
\hline 06324700 & 10.2 & 580 & 3,330 & 14 & -- & 0.8 \\
\hline 06324800 & 0.81 & 988 & 4,320 & 14 & -- & 1.0 \\
\hline 06324900 & 3.45 & 1,020 & 4,300 & 14 & 21 & 1.0 \\
\hline 06324910 & 0.72 & 667 & 4,020 & 14 & 8.0 & 1.0 \\
\hline 06324970 & 1,235 & - & 4,130 & 14 & 27 & 1.0 \\
\hline 06325500 & 1,974 & - & 3,930 & 15 & 30 & 0.9 \\
\hline 06334000 & 904 & - & 3,910 & 16 & 46 & 1.0 \\
\hline 06334100 & 10.1 & 346 & 3,710 & 15 & -- & 1.2 \\
\hline 06334200 & 122 & 193 & 3,690 & 15 & -- & 1.2 \\
\hline 06334500 & 1,970 & -- & 3,700 & 15 & -- & 1.0 \\
\hline 06358550 & 1.57 & 486 & 3,090 & 13 & -- & 1.0 \\
\hline 06358600 & 2.33 & 224 & 3,100 & 13 & -- & 1.0 \\
\hline 06358620 & 0.04 & 625 & 3,100 & 13 & -- & 1.0 \\
\hline 06378640 & 1.20 & 493 & 4,300 & 14 & - & 1.6 \\
\hline 06379600 & 112 & 452 & 5,100 & 12 & -- & 1.2 \\
\hline 06382200 & 5.10 & 743 & 4,400 & 13 & -- & 1.6 \\
\hline 06386000 & 2,070 & -- & 4,670 & 13 & 85 & 1.3 \\
\hline 06386500 & 5,270 & -- & 4,710 & 13 & 120 & 1.5 \\
\hline 06387500 & 47.8 & 451 & 4,400 & 14 & -- & 1.4 \\
\hline 06388800 & 0.25 & 304 & 4,240 & 14 & -- & 1.0 \\
\hline 06394000 & 1,320 & -- & 4,650 & 13 & 24 & 1.2 \\
\hline 06396200 & 0.64 & 157 & 3,800 & 14 & - & 1.0 \\
\hline 06396300 & 0.09 & 933 & 3,760 & 14 & -- & 1.0 \\
\hline 06396350 & 0.20 & 638 & 4,820 & 16 & -- & 1.0 \\
\hline 06399300 & 3.74 & 382 & 3,600 & 14 & -- & 1.0 \\
\hline 06399700 & 7.36 & 329 & 3,500 & 14 & -- & 1.0 \\
\hline 06400000 & 1,044 & -- & 3,900 & 14 & -- & 1.0 \\
\hline 06400900 & 1.52 & 324 & 3,410 & 15 & -- & 1.0 \\
\hline 06404000 & 66.0 & -- & 4,740 & 18 & -- & 1.0 \\
\hline 06406000 & 178 & 263 & 4,500 & 17 & -- & 1.0 \\
\hline 06422500 & 96.0 & -- & 5,400 & 19 & -- & 1.0 \\
\hline 06425720 & 495 & -- & 4,970 & 13 & -- & 1.2 \\
\hline 06426195 & 0.20 & 344 & 4,520 & 14 & -- & 1.4 \\
\hline 06426500 & 1,670 & -- & 4,810 & 13 & 27 & 1.3 \\
\hline 06432200 & 10.3 & 1,340 & 4,400 & 21 & -- & 1.0 \\
\hline 06432230 & 5.23 & 1,440 & 4,200 & 21 & -- & 1.0 \\
\hline 06434800 & 3.06 & 263 & 3,100 & 15 & -- & 1.0 \\
\hline 06436500 & 67.0 & -- & 3,100 & 14 & -- & 1.0 \\
\hline 06436700 & 315 & 250 & 3,300 & 14 & -- & 1.0 \\
\hline 06436770 & 0.20 & 469 & 3,030 & 14 & - & 1.0 \\
\hline 06437100 & 1.32 & 1,150 & 4,900 & 21 & - & 1.0 \\
\hline 06443200 & 7.97 & 1,010 & 4,510 & 17 & -- & 1.0 \\
\hline 06443300 & 10.9 & 1,280 & 4,440 & 17 & -- & 1.0 \\
\hline
\end{tabular}


Table 7c.--Basin characteristics and channel width--Continued

\begin{tabular}{lcccccc}
\hline $\begin{array}{l}\text { Station } \\
\text { number }\end{array}$ & $\mathrm{A}$ & $\mathrm{S}_{\mathrm{B}}$ & ELEV & PR & WIDTH & $\mathrm{G}_{\mathrm{f}}$ \\
\hline 06443700 & 52.6 & -- & 4,530 & 18 & -- & 1.0 \\
06444000 & 313 & -- & 4,550 & 17 & -- & 1.0 \\
06454000 & 400 & -- & 5,080 & 16 & -- & 0.8 \\
06456200 & 3.07 & 331 & 4,360 & 17 & -- & 1.0 \\
06644200 & 2.64 & 927 & 6,140 & 12 & -- & 1.2 \\
06644840 & 2.02 & 643 & 5,850 & 12 & 8.0 & 1.2 \\
06646700 & 2.60 & 1,299 & 5,740 & 14 & -- & 1.0 \\
06648720 & 0.79 & 414 & 5,420 & 12 & -- & 1.0 \\
06648780 & 1.38 & 463 & 5,420 & 12 & -- & 1.0 \\
06649900 & 8.53 & 979 & 5,240 & 14 & 14 & 1.4 \\
06651800 & 27.8 & 301 & 5,000 & 14 & 46 & 1.4 \\
06652400 & 6.95 & 477 & 5,200 & 14 & 7.0 & 1.4 \\
06668040 & 1.30 & 726 & 5,650 & 14 & -- & 1.0 \\
06671000 & 522 & -- & 4,700 & 14 & 15 & 0.8 \\
06675300 & 8.16 & 445 & 6,240 & 16 & -- & 1.0 \\
06677500 & 1,530 & -- & 5,560 & 15 & -- & 0.8 \\
06679000 & 77.2 & -- & 4,240 & 14 & -- & 0.6 \\
06761900 & 0.44 & 115 & 5,300 & 16 & -- & 1.0 \\
06762500 & 1,361 & -- & 5,850 & 16 & -- & 1.0 \\
06762600 & 5.69 & 191 & 5,330 & 16 & -- & 1.0
\end{tabular}

High Desert Region

$\begin{array}{lcrrrrr}06218700 & 4.89 & 1,190 & 7,600 & 12 & 14 & 1.0 \\ 06229700 & 15.4 & 721 & 5,920 & 11 & -- & 1.0 \\ 06233360 & 8.23 & 683 & 5,560 & 12 & 12 & 1.0 \\ 06234700 & 3.88 & 1,170 & 6,370 & 11 & -- & 1.0 \\ 06629150 & 3.65 & -- & 7,100 & 10 & 12 & 1.0 \\ 06629200 & 2.41 & -- & 7,140 & 10 & 7.0 & 1.0 \\ 06629800 & 7.32 & 831 & 7,400 & 10 & 5.8 & 0.8 \\ 06630200 & 7.42 & 342 & 7,030 & 10 & 15 & 1.4 \\ 06631150 & 10.8 & 609 & 7,200 & 12 & 18 & 1.4 \\ 06634600 & 909 & -- & 7,410 & 13 & -- & 1.2 \\ 06634910 & 3.01 & 611 & 6,800 & 10 & 5.0 & 1.4 \\ 06634950 & 1.98 & 846 & 6,930 & 10 & -- & 1.4 \\ 06634990 & 21.6 & -- & 6,980 & 10 & -- & 1.4 \\ 06636500 & 190 & 700 & 7,220 & 12 & -- & 0.8 \\ 06638350 & 6.08 & 859 & 6,810 & 12 & -- & 0.6 \\ 06641400 & 9.33 & 763 & 6,430 & 12 & 13 & 0.8 \\ 06642700 & 11.5 & 1,130 & 6,870 & 12 & 26 & 1.4 \\ 06642730 & 1.34 & 949 & 6,170 & 12 & -- & 1.4 \\ 06642760 & 117 & 913 & 6,800 & 13 & 60 & 1.2 \\ 06643300 & 5.39 & 910 & 5,910 & 14 & 17 & 1.0 \\ 09204700 & 2.77 & 291 & 7,300 & 10 & 8.0 & 0.6 \\ 09207650 & 47.2 & 641 & 7,280 & 12 & -- & 0.6 \\ 09215000 & 500 & 1,021 & 7,270 & 10 & 28 & 0.6 \\ 09216290 & 16.6 & 181 & 6,410 & 7 & 18 & 0.8 \\ 09216350 & 15.7 & 351 & 6,940 & 8 & -- & 0.6 \\ 09216400 & 45.1 & 984 & 7,030 & 9 & -- & 0.6 \\ 09216537 & 32.8 & 530 & 7,040 & 7 & 11 & 1.0\end{array}$


Table 7c.--Basin characteristics and channel width--Continued

\begin{tabular}{lcrlrll}
\hline $\begin{array}{l}\text { Station } \\
\text { number }\end{array}$ & $\mathrm{A}$ & $\mathrm{S}_{\mathrm{B}}$ & ELEV & $\mathrm{PR}$ & WIDTH & $\mathrm{G}_{\mathrm{f}}$ \\
\hline 09216545 & 308 & -- & 7,270 & 8 & -- & 0.6 \\
09216550 & 152 & 507 & 7,000 & 8 & 37 & 0.8 \\
09216560 & 758 & -- & 7,010 & 8 & 25 & 0.8 \\
09216562 & 829 & -- & 7,450 & 8 & -- & 0.6 \\
09216565 & 34.7 & -- & 7,780 & 14 & -- & 0.8 \\
09216580 & 19.5 & 460 & 7,070 & 8 & -- & 0.8 \\
09216600 & 7.88 & 856 & 6,920 & 8 & 10 & 0.8 \\
09216695 & 18.2 & 1,170 & 7,280 & 9 & -- & 0.8 \\
09216700 & 515 & -- & 7,340 & 10 & 48 & 0.9 \\
09216750 & 526 & -- & 7,300 & -- & -- & 0.6 \\
09221680 & 8.83 & 608 & 6,800 & 9 & 16 & 1.0 \\
09222400 & 963 & -- & 7,120 & 11 & -- & 0.8 \\
09224600 & 5.03 & 341 & 6,460 & 8 & 10 & 1.0 \\
09224800 & 5.22 & 127 & 6,370 & 8 & -- & 0.6 \\
09224810 & 12.0 & 561 & 6,650 & 9 & 6.0 & 0.6 \\
09224820 & 3.59 & 662 & 6,570 & 9 & -- & 0.6 \\
09224840 & 1.26 & 862 & 6,570 & 9 & 3.0 & 0.6 \\
09224980 & 423 & 426 & 6,880 & 12 & -- & 1.2 \\
09225200 & 6.57 & 779 & 6,610 & 15 & 15 & 1.2 \\
09225300 & 13.0 & 615 & 6,540 & 16 & 13 & 1.2 \\
09229450 & 3.15 & 968 & 6,600 & 17 & -- & 1.0 \\
09258200 & 49.7 & 462 & 6,950 & 11 & -- & 1.0 \\
09258900 & 1,178 & -- & 7,000 & 12 & 34 & 0.9 \\
& & & & & & \\
\hline
\end{tabular}

